WSRC-TR-98-00279

\title{
Request for One-Time Shipment of 32 Watt PU-328 Source in 9968 Packaging
}

by

W. M. Massey

RECORDS ADMINISTRATION

Westinghouse Savannah River Company

Savannah River Site

Aiken, South Carolina 29808

S. J. Hensel

This paper was prepared in connection with work done under the above contract number with the U.S. Department of Energy. By acceptance of this paper, the publisher and/or recipient acknowledges the U. S. Government's right to retain a nonexclusive, royalty-free license in and to any copyright covering this paper, along with the right to reproduce and to authorize others to reproduce all or part of the copyrighted paper. 
WSRC-TR-98-00279

Equipment Engineering and Systems Department

\section{REQUEST FOR ONE TIME SHIPMENT OF 32 WATT PU-238 SOURCE IN 9968 PACKAGING}

Supplement To

Safety Analysis Report - Packages

USA/9965/B(U)F (DOE-SR)

USA/9966/B(U)F (DOE-SR)

USA/9967/B(U)F (DOE-SR)

USA/9968/B(U)F (DOE-SR)

(Packaging of Fissile and Other Radioactive Materials) DPSPU 83-124-1

S. J. Hensel and W. M. Massey

Westinghouse Savannah River Company

Safety Engineering Department

Aiken, SC 29808

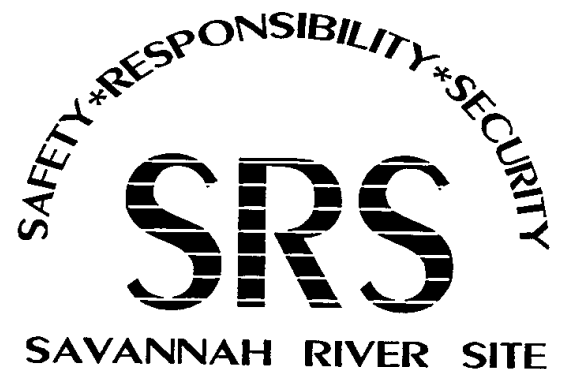




\section{DISCLAIMER}

This report was prepared as an account of work sponsored by an agency of the United States Government. Neither the United States Government nor any agency thereof, nor any of their employees, makes any warranty, express or implied, or assumes any legal liability or responsibility for the accuracy, completeness, or usefulness of any information, apparatus, product, or process disclosed, or represents that its use would not infringe privately owned rights. Reference herein to any specific commercial product, process, or service by trade name, trademark, manufacturer, or otherwise does not necessarily constitute or imply its endorsement, recommendation, or favoring by the United States Government or any agency thereof. The views and opinions of authors expressed herein do not necessarily state or reflect those of the United States Government or any agency thereof.

This report has been reproduced directly from the best available copy.

Available to DOE and DOE contractors from the Office of Scientific and Technical Information, P.O. Box 62, Oak Ridge, TN 37831; prices available from (615) 576-8401.

Available to the public from the National Technical Information Service, U.S. Department of Commerce; 5285 Port Royal Road, Springfield, VA 22161. 
WSRC-TR-98-00279

Engineered Equipment and Systems Department

KEYWORDS: Packaging

Transportation

\title{
REQUEST FOR ONE TIME SHIPMENT OF 32 WATT PU-238 SOURCE IN 9968 PACKAGING
}

\author{
Supplement To \\ Safety Analysis Report - Packages \\ USA/9965/B(U)F (DOE-SR) USA/9966/B(U)F (DOE-SR) \\ USA/9967/B(U)F (DOE-SR) USA/9968/B(U)F (DOE-SR) \\ (Packaging of Fissile and Other Radioactive Materials) \\ DPSPU 83-124-1
}

S. I. Hencel and $\mathrm{W} M$ Maccer 


\section{TABLE OF CONTENTS}

Abstract
Introduction and Background
Chapter 1 General Information
Chapter 2 Structural Evaluation
Chapter 3 Thermal Evaluation
Chapter 4 Containment
Chapter 5 Shielding
Chapter 6 Criticality
Chapter 7 Operating Procedures
Chapter 8 Acceptance Test and Maintenance Program
Chapter 9 Quality Assurance Requirements
Chapter 10 Detail Engineering Drawings
Conclusions and Recommendations
References
Appendices


WSRC-TR-98-00279

Engineered Equipment and Systems Department

\section{ABSTRACT}

The 9968 package is designed for surface shipment of fissile and other radioactive materials where a high degree of double containment is required. The use of the 9968 radioactive material package for a one time shipment of a 32 watt heat source versus the SARP approved maximum 30 watt heat source is addressed in this report. The analyses show that the small increase in heat load from 30 watts to 32 watts does not substantially increase internal temperatures or pressures that would approach limits for the package. Also, the weight of the content is within the current 9968 package limits. It is concluded that the 32-watt heat source can be safely shipped in the 9968 package and therefore a waiver to ship the source is justified. 
WSRC-TR-98-00279

Engineered Equipment and Systems Department

\section{ABBREVIAITIONS}

CFR Code of Federal Regulations

HAC Hypothetical Accident Conditions

MNOP Maximum Normal Operating Pressure

NCT Normal Conditions of Transport

PCV Primary Containment Vessel

QA Quality Assurance

SARP Safety Analysis Report - Packaging

SCV Secondary Containment Vessel

SST Safe, Secure Trailer

TSD Transportation Safeguards Division

WSRC Westinghouse Savannah River Company

WSMS Westinghouse Safety Management Solutions 


\section{INTRODUCTION AND BACKGROUND}

The 9968 package is designed for surface shipment of fissile and other radioactive materials where a high degree of double containment is required. This report contains information and analyses to support shipment of a 32-watt heat source from the Mound Laboratory in Miamisburg, Ohio to the Los Alamos National Laboratory in Los Alamos, New Mexico. The 9968 radioactive material package will be used to ship the heat source. However, the current Safety Analysis Report for Packaging (SARP, Ref. 1) has validated the shipment of heat sources only up to 30 watts. Justification for shipping a 32-watt heat source in the 9968 package is presented in this report. This report is subdivided into the ten chapters corresponding to the $9968 \mathrm{SARP}$ with each chapter describing justification and/or analysis appropriate to confirm that the 9968 is suitable for the 32 watt heat source. Additional thermal and shielding analyses were performed to support the conclusion that the 9968 package could be safely used to transport the encapsulated $\mathrm{Pu}-238$ heat source. 


\section{Chapter 1 General Information}

This supplement to the current 9968 SARP [Ref. 1] evaluates the 9968 package with a $32 \mathrm{~W}$ encapsulated plutonium oxide heat source as contents subject to the regulatory requirements in 10 CFR 71 . The 9968 package and the $32 \mathrm{~W} \mathrm{Pu-238}$ contents will be shipped in the Safe Secure Trailer (SST).

The 9968 package is a Type B double containment and lead shielded drum package ( 35 gallons). The approved contents for the 9968 (based on criticality considerations) are up to $4.4 \mathrm{~kg}$ of plutonium metal or oxides where the Pu- 240 content is equal to or greater than the Pu- 241 content. The approved contents are limited to 30 Watts (based on thermal analysis) and must weigh less than 53 lbs (based on structural analysis).

The Pu-238 source generates 32 Watts of power, is 2 in. in diameter by 1.5 in. high and weighs 497.8 grams. This information was supplied by Mound Laboratory by the correspondence given in Appendix 1 . The isotopic distribution is provided in Table 1.1. The source is primarily Pu-238, and the Pu-240 mass is greater than the Pu-241 mass. The source is completely sealed in a metallic alloy. The source is 22 years old and does not contain any organics internally. The source contains less than 1 gram of moisture (see Appendix 1).

Table 1.1: Isotopic Composition of 32-Watt Source [App. 1]

\begin{tabular}{|l|l|}
\hline Isotope & Mass Fraction (\%) (see note) \\
\hline \hline Pu-238 & 79.5 \\
\hline Pu-239 & 17.2 \\
\hline Pu-240 & 2.59 \\
\hline Pu-241 & 0.54 \\
\hline Pu-242 & 0.14 \\
\hline Am-241 & $3413 \mathrm{ppm}$ \\
\hline Pu-236 & $0.28 \mathrm{ppm}$ \\
\hline
\end{tabular}

Note: The mass fractions do not sum to $100 \%$, the remaining $0.03 \%$ is other materials including the Am- 241 and Pu236.

The exact mass of the Pu isotopes is computed in Table 1.2 based on the total power output of the source. The $\mathrm{PuO}_{2}$ mass is approximately 80.6 grams [(238+32)/238 $\times 71.01 \mathrm{~g} \mathrm{Pu}$. (238 is the molecular weight of $\mathrm{Pu}$ and 32 is the $\mathrm{O}_{2}$ molecular weight)

Table 1.2: Mass of Pu Isotopes

\begin{tabular}{|c|c|c|c|c|}
\hline $\begin{array}{c}\text { (1) } \\
\text { Isotope }\end{array}$ & $\begin{array}{c}(2) \\
\text { Mass Fraction, } \mathrm{g} \\
\text { isotope/g total } \times \\
100(\%)\end{array}$ & $\begin{array}{c}\text { (3) } \\
\text { Specific Power } \\
\text { Isotope (W/g of } \\
\text { isotope) (Ref. 2) }\end{array}$ & $\begin{array}{c}\text { (4) } \\
\text { Specific Power } \\
\text { Source (W/g total } \\
\text { mass) } \\
\text { Col. } 2 \times \text { Col. } 3\end{array}$ & $\begin{array}{c}\text { (5) } \\
\text { Mass Isotope, } \mathrm{g} \\
\text { (Based on } 32 \mathrm{~W} \\
\text { source/0.450518w/ } \\
\text { g), i.e., } \\
71.03 \mathrm{~g} \times \text { Col. } 2\end{array}$ \\
\hline Pu-238 & 79.5 & 0.56602 & 0.449986 & 56.47 \\
\hline Pu-239 & 17.2 & 0.00193 & 0.000332 & 12.22 \\
\hline $\mathrm{Pu}-240$ & 2.59 & 0.00707 & 0.000183 & 1.84 \\
\hline $\mathrm{Pu}-241$ & 0.54 & 0.00313 & 0.000017 & 0.38 \\
\hline $\mathrm{Pu}-242$ & 0.14 & 0.000113 & - - & 0.10 \\
\hline Total Pu & 99.97 & & 0.450518 & 71.01 see note \\
\hline
\end{tabular}

Note: The total mass of heat generating material is determined by $(32 \mathrm{w} / 0.450518 \mathrm{w} / \mathrm{g})=71.03 \mathrm{~g}$ of which $99.97 \%$ is $\mathrm{Pu}$ and $0.03 \%$ is Am-241, Pu-236 and other material. Notice though that $0.28 \mathrm{ppm}$ Pu-236 is equivalent to $\sim 0.00002 \mathrm{~g}$ and $3413 \mathrm{ppm} \mathrm{Am-241}$ is equivalent to $\sim 0.245 \mathrm{~g}$ which is greater than the the $0.0213 \mathrm{~g}$ allowed by the $0.03 \%$ $(0.0003 \times 71.03 \mathrm{~g})$. This is probably attributable to round-off in the analyses. For the shielding analysis, the Am-241 was assumed to be $1 \%$ of the total to bound the contribution to dose. 
The source will be placed in a 7 in. food can ( 7 in. high by 4.25 in. diameter) during shipment (App. 1). The $7 \mathrm{in}$. can will be placed on top of the honeycomb, which rests at the bottom of the primary containment vessel. An additional empty 7 in. can will be placed on top of the 7 in. can containing the source. Both cans will be sealed, however the can lids will have a small hole to ensure equal pressure within the cans and the primary containment vessel. No plastics or other organic materials will be allowed within the primary or secondary containment vessels during shipment. As already mentioned, the Pu-238 contents have 1 gram of moisture or less which is in accordance with the 9968 SARP. Both containment vessels will be closed normally (i.e. no purging or backfilling of any gas will be performed). 
WSRC-TR-98-00279

Engineered Equipment and Systems Department

\section{Chapter 2 Structural Evaluation}

The contents and its shipment in the 9968 package do not require any exemption from limitations described in the structural chapter [Ref. 1]. The MNOP for this shipment is 28.2 psig which is well below the 1,000 psig primary and secondary containment vessel design pressures. The internal gas temperature of the primary containment vessel during NCT is $411^{\circ} \mathrm{F}$ (see Chapter 3) which is below the $500^{\circ} \mathrm{F}$ design temperature for both containment vessels. The peak primary containment vessel temperature during HAC is $436^{\circ} \mathrm{F}$ (Chapter 3 ), which is also below the $500^{\circ} \mathrm{F}$ design temperature. The total mass of the contents including the encapsulated source (497.8 grams), honeycomb (less than 200 grams), and two 7 in. cans (150 grams each) is roughly $1.87 \mathrm{lbs}$ which is well below the $53 \mathrm{lbs}$ limit. 


\section{Chapter 3 Thermal Evaluation}

The primary issue in this supplement is to evaluate the 9968 package (currently certified for 30 Watts) with a 32 Watt content. The Pu-238 source exceeds the certified content power limit by $6.67 \%$ which impacts package temperatures and containment vessel pressures modestly.

The impact on critical packaging component temperatures was determined by conservatively extrapolating package temperatures from the SARP for a 30 Watt content up to the proposed 32 Watt content. These temperatures are well below acceptance criteria. Details of the extrapolation are documented in Appendix 2. Details of the containment vessel pressure analysis are given below.

The free volume within the containment vessels (primary and secondary) are required to determine the operating pressures of the package. The vessel volumes in column 2 of Table 3.1 are taken directly from the 9968 SARP [Ref. 1, pgs. 3-25,26]. The SARP uses conservatively low values for this volume to overestimate the vessel pressure. The actual total free volume was estimated and is provided in column 3 , and the actual net free volume (column 5) subtracts the volume of the sealed Pu source. Note that the SCV free volume is based on the PCV being within the SCV (the SCV total free volume is the sum of the PCV free volume and the volume between the PCV and SCV). The values in Table 3.1 illustrate the conservative (i.e. small) free volume used in the SARP. These conservative volumes for the containment vessels are used in this supplement to maintain consistency.

Table 3.1: Vessel volumes

\begin{tabular}{|l|l|l|l|l|}
\hline Vessel & \multicolumn{1}{|c|}{ SARP Vol. (ft. $\left.{ }^{3}\right)$} & \multicolumn{1}{|c|}{$\begin{array}{c}\text { Total Free Vol. } \\
\left(\mathrm{ft}^{3}{ }^{3}\right.\end{array}$} & $\begin{array}{c}\text { Content Vol. } \\
\left(\mathrm{ft.}^{3}\right)\end{array}$ & $\begin{array}{c}\text { Actual Net Free } \\
\text { Vol. }\left(\mathrm{ft}^{3}\right)\end{array}$ \\
\hline \hline PCV & $0.1227^{1}$ & $0.1814^{2}$ & $.00273^{3}$ & 0.1787 \\
\hline SCV & $0.2231^{4}$ & $0.2817^{5}$ & $.00273^{3}$ & 0.2790 \\
\hline
\end{tabular}

Conservative volume used in Reference 1 to calculate maximum pressure in PCV $\left(3475 \mathrm{cc} \equiv 0.1227 \mathrm{ft}^{3}\right)$

Actual PCV volume from Reference $1\left(313.4 \mathrm{in}^{3} \equiv 0.1814 \mathrm{ft}^{3}\right)$

Calculated from dimensions in Appendix $1\left(\pi \times(2 / 12)^{2 / 4} \times 1.5 / 12=0.00273 \mathrm{ft}^{3}\right)$

Calculated from Reference 1 PCV volume + SCV volume with PCV inside SCV $(3475 \mathrm{cc}+2842 \mathrm{cc}=6317 \mathrm{cc}$ or $0.2231 \mathrm{ft}^{3}$ )

5 Calculated from total SCV volume $\left(604.4\right.$ in $^{3} \equiv 0.3498 \mathrm{ft}^{3}$, Ref.1) less metal volume of PCV. Metal volume of PCV determined approximately from weight of PCV (33.6 lbs, Ref. 1) and density of 304 SS (Ref. 5, 493.3 $1 \mathrm{~b} / \mathrm{ft}^{3}$ ) to be $0.0681 \mathrm{ft}^{3}$. Total free volume $=0.3498-0.0681=0.2817 \mathrm{ft}^{3}$.

The only gas species within the package containment vessels is air. However, assuming the sealed source ruptures during shipment, helium and hydrogen (from complete radiolysis of water) would also be present in the containment vessels. Total number of moles of gas in the vessels is provided in Table 3.2. These values are determined using the ideal gas law as follows (Ref. 2):

$M=\frac{P \times V}{R \times T}$

where:

$\mathrm{M}=$ number of $\mathrm{lb}$-moles

$\mathrm{P}=$ pressure in psia

$\mathrm{R}=10.73$, universal gas constant, psia- $\mathrm{ft}^{3} /{ }^{\circ} \mathrm{R}$ lb-mole (Ref. 2 )

$\mathrm{T}=$ Temperature in ${ }^{\circ} \mathrm{R}$

$\mathrm{V}=$ Volume in $\mathrm{ft}^{3}$ 
WSRC-TR-98-00279

Engineered Equipment and Systems Department

Table 3.2: Gas Species In Containment Vessels (assuming Pu source ruptures)

\begin{tabular}{|l|c|c|c|c|}
\hline Vessel & $\begin{array}{c}\text { Air (lb.-moles) } \\
\text { (based on SARP } \\
\text { free volumes and } \\
70^{\circ} \mathrm{F} \text { ambient) }\end{array}$ & $\begin{array}{c}\text { Helium (lb.-moles) } \\
\text { (based on 32 } \\
\text { Watts for 30 yrs. } \\
\text { vs. actual 22 yrs.) }\end{array}$ & $\begin{array}{c}\text { Hydrogen (lb.- } \\
\text { moles) (based on } \\
1 \text { gram moisture } \\
\text { and } 81 \mathrm{~g} \mathrm{PuO}_{2} \text { ) }\end{array}$ & $\begin{array}{c}\text { Total Gas } \\
\text { (lb.-moles) }\end{array}$ \\
\hline \hline PCV & 0.000317 & $0.000123^{1}$ & $0.000121^{2}$ & 0.000562 \\
\hline SCV & 0.000577 & $0.000123^{1}$ & $0.000121^{2}$ & $\begin{array}{c}0.000821 \\
\text { (assuming PCV } \\
\text { leakage) }\end{array}$ \\
\hline
\end{tabular}

1 Based on generation of $0.0035 \mathrm{~g}$-mole helium in 2 yrs. scaled up to 30 yrs. from Ref. 1 (pg. 3-25) and for increased heat load $(32 / 30)$ and conversion to lbs. $\left(0.0035^{*} 32 / 30^{*} 15 / 453.6=0.000123 \mathrm{lb}\right.$-moles $)$

2 Based on $0.055 \mathrm{~g}$-mole from Ref. 1, pg. 3-25 converted to lb-mole $(0.055 / 453.6=\mathrm{lb}$-moles $)$

The pressures during NCT are computed and presented in Table 3.3. The temperature is based on linear extrapolation of the $9965 \mathrm{PCV}$ gas temperature $\left(395^{\circ} \mathrm{F}\right.$ for 30 watts of contents) up to a 32 watt content [pg. 3-25, Ref. 1]. (The 9965 gas temperature is higher than the 9968 and therefore is used here for conservatism as was done in Reference 1.) The extrapolated temperature is conservatively used for the SCV pressures, too. The pressures are well below the 1000 psig design pressure. The gas species include air, helium and hydrogen as presented in Table 3.2. The Maximum Normal Operating Pressure listed in the SARP is 34 psia (shown as $34 \mathrm{psig}$ by typographical error). The PCV pressure in Table 3.3 is 42.9 psia which is above the SARP MNOP of 34 psia but well below the design pressure. These pressures are calculated using the ideal gas law as follows:

$$
P=\frac{M \times R \times T}{V}
$$

where the symbols are as defined above and the parameters are given in the table.

Table 3.3: NCT Pressures

\begin{tabular}{ll|l|l|l|l|l|}
\hline Vessel & \multicolumn{1}{|c|}{$\begin{array}{c}\text { Temperature } \\
\left({ }^{\circ} \mathrm{F}\right)\end{array}$} & \multicolumn{1}{|c|}{ Volume (ft. $\left.{ }^{3}\right)$} & Gas (lb.-moles) & $\begin{array}{c}\text { Gas Constant } \\
\left(\mathrm{psi}-\mathrm{ft}^{3} /{ }^{\circ} \mathrm{R}-\mathrm{lb} .-\right. \\
\mathrm{moles})\end{array}$ & Pressure (psia) \\
\hline \hline PCV & $411^{1}$ & $0.1227^{2}$ & $0.000562^{3}$ & $10.73^{4}$ & 42.8 \\
\hline SCV & $411^{1}$ & $0.2231^{2}$ & $0.000821^{3}$ & $10.73^{4}$ & 34.4 \\
\hline
\end{tabular}$\quad \begin{aligned} & \text { Temperature calculated via linear extrapolation from } 395^{\circ} \mathrm{F} \text { using ratio of source powers }(395-150)^{*} 32 / 30+150 \\
& \quad=411^{\circ} \mathrm{F} \\
& 2 \quad \text { Table 3.1 } \\
& 3 \quad \text { Table 3.2 } \\
& 4 \quad \text { Reference 3 }\end{aligned}$

The pressures during HAC are computed and presented in Table 3.4. The temperature is based on linear extrapolation of the $9966 \mathrm{PCV}$ gas temperature $\left(478^{\circ} \mathrm{F}\right.$ for 30 watts of contents, $100^{\circ} \mathrm{F}$ ambient temperature) up to a 32 watt content [pg. 3-34, Ref. 1]. (The 9966 gas temperature is higher than the 9968 and therefore is used here for conservatism as was done in Reference 1.) The extrapolated temperature is conservatively used for the SCV pressures, too. The peak containment vessel pressures during the hypothetical accident fire are well below the 1000 psig design pressure for the containment vessels. The gas species include air, helium and hydrogen as presented in Table 3.2. 
WSRC-TR-98-00279

Engineered Equipment and Systems Department

Table 3.4: HAC Pressures

\begin{tabular}{|c|c|c|c|c|c|c|}
\hline & Vessel & $\begin{array}{c}\text { Temperature } \\
\left({ }^{\circ} \mathrm{F}\right)\end{array}$ & Volume $\left(\mathrm{ft}^{3}{ }^{3}\right)$ & $\begin{array}{c}\text { Total Gas (lb.- } \\
\text { moles) }\end{array}$ & $\begin{array}{l}\text { Gas Constant } \\
\text { (psi-ft. }{ }^{3} / 0 \mathrm{R}-\mathrm{lb} .- \\
\text { moles) }\end{array}$ & Pressure (psia) \\
\hline $\mathrm{PC}$ & & $503^{1}$ & $0.1227^{2}$ & $0.000562^{3}$ & $10.73^{4}$ & 47.3 \\
\hline $\mathrm{SC}$ & & $503^{1}$ & $0.2231^{2}$ & $0.000821^{3}$ & $10.73^{4}$ & 38.0 \\
\hline \multicolumn{7}{|c|}{$\begin{array}{l}\text { Temperature calculated via linear extrapolation from } 478^{\circ} \mathrm{F} \text { using ratio of source powers }(478-100)^{*} 32 / 30+100 \\
=503^{\circ} \mathrm{F}\end{array}$} \\
\hline \multicolumn{7}{|c|}{ Table 3.1} \\
\hline \multicolumn{7}{|c|}{$3 \quad$ Table 3.2} \\
\hline \multicolumn{7}{|c|}{ Reference 3} \\
\hline
\end{tabular}

During HAC the SARP reports a primary containment vessel peak metal temperature of $415^{\circ} \mathrm{F}$ and a peak internal gas temperature of $478^{\circ} \mathrm{F}$ [pg. 3-34,35, Ref. 1]. Assuming a similar temperature gradient exists with the $32 \mathrm{~W}$ contents, the peak primary containment vessel (metal) temperature during $\mathrm{HAC}$ is $436^{\circ} \mathrm{F}$ $[(415-100) * 32 / 30+100]$, which is well below the $500^{\circ} \mathrm{F}$ containment vessel design temperature. 
WSRC-TR-98-00279

Engineered Equipment and Systems Department

\section{Chapter 4 Containment}

The containment section of the SARP is not impacted by the Pu-238 source as contents. The "Viton" GLT O-rings are serviceable up to $500^{\circ} \mathrm{F}$ [Ref. 1] which is well above the $411^{\circ} \mathrm{F}$ internal temperature of the primary containment vessel during NCT and the peak primary containment vessel temperature of $436^{\circ} \mathrm{F}$ during HAC.

As already mentioned, the contents are confined in a single $7 \mathrm{in}$. tall food can. The lid of the food can will be punctured prior to sealing the can to ensure no pressurization within the food can. An empty 7 in. tall food can will be stacked above and its lid will also be punctured. No plastics or organics will be in the primary or secondary containment vessel during shipment other than the "Viton" GLC O-rings used to seal the 9968 containment vessels. 
WSRC-TR-98-00279

Engineered Equipment and Systems Department

\section{Chapter 5 Shielding}

The shielding chapter in the 9968 SARP contains an evaluation of weapons grade Pu metal only. The gamma and neutron source from the Pu-238 oxide contents is sufficiently different to require further evaluation. A very detailed shielding analysis, including a Pu-238 oxide content, was performed [Ref. 4, included as Appendix 3]. These results are summarized in this chapter.

The Pu-238 oxide content considered for shielding purposes is defined in Table 5.1.

Table 5.1 : Content Analyzed In Detailed Shielding Analyses

\begin{tabular}{|l|l|}
\hline Isotopes & Weight Percent \\
\hline \hline Am-241 & 1.00000 \\
\hline Am-243 & 0.00010 \\
\hline $\mathrm{Cm}-244$ & 0.00010 \\
\hline $\mathrm{Np}-237$ & 0.50000 \\
\hline $\mathrm{Pu}-236$ & 0.00010 \\
\hline $\mathrm{Pu}-238$ & 100.000 \\
\hline $\mathrm{Pu}-239$ & 40.0000 \\
\hline $\mathrm{Pu}-240$ & 13.0000 \\
\hline $\mathrm{Pu}-241$ & 1.00000 \\
\hline $\mathrm{Pu}-242$ & 1.50000 \\
\hline Th-232 & 10.0000 \\
\hline $\mathrm{U}$ & 1.00000 \\
\hline
\end{tabular}

The restricting limit for this content is 100 grams. That is, the maximum mass of each isotope as defined by this content is equal to its permitted weight percentage in grams where the total content mass of the isotopes defined in Table 5.1 is no greater than 100 grams.

For conservatism decay transmutations were evaluated over 100 years beginning with the content distribution. The maximum isotopic activities calculated during the 100 years of decay were then used to calculate the source distribution to determine the most conservative doses.

A summary of the shielding results is presented in Table 5.2 along with the regulatory limits. The objective of this evaluation is to demonstrate compliance with the performance requirements specified in $10 \mathrm{CFR}$ 71.47, 10 CFR 71.57, 49 CFR 173.403, and 49 CFR 173.441 for each package and its contents. According to these regulations, dose rate limits are $200 \mathrm{mrem} / \mathrm{h}$ at the accessible surface of the package, $10 \mathrm{mrem} / \mathrm{h}$ at $1 \mathrm{~m}$ from the accessible surface of the package, and $1000 \mathrm{mrem} / \mathrm{h}$ at $1 \mathrm{~m}$ from the surface of a damaged package after a hypothetical accident. The shielding analysis results indicate that the 9968 package complies (with a significant margin of safety) with the federal regulations for nonexclusive use. 
WSRC-TR-98-00279

Engineered Equipment and Systems Department

Table 5.2: Shielding Results

\begin{tabular}{|c|c|c|}
\hline NCT Surface & Dose (mrem/hr) & 10 CFR 71 Limits (mrem/hr) \\
\hline $\begin{array}{l}\text { SIDE } \\
\text { Neutrons } \\
\text { Photons } \\
\text { Total } \\
\end{array}$ & $\begin{array}{l}73.3 \\
13.6 \\
86.9 \\
\end{array}$ & 200.0 \\
\hline $\begin{array}{l}\text { TOP } \\
\text { Neutrons } \\
\text { Photons } \\
\text { Total }\end{array}$ & $\begin{array}{l}21.3 \\
2.47 \\
23.8\end{array}$ & 200.0 \\
\hline $\begin{array}{l}\text { BOTTOM } \\
\text { Neutrons } \\
\text { Photons } \\
\text { Total } \\
\end{array}$ & $\begin{array}{l}55.9 \\
25.5 \\
81.4 \\
\end{array}$ & 200.0 \\
\hline NCT $1 \mathrm{~m}$ Away & & \\
\hline $\begin{array}{l}\text { SIDE } \\
\text { Neutrons } \\
\text { Photons } \\
\text { Total } \\
\end{array}$ & $\begin{array}{c}1.75 \\
0.431 \\
2.18 \\
\end{array}$ & 10.0 \\
\hline $\begin{array}{l}\text { TOP } \\
\text { Neutrons } \\
\text { Photons } \\
\text { Total }\end{array}$ & $\begin{array}{l}0.754 \\
0.115 \\
0.869\end{array}$ & 10.0 \\
\hline $\begin{array}{l}\text { BOTTOM } \\
\text { Neutrons } \\
\text { Photons } \\
\text { Total } \\
\end{array}$ & $\begin{array}{c}1.47 \\
0.715 \\
2.19 \\
\end{array}$ & 10.0 \\
\hline HAC 1 m Away & & \\
\hline $\begin{array}{l}\text { SIDE } \\
\text { Neutrons } \\
\text { Photons } \\
\text { Total } \\
\end{array}$ & $\begin{array}{c}2.29 \\
4.54 \\
3.0 \\
\end{array}$ & 1000.0 \\
\hline $\begin{array}{l}\text { TOP } \\
\text { Neutrons } \\
\text { Photons } \\
\text { Total }\end{array}$ & $\begin{array}{l}0.713 \\
0.168 \\
0.881\end{array}$ & 1000.0 \\
\hline $\begin{array}{l}\text { BOTTOM } \\
\text { Neutrons } \\
\text { Photons } \\
\text { Total } \\
\end{array}$ & $\begin{array}{l}1.89 \\
3.35 \\
5.24 \\
\end{array}$ & 1000.0 \\
\hline
\end{tabular}


WSRC-TR-98-00279

Engineered Equipment and Systems Department

\section{Chapter 6 Criticality}

The $32 \mathrm{~W}$ source term contains $\sim 71$ grams of Plutonium and the Pu-240 contents are greater than the Pu241 contents (see $\mathrm{Ch} .1$ ). The SARP establishes an approved contents of $4.4 \mathrm{~kg}$ of Pu (where Pu-240 contents are equal to or greater than Pu-241 contents) based on criticality considerations which envelopes the $32 \mathrm{~W}$ source term. Therefore no further evaluation is required. 
WSRC-TR-98-00279

Engineered Equipment and Systems Department

Chapter 7 Operating Procedures

The operating procedures chapter in the 9968 SARP are applicable to the operations of the $32 \mathrm{~W}$ source with the following modifications and additions.

1. The $32 \mathrm{~W}$ source will not be placed in a plastic bag.

2. The $32 \mathrm{~W}$ source will not be enclosed in a inner product can.

3. The $32 \mathrm{~W}$ source will be shipped in the DOE Transportation Safeguards Division (TSD) Safe, Secure Trailer (SST).

4. Two 7 inch tall food cans will be shipped in the PCV. The cans will be stacked and the lids of both will be punctured. The top can will be empty and the 32 watt source will be shipped within the bottom can.

5. No filler or other materials will be allowed in the PCV or SCV during shipment except the honeycomb specified on drawings. 
WSRC-TR-98-00279

Engineered Equipment and Systems Department

\section{Chapter 8 Acceptance Test and Maintenance Program}

In chapters 1-7 the use of a $32 \mathrm{~W}$ heat source has been shown to fit well within the safety envelope of the 9968 packaging as originally conceived, designed and built. Therefore, the acceptance test and maintenance program established for the 9968 packaging requires no modifications or additions to accommodate the $32 \mathrm{~W}$ source. 
WSRC-TR-98-00279

Engineered Equipment and Systems Department

Chapter 9 Quality Assurance Requirements

The $32 \mathrm{~W}$ heat source presents no additional hazard or usage restrictions as demonstrated in chapters 1-8 that would alter the safety related or "Q" items for the 9968 packaging. No changes to Chapter 9 are required except to note that current $\mathrm{QA}$ site related administrative requirements are to be implemented as required. 
WSRC-TR-98-00279

Engineered Equipment and_Systems Department

\section{Chapter 10 Detail Engineering Drawings}

There are no design changes associated with using the $32 \mathrm{~W}$ heat source and therefore there are no revisions or additions to the engineering drawings. 
WSRC-TR-98-00279

Engineered Equipment and Systems Department

\section{CONCLUSIONS AND RECOMMENDATIONS}

The 9968 radioactive material package is shown to be capable for transporting a 32 watt heat source. The additional thermal load does not increase the internal temperatures or pressures significantly. These parameters are well below the package limits as described in Reference 1 under NCT or HAC. The shielding is also shown to adequate to meet regulatory guidelines.

It is recommended that the 9968 package be used for transportation of the 32 watt heat source. 


\section{REFERENCES}

1. Safety Analysis Report - Packages, USA/9965B(U)F (DOE-SR), USA/9966B(U)F (DOE-SR), USA/9967B(U)F (DOE-SR), USA/9968B(U)F (DOE-SR), Packaging of Fissile and Other Radioactive Materials, Final Report, DPSPU 83-124-1, DuPont, June, 1984.

2. "Fission Product Production at SRS", EPD-CTG-94-0039, R. L. Webb, WSRC, Dec. 1994.

3. "Thermodynamics", $5^{\text {th }}$ edition, Kenneth Wark, McGraw-Hill, Inc.

4. "Dose Calculation for Pu-238 Oxide Payload in 9968 Shipping Container", N-CLC-G-00067, R. L. Webb, WSMS, July, 1998.

5. "Fundamentals of Heat and Mass Transfer", $4^{\text {th }}$ edition, Incropera and DeWitt, John Wiley \& Sons. 
WSRC-TR-98-00279

Engineered Equipment and Systems Department

\section{APPENDICES}

1. 32 Watt Source Information Communication from Mound Laboratory

2. Thermal Calculations for 9968 Package with 32 Watt Heat Source

3. Dose Calculation for Pu-238 Oxide Payload in 9968 Shipping Container 
WSRC-TR-98-00279

Engineered Equipment and Systems Department

APPENDIX 1

32 Watt Source Information Communication from Mound Laboratory 
WSRC-TR-98-00279

Engineered Equipment and Systems Department

\section{BWX Technologies, Inc.}

Babcock \& Wilcox of Ohio, Inc.

WM-112/98

July 28,1998

1 Mound Road
P.O. Box 3030
Miamisburg, Ohio 45343-3030
(937) 865-4020

Mr. William Massey

Westinghouse Savannah River Company

Savannah River Site

Aiken, SC 29801

\section{SUBJECT: Contract No. DE-AC24-97OH20044 9968 Exemption Request}

Dear Mr. Massey:

In support of Mound's request for a one time shipment of the 32 watt heat source, the following information provided is a summary of data previously supplied to SRS via e-mail:

- the power of the source is 32 watts

- the dimensions of the source are $2^{\prime \prime}$ dia. $X 1.5^{\prime \prime}$ high

- gross weight of the source is 497.8 grams

- the isotopic distribution is:

$\begin{array}{lll}\text { Pu-238 } & 79.5 \% & \text { (Weight \%) } \\ \text { Pu-239 } & 17.2 \\ \text { Pu-240 } & 2.59 \\ \text { Pu-241 } & 0.54 \\ \text { Pu-242 } & 0.14 \\ \text { Pu-236 } & 0.28 \text { ppm } \\ \text { Am-241 } & 3413 \text { ppm }\end{array}$

- the materials of encapsulation are unknown

- the source is approximately 22 years old

- based upon process knowledge, the moisture content of the source is less than one gram

If you need additional information, please call Jerry Crawford at (937) 865-3172.

Sincerely,

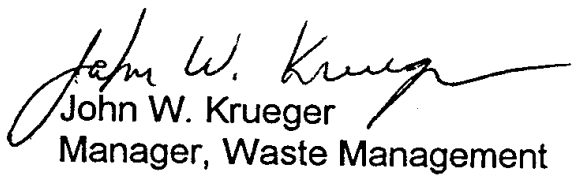

cc: Jerry Crawford

Ray Finney 
WSRC-TR-98-00279

Engineered Equipment and Systems Department

\section{APPENDIX 2}

Thermal Calculations for 9968 Package with 32 Watt Heat Source 
WSRC-TR-98-00279

Engineered Equipment and Systems Department

\section{Calculation Cover Sheet}

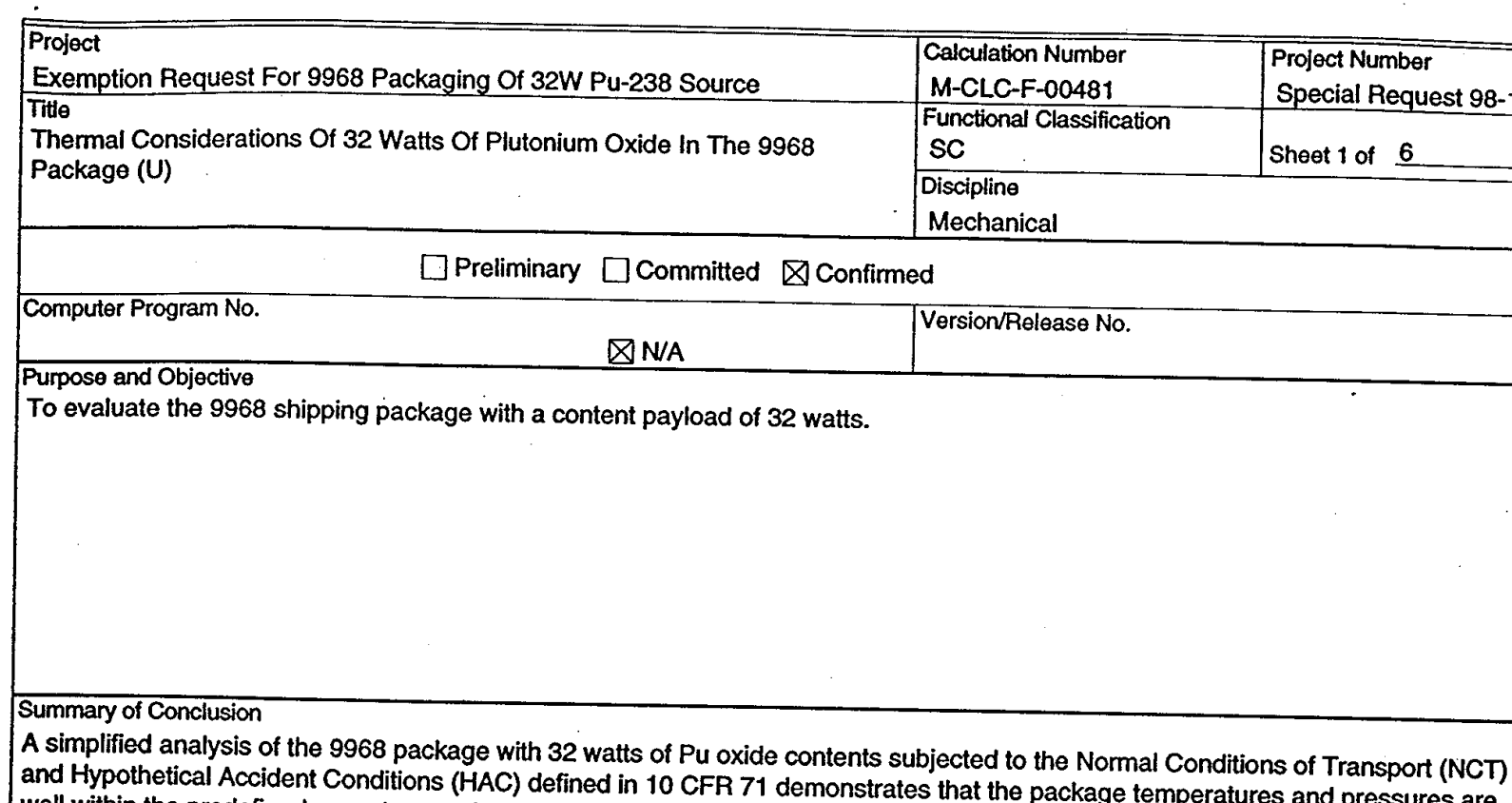

well within the predefined acceptance criteria in the 9968 SARP.

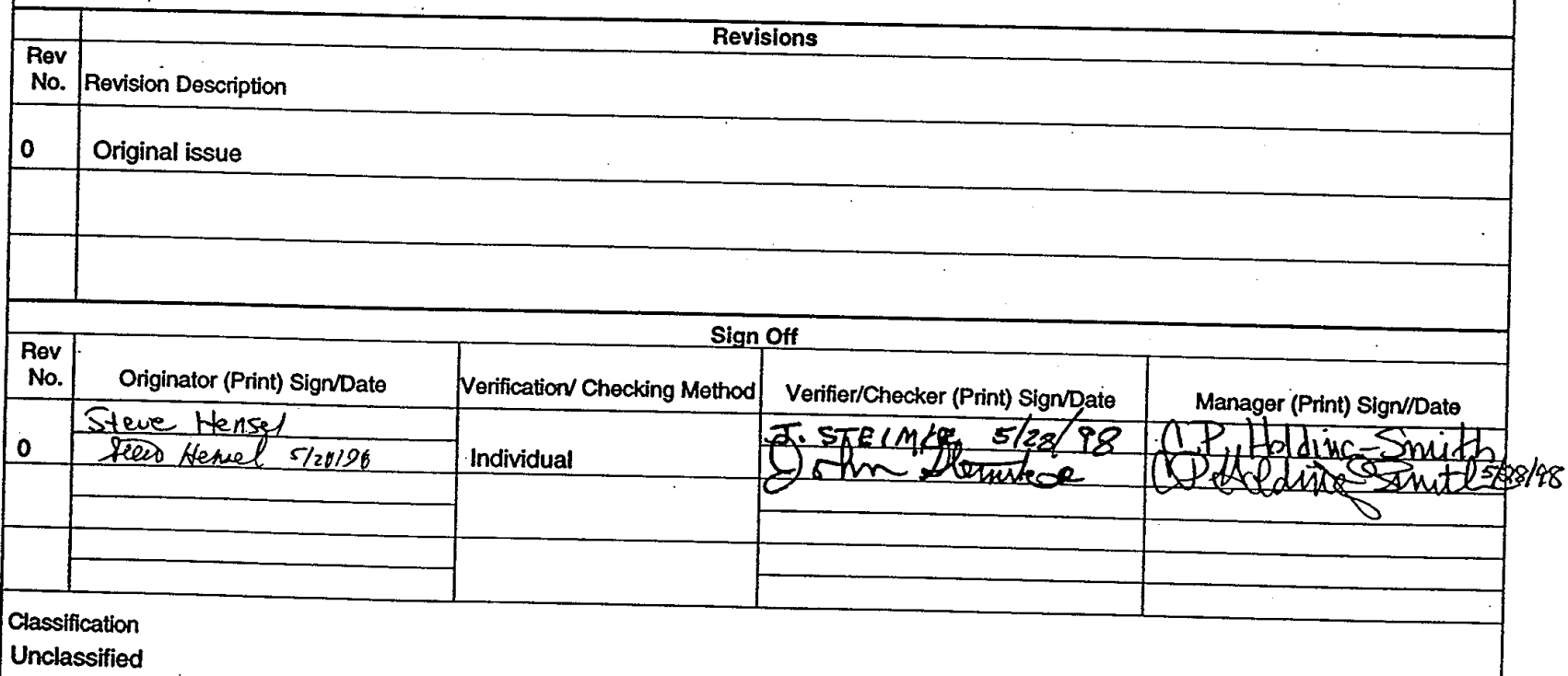


M-CLC-F-00481, Rev. 0

P. 2 of 6

\section{Thermal Considerations Of 32 Watts Of Plutonium Oxide In The 9968 Package}

\subsection{Conclusions}

A simplified analysis of the 9968 package with 32 watts of $\mathrm{Pu}$ oxide contents subjected to the Normal Conditions Of Transport (NCT) and Hypothetical Accident Conditions (HAC) defined in 10 CFR 71 demonstrates that the package temperatures and pressures are well within the predefined acceptance criteria in the SARP [1].

\subsection{Input}

The thermal chapter (Chapter 3) of the 9968 SARP provides temperatures and pressure within the packaging for a 30 watt plutonium payload during NCT [1]. These values are provided in Table 1.

Table 1: Current Performance Of The 9968 Package During NCT ( 30 watt payload)

\begin{tabular}{|l|l|}
\hline Location & Temperature ( $\mathrm{F}$ )/Pressure (psig) \\
\hline \hline ambient temperature & 150 \\
\hline outside drum temperature & 150 \\
\hline midpoint of insulation temperature & 179 \\
\hline lead shield temperature & 201 \\
\hline SCV temperature & 223 \\
\hline PCV temperature & 260 \\
\hline upper button temperature & 438 \\
\hline lower button temperature & 419 \\
\hline $\begin{array}{l}\text { Maximum Normal Operating Pressure } \\
\text { (based on 9965) }\end{array}$ & 34 (based on $395^{\circ} \mathrm{F}$ gas temperature) \\
\hline
\end{tabular}

Similarly, Table 2 contains the 9968 SARP temperatures and pressure for the HAC with 30 watts of plutonium contents. The temperature and pressure acceptance criteria in the 9968 SARP for each component are provided in Table 3. These acceptance criteria must be satisfied to ensure package safety and demonstrate compliance with 10 CFR 71 requirements. 
M-CLC-F-00481, Rev. 0

P. 3 of 6

Table 2: Current Performance Of The 9968 Package During HAC ( 30 watt payload)

\begin{tabular}{|l|l|}
\hline Location & Temperature ( $\mathrm{F}) /$ Pressure (psig) \\
\hline \hline ambient temperature before and after fire & 100 \\
\hline ambient temperature during fire & 1475 \\
\hline peak lead shield temperature & 318 \\
\hline peak SCV temperature & 330 \\
\hline peak PCV temperature & 362 \\
\hline peak PCV pressure (based on 9966) & 37 (based on $478^{\circ} \mathrm{F}$ gas temperature) \\
\hline
\end{tabular}

Table 3: Acceptance Criteria From 9968 SARP For Critical Components

\begin{tabular}{|c|c|c|}
\hline Component & $\begin{array}{l}\text { NCT } \\
\text { Temp. }\left({ }^{\circ} \mathrm{F}\right) / \text { Pressure (psig) }\end{array}$ & $\begin{array}{l}\text { HAC } \\
\text { Temp. (F)/Pressure (psig) }\end{array}$ \\
\hline O-rings & $500 / 1000$ & $500 / 1000$ \\
\hline $\mathrm{PCV}$ & $500 / 1000$ & $500 / 1000$ \\
\hline SCV & $500 / 1000$ & $500 / 1000$ \\
\hline Fiberboard & $325 / \mathrm{NA}$ & NA / NA \\
\hline Lead & 621/NA & $621 / \mathrm{NA}$ \\
\hline
\end{tabular}

\subsection{Analytical Methods and Computations}

The temperatures and pressures in Tables 1 and 2, which are based on 30 watt contents, can be readily scaled up to account for a 32 watt content. The scaling is a linear extrapolation based on the generic steady-state heat conduction equation below.

where:

$$
T_{i}=T_{0}+Q R_{1}
$$

$\mathrm{T}_{\mathrm{i}}$ is the temperature at $\mathrm{i}\left({ }^{\circ} \mathrm{F}\right)$

$T_{0}$ is the reference temperature with zero watts contents

$Q$ is internal heat generation in watts

$R_{i}$ is the thermal resistance from location $i$ to the ambient 
The $150^{\circ} \mathrm{F}$ ambient NCT temperature is described in the SARP as the non-solar ambient equivalent to the NCT solar conditions, and this temperature is used as the reference temperature in the extrapolation equation.

During HAC, the temperature rise in the package is attributable to both the 30 minute fire and decay heat from the contents. In scaling the temperatures during HAC due to increased content heat generation, a reasonable approach would be to add the increase in steady-state NCT temperatures at each location $i$ in going from 30 to 32 watts to the peak HAC temperatures for 30 watts. As shown in Figure 1, thermal analyses of drum overpack designs have shown that the temperature rise of the containment vessel during the HAC fire is virtually independent of content heat generation for contents generating between 25 and 50 watts [2]. The peak temperatures during HAC are essentially the initial temperature (NCT without solar) plus a rise due to the fire. The HAC temperatures for 32 watts are computed by adding the increase in NCT temperatures in going from 30 to 32 watts to the 30 watt HAC values. This approach is especially valid when dealing with small wattage changes (less than 10\%).

\subsection{Results}

The temperatures and pressures for NCT and HAC are scaled upward for a 32 watt content and presented in Tables 4 and 5. Extrapolated temperatures and pressures during NCT and HAC for the critical packaging components are well below the acceptance criteria listed in Table 3. Therefore, the 9968 package can safely transport 32 watts of plutonium contents while satisfying the requirements of $10 \mathrm{CFR} 71$. 
WSRC-TR-98-00279

Engineered Equipment and Systems Department

M-CLC-F-00481, Rev. 0

P. 5 of 6

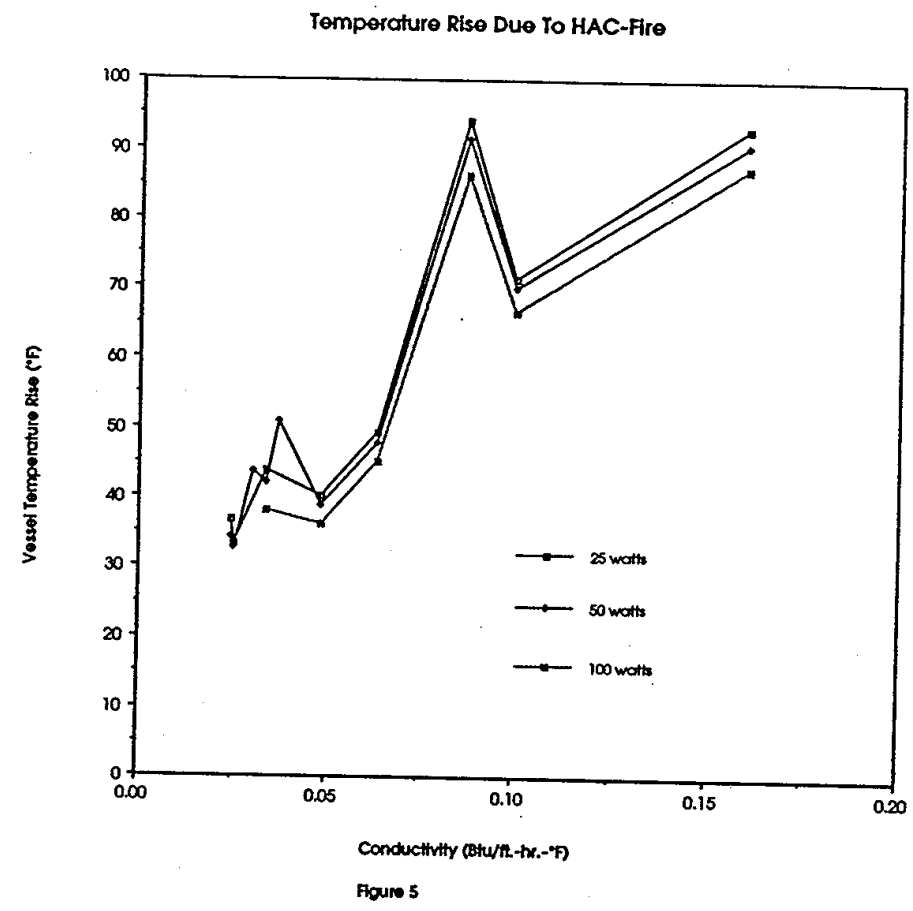

Figure 1 (taken directly from ref. 2)

Table 4: Extrapolated Performance Of The 9968 Package During NCT (32 watt payload)

\begin{tabular}{|l|l|}
\hline Location & Temperature (F)/Pressure (psig) \\
\hline \hline ambient temperature & 150 \\
\hline outside drum temperature & 150 \\
\hline midpoint of insulation temperature & 181 \\
\hline lead shield temperature & 204 \\
\hline SCV temperature & 228 \\
\hline PCV temperature & 267 \\
\hline upper button temperature & 457 \\
\hline lower button temperature & 437 \\
\hline $\begin{array}{l}\text { Maximum Normal Operating Pressure } \\
\text { (based on 9965) }\end{array}$ & 35 (based on $411^{\circ} \mathrm{F}$ gas temperature) \\
\hline
\end{tabular}


Table 5: Extrapolated Performance Of The 9968 Package During HAC (32 watt payload)

\begin{tabular}{|l|l|}
\hline Location & Temperature $\left({ }^{\circ} \mathrm{F}\right) /$ Pressure (psig) \\
\hline \hline ambient temperature before and after fire & 100 \\
\hline ambient temperature during fire & 1475 \\
\hline peak lead shield temperature & 332 \\
\hline peak SCV temperature & 345 \\
\hline peak PCV temperature & 379 \\
\hline peak PCV pressure (based on 9966$)$ & 37 (based on $503^{\circ} \mathrm{F}$ gas temperature) \\
\hline
\end{tabular}

\subsection{References}

1. Chalfant, G. G., Safety Analysis Report - Packages USA/9965/B(U)F (DOE-SR) USA/9966/B(U)F (DOE-SR) USA/9967/B(U)F (DOE-SR) USA/9968/B(U)F (DOE-SR) (Packaging of Fissile and Other Radioactive Materials), DPSPU 83-124-1, June 1984.

2. Gromada, R. J., and Hensel, S. J., "Thermal Considerations For Overpack Designs In Drum Packages”, WSRC-MS-97-0193. 
WSRC-TR-98-00279

Engineered Equipment and Systems Department

APPENDIX 3

Dose Calculation for Pu-238 Oxide Payload in 9968 Shipping Container 
WSRC-TR-98-00279

Engineered Equipment and Systems Department

\section{Calculation Cover Sheet}

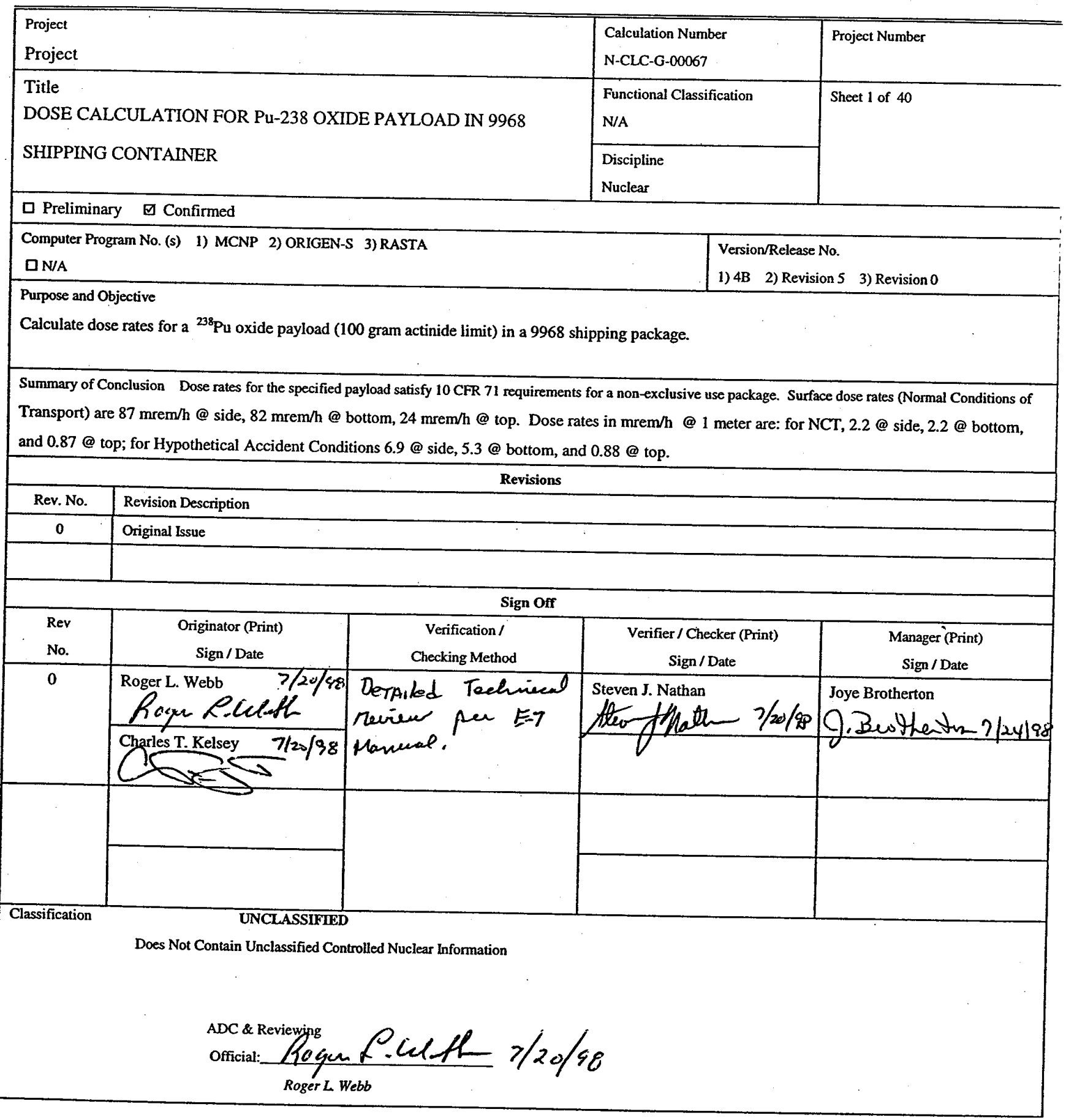




\section{TABLE OF CONTENTS}

INTRODUCTION
SUMMARY OF RESULTS
REGULATORY REQUIREMENTS
GEOMETRY
MATERIALS
SOURCE GENERATION
RESULTS - COMPUTED DOSE RATES
Hypothetical Accident Conditions - Neutron Sources
Hypothetical Accident Conditions - Photon Sources
Hypothetical Accident Conditions - SUMMARY
Normal Conditions of Transport - Neutron Sources
Normal Conditions of Transport - Photon Sources
Normal Conditions of Transport - SUMMARY
CONCLUSIONS
REFERENCES
APPENDIX A. Sample Input Decks.
A.1. ORIGEN-S Input Deck
A.2. RASTA Input Deck
A.3. MCNP Input (HAC, Gamma Source Groups 16 - 18, Bottom Dose) Deck
A.4. MCNP Input (HAC, Gamma Source Groups 8 - 15, Side Dose) Deck
A.5. MCNP Input (NCT, Neutron Source Groups 7 - 25, Top Doses) Deck
APPENDIX B. MCNP Information
B.1. MCNP Input and Output file Identification 18
B.2. Renormalization of MCNP Results

\section{LIST OF TABLES}

TABLE 1. 9968 Payload Envelope for ${ }^{238}$ Pu-Oxide Payload

TABLE 2. Radiation Dose Rates for the 9968 Shipping Container ..............................

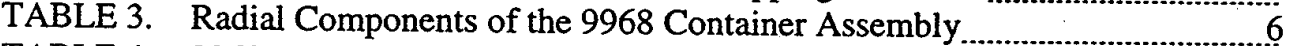

TABLE 4. 9968 Component Materials ...............................

TABLE 5. Elemental Composition (in weight fractions) of Steels

TABLE 6. Payload Isotopics Assumed for Transport Calculations ...............................?

TABLE 7. Payload Isotopic Activity (from ORIGEN-S)

TABLE 8. Neutron and Photon Source Distributions

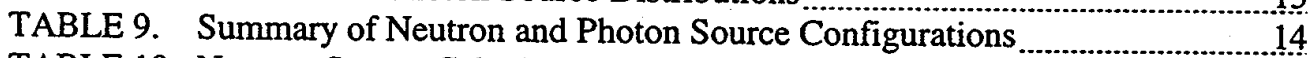

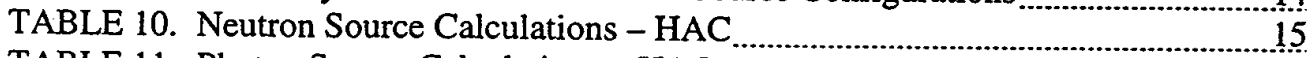

TABLE 11. Photon Source Calculations - HAC

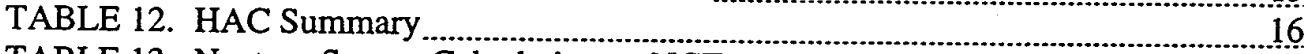

TABLE 13. Neutron Source Calculations - NCT

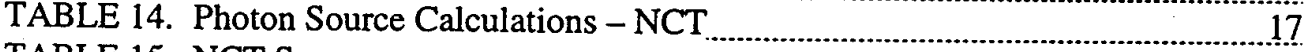

TABLE 15. NCT Summary

TABLE B.1. MCNP File Names

TABLE B.2. MCNP Tally Results and Normalization Constants 
WSRC-TR-98-00279

Engineered Equipment and Systems Department

Dose Calculation for Pu-238 Oxide Payload

in 9968 Shipping Container

N-CLC-G-00067

WSMSC-98-0207

Revision 0

\section{LIST OF FIGURES}

Figure 1. Schematic of 9968 Shipping Package $\ldots \ldots \ldots \ldots \ldots \ldots . .19$

Figure 2. Detail of PCV and SCV Closures

Figure 3. PCV/SCV Closure Geometry (Dimensions in $\mathrm{cm}$ ) $\ldots \ldots \ldots \ldots . . . . . .21$

Figure 4. Geometry for Gamma Source Calculations, Dose

Locations on Side

Figure 5. Geometry Used for Hypothetical Accident Conditions

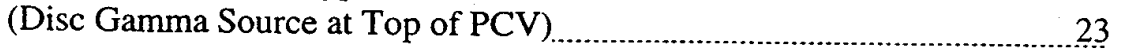




\section{INTRODUCTION}

The purpose of this work is to demonstrate that the 9968 shipping container meets Federal regulations for maximum radiation dose rates when loaded with the intended plutonium oxide payload. The dose calculations analyzed a ${ }^{238} \mathrm{Pu}$-oxide payload in a 9968 shipping container. The plutonium mass limit for the payload is 100 grams. The envelope for the payload contents is shown in Table 1. The particle transport calculations were performed using MCNP 4B (Ref. 1) on the WSMS workstation cluster. Flux-todose conversion factors from ANSU/ANS-6.1.1-1977 (Ref. 2) were used to convert computed fluxes to doses. The source term characterization was performed using ORIGIN-S (Ref. 3) and RASTA (Ref. 4).

\section{TABLE 1. 9968 Payload Envelope for ${ }^{238}$ Pu-Oxide Payload}

\begin{tabular}{|l|c|}
\hline \multicolumn{1}{|c|}{ ISOTOPES $^{2}$} & Weight Percent \\
\hline${ }^{241} \mathrm{Am}$ & 1.00000 \\
${ }^{243} \mathrm{Am}$ & 0.00010 \\
${ }^{244} \mathrm{Cm}$ & 0.00010 \\
${ }^{237} \mathrm{~Np}$ & 0.50000 \\
${ }^{236} \mathrm{Pu}$ & 0.00010 \\
${ }^{238} \mathrm{Pu}$ & 100.00000 \\
${ }^{239} \mathrm{Pu}$ & 40.00000 \\
${ }^{240} \mathrm{Pu}$ & 13.00000 \\
${ }^{241} \mathrm{Pu}$ & 1.00000 \\
${ }^{242} \mathrm{Pu}$ & 1.50000 \\
${ }^{232} \mathrm{Th}$ & 10.00000 \\
$\mathrm{U}$ & 1.00000 \\
Inert material & 100.00000 \\
\hline \hline Mass Limit & 100 grams \\
\hline
\end{tabular}

2 In addition to the isotopes listed in the table, small concentrations of other actinides, fission products, decay products, and neutron activation products are also permitted.

\section{SUMMARY OF RESULTS}

Table 2 summarizes results of the dose calculations. The computed doses are all well below the guidelines for non-exclusive use shipments as specified and defined in 10 CFR 71 .

Details of the calculations are presented later in this report.

This work has been done for an off-site shipper, so the neutron doses reported in Table 2 (and elsewhere throughout this report) are the "as-calculated" values and have not been multiplied by a factor of two as required by SRS' $5 \mathrm{Q}$ Manual. 
WSRC-TR-98-00279

Engineered Equipment and Systems Department

Dose Calculation for Pu-238 Oxide Payload

in 9968 Shipping Container

N-CLC-G-00067

WSMSC-98-0207

Revision 0

TABLE 2. Radiation Dose Rates for the 9968 Shipping Container

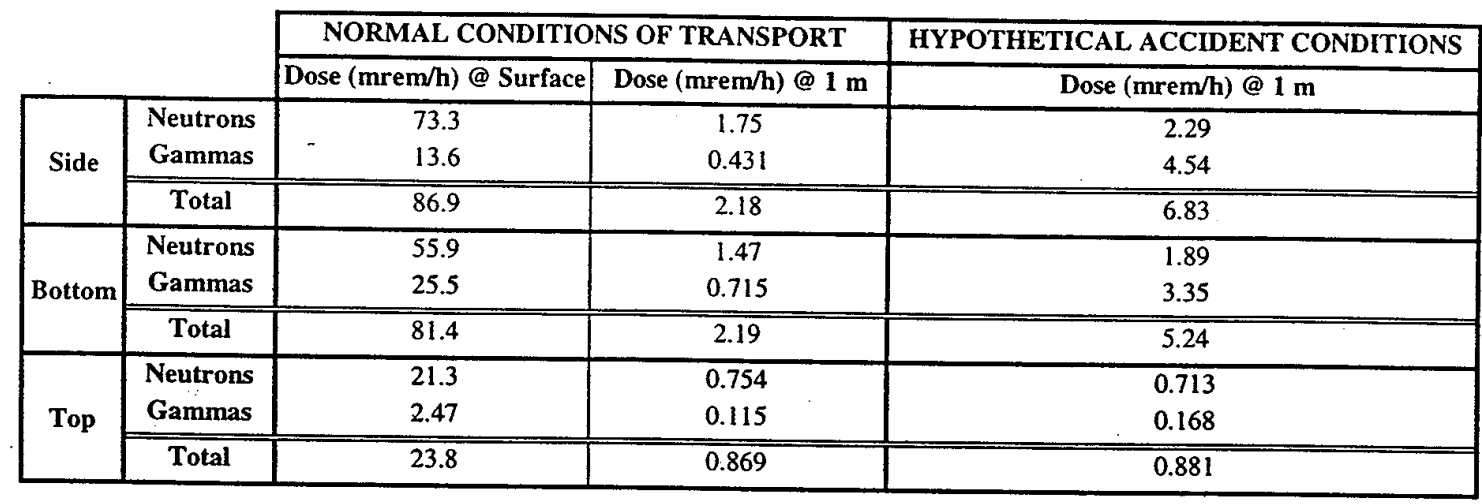

\section{REGULATORY REQUIREMENTS}

The Federal regulatory requirements applicable to the shielding requirements are given in 10 CFR 71.47 and 10 CFR 71.51. 10 CFR 71.4 also defines two terms: Exclusive Use and Transport Index. Exclusive use is defined as the sole use of a conveyance by a single consignor and for which all initial, intermediate, and final loading and unloading are carried out in accordance with the direction of the consignor or consignee. Packages must meet more stringent requirements to qualify as a non-exclusive use package. The 9968 cask, with the payload of Table 1, satisfies the shielding requirements for a nonexclusive use package. The transport index is a dimensionless number (rounded up to the next tenth) placed on the label of a package, to designate the degree of control to be exercised by the carrier during transportation. It is determined as either the maximum radiation level in $\mathrm{mrem} / \mathrm{hr}$ at 1 meter, or by the criticality control provisions of $\$ 71.59$.

10 CFR 71.47 states that for non-exclusive use the radiation dose rate at the surface of a package cannot exceed $200 \mathrm{mrem} / \mathrm{hr}$ at any point on the surface of the package. Furthermore, the transport index must not exceed 10. (Hence, the radiation level at 1 meter from the package cannot exceed $10 \mathrm{mrem} / \mathrm{hr}$.) In addition, $10 \mathrm{CFR} 71.51$ requires the radiation dose rate to not exceed $1000 \mathrm{mrem} / \mathrm{hr}$ at a distance of one meter from the external surface of the package under hypothetical accident conditions.

\section{GEOMETRY}

Details of the 9968 shipping container were taken from drawings S5-2-13101 (9968 Shipping Package Assembly), S5-2-13100 (9968 Stretched Double Containment Assembly), S5-2-13097 (9968 Stretched Primary Containment Vessel), S5-2-13098 (9968 Stretched Secondary Containment Vessel), and S4-2-767 (35 Gallon FullRemovable Head Drum).

A schematic of the package is shown in Figure 1. The 9968 consists of double stainless steel containment vessels, a lead shield, and 3 gane fiberboard (Celotex ${ }^{\mathrm{TM}}$ ) insulation 
WSRC-TR-98-00279

Engineered Equipment and Systems Department

Dose Calculation for Pu-238 Oxide Payload

N-CLC-G-00067

WSMSC-98-0207

Revision 0

inside a 35-gallon steel drum. The 0.5 -inch thick lead sheath is open at top and bottom. There is a 0.5 -inch stainless steel anti-rotation plate at the bottom of the shield, and a 0.5 inch aluminum plate at the top. Content separation is provided by aluminum honeycomb spacers in the bottom of the primary and secondary contain vessels (PCV and SCV) and on top of the PCV. The fissile payload is shown in Figure 1 as a $1.277 \mathrm{~cm}$ radius sphere at the bottom of the PCV. Details of the PCV/SCV closures are shown in Figures 2 and 3. Additional dimensions for the package are shown in Table 3 . Though dimensional tolerances were expected to have a negligible impact on the calculated doses, minimum and maximum pipe dimensions (for the PCV and SCV) were taken from ASTM A 530/A $530 \mathrm{M}-91 \mathrm{a}$ and used instead of nominal pipe dimensions.

TABLE 3. Radial Components of the 9968 Container Assembly

\begin{tabular}{|c|c|c|c|}
\hline Region Description & IR (cm) & OR (cm) & Material \\
\hline Primary Containment & 6.57098 & 7.02564 & 304L SS \\
\hline Secondary Containment & 7.87019 & 8.37438 & 304L SS \\
\hline Shield Liner & 9.3846 & 9.5377 & Void \\
\hline Lead Shield & 9.5377 & 10.7823 & Lead \\
\hline Fiberboard Packing & 10.922 & 22.86 & Celotex \\
\hline Drum & 23.1775 & 23.2989 & 304L SS \\
\hline
\end{tabular}

Table 4 shows specifications for the various components.

TABLE 4. 9968 Component Materials

\begin{tabular}{|l|l|c|}
\hline Component & Material & Density \\
\hline PCV & 304L - SS & 7.895 \\
SCV & $304 \mathrm{~L}$ - SS & 7.895 \\
Drum & $304 \mathrm{~L}$ - SS & 7.895 \\
Cone Seal Nut & Nitronic-60 SST & 7.895 \\
Cone Seal Plug & $304 \mathrm{~L}$ - SS & 7.895 \\
Vent Plug & $316-$ SS & 7.895 \\
Gland Nut & $410-$ SS & 7.895 \\
Aluminum Honeycomb & Aluminum & 0.28 \\
Aluminum Plate & Aluminum & 2.7 \\
Celotex & Cellulose & 0.20 \\
Shield & Lead & 11.29 \\
Shield Liner & Void & 0.0 \\
\hline
\end{tabular}


Simplifications made to the package geometry include:

- uniform PCV and SCV wall thickness (ignoring the flaring and, hence, the increased thickness at the vessel closures),

- simplified PCV and SCV vessel bottoms (PCV bottom approximated as a $10.97534 \mathrm{~cm}$ IR sphere; SCV by a $14.732 \mathrm{~cm}$ IR sphere),

- ignoring any product cans, plastic, or other inert materials that could be present inside the PCV,

- ignoring the 'legs' on the bottom of the PCV and SCV,

- modeling the gland nut's hexagonal outer surface as a cylinder having the equivalent cross-sectional area,

- modeling the Celotex as a single component, ignoring seams that exist between the different pieces of Celotex, and

- ignoring the rolling hoops and the drum lid closure.

Dimensions of the various components are given below. (The geometric model used in this analysis was adapted from that used for a 9975 analysis. The packages are very similar, with only minor differences. For example, the 9975 lead shield has a stainless steel liner that was changed to be void material for this analysis.)

- PCV - 6.57098 cm Inner Radius, $7.02564 \mathrm{~cm}$ Outer Radius, $41.5925 \mathrm{~cm}$ height from outer (bottom) surface of the PCV to the bottom of the primary cone seal plug; outer (bottom) surface is $17.4027 \mathrm{~cm}$ above the outer (bottom) surface of the 35 gallon drum.

- $\mathrm{SCV}-7.87019 \mathrm{~cm}$ Inner Radius, $8.37438 \mathrm{~cm}$ Outer Radius, $55.2323 \mathrm{~cm}$ height from outer (bottom) surface of the PCV to the bottom of the primary cone seal plug; outer (bottom) surface is $13.3929 \mathrm{~cm}$ above the outer (bottom) surface of the 35 gallon dium.

- Aluminum honeycomb above PCV $-4.572 \mathrm{~cm}$ high, $4.6725 \mathrm{~cm}$ Inner Radius, $7.46125 \mathrm{~cm}$ Outer Radius.

- Shield liner (void) - $9.3846 \mathrm{~cm}$ Inner Radius and $9.5377 \mathrm{~cm}$ Outer Radius.

- Lead shield - $9.5377 \mathrm{~cm}$ Inner Radius and $10.7823 \mathrm{~cm}$ Outer Radius; 62.3824 cm high (outer dimensions) - bottom is $12.2753 \mathrm{~cm}$ above the outer (bottom) surface of the 35 gallon drum.

- Stainless steel anti-rotation plate $-14.288 \mathrm{~cm}$ radius, $1.016 \mathrm{~cm}$ thick; bottom is $11.2593 \mathrm{~cm}$ above the outer (bottom) surface of the 35 gallon drum.

- Upper aluminum plate $-14.288 \mathrm{~cm}$ radius, $1.2446 \mathrm{~cm}$ thick; bottom rests on top of the lead shield and is $73.6417 \mathrm{~cm}$ above the outer (bottom) surface of the 35 gallon drum. 
WSRC-TR-98-00279

Engineered Equipment and Systems Department

Dose Calculation for Pu-238 Oxide Payload

in 9968 Shipping Container

N-CLC-G-00067

WSMSC-98-0207

Revision 0

- Celotex - $10.922 \mathrm{~cm}$ Inner Radius for bottom Celotex sections, $11.049 \mathrm{~cm}$ Inner Radius for top section; $22.86 \mathrm{~cm}$ Outer Radius for bottom Celotex sections, $22.479 \mathrm{~cm}$ Outer Radius for top section; the change in inner radii between top and bottom sections occurs at $62.1863 \mathrm{~cm}$ above the drum's outer (bottom) surface, and the change in outer radii occurs at $67.5203 \mathrm{~cm}$ above the drum's outer surface; top of Celotex at $85.0463 \mathrm{~cm}$ above the drum's outer (bottom) surface.

- Drum - $23.1775 \mathrm{~cm}$ Inner Radius and $23.2989 \mathrm{~cm}$ Outer Radius; $0.1087 \mathrm{~cm}$ bottom thickness; inner height $84.9376 \mathrm{~cm}$; external height $85.167712 \mathrm{~cm}$. (Differences between carbon steel and 304 stainless steel were ignored and the drum was assumed to be 304 stainless steel.)

Several different assumptions were made regarding the payload contents. Differing contents, as well as content locations, were used in order to maximize doses for the various dose locations. Specifically:

- for neutron and $(\mathrm{n}, \gamma)$ calculations, a $1.277151 \mathrm{~cm}$ sphere at $11.46 \mathrm{~g} / \mathrm{cm}^{3}$ was assumed with $59 \mathrm{wt}-\%{ }^{238} \mathrm{Pu}, 40 \mathrm{wt}-\%{ }^{239} \mathrm{Pu}$, and $1 \mathrm{wt}-\%{ }^{241} \mathrm{Pu}$. The contents and the spherical geometry were assumed in order to maximize the system's subcritical multiplication. The assumed density $\left(11.46 \mathrm{~g} / \mathrm{cm}^{3}\right)$ is the theoretical density of plutonium oxide - the oxygen content was ignored. For dose locations on the side or below the package, the fissile sphere was placed at the bottom of the PCV, touching the PCV side (see Figure 1). For dose locations above the package, the fissile sphere was placed at the top of the PCV, again touching the PCV side.

- for gamma source calculations, $52.020 \mathrm{wt}-\%{ }^{238} \mathrm{Pu}, 35.268 \mathrm{wt}-\%{ }^{239} \mathrm{Pu}, 0.882$ wt $\%{ }^{241} \mathrm{Pu}$, and $11.830 \mathrm{wt}-\%$ oxygen was assumed at $0.70 \mathrm{~g} / \mathrm{cm}^{3}\left(\mathrm{PuO}_{2}\right.$ bulk density). For dose locations on the side, a $20-\mathrm{cm}$ high, $0.734 \mathrm{~cm}$ thick, quarterannulus $(\mathbb{R}=5.83698 \mathrm{~cm}$ ) was assumed (see Figure 4). For dose locations above and below the package, a $1.0532-\mathrm{cm}$ thick disc source was assumed at the bottom or top (respectively) of the PCV.

For hypothetical accident conditions, all material outside of the SCV was ignored. Figure 5 is a schematic of the geometry used when computing the source gamma dose 1 meter above the package. Note that for that scenario, a disc gamma source at the top of the PCV was used.

\section{MATERIALS}

Composition of the various steels used in the calculations are given in Table 5. The lead shield was modeled as $100 \%$ lead at $11.29 \mathrm{~g} / \mathrm{cc}$. The aluminum honeycomb spacers and aluminum plate were modeled as $100 \%$ aluminum at 0.28 and $2.7 \mathrm{~g} / \mathrm{cm}^{3}$, respectively. The Celotex ${ }^{\mathrm{TM}}$ was modeled as cellulose, $\mathrm{C}_{6} \mathrm{H}_{10} \mathrm{O}_{5}$, at $0.20 \mathrm{~g} / \mathrm{cm}^{3}$ (Ref. 6). (The cane fiberboard $\left(\right.$ Celotex $\left.{ }^{\mathrm{TM}}\right)$ insulation has a nominal density of $16 \pm 2 \mathrm{lb} / \mathrm{ft}^{3}$, resulting in a 
WSRC-TR-98-00279

Engineered Equipment and Systems Department

Dose Calculation for Pu-238 Oxide Payload

N-CLC-G-00067

in 9968 Shipping Container

WSMSC-98-0207

Revision 0

minimum density of $0.224 \mathrm{~g} / \mathrm{cm}^{3}$. For conservatism, $0.20 \mathrm{~g} / \mathrm{cm}^{3}$ was used.) Payload isotopics assumed for the transport calculations are shown in Table 6.

TABLE 5. Elemental Composition (in weight fractions) of Steels ${ }^{5}$

\begin{tabular}{|l|c|cc|c|}
\cline { 2 - 5 } \multicolumn{1}{c|}{} & 316-SS & 304L-SS & 410-SS & Nitronic-60 \\
\hline Iron & 0.6917 & 0.7117 & 0.8603 & 0.655 \\
\hline Nickel & 0.1 & 0.08 & 0.005 & 0.08 \\
\hline Molybdenum & 0.02 & 0 & 0 & 0 \\
\hline Chromium & 0.16 & 0.18 & 0.115 & 0.16 \\
\hline Silicon & 0.0075 & 0.0075 & 0.0075 & 0.035 \\
\hline Carbon & 0.0008 & 0.0008 & 0.0015 & 0.001 \\
\hline Manganese & 0.02 & 0.02 & 0.01 & 0.07 \\
\hline Phosphorus & 0 & 0 & 0.0004 & 0 \\
\hline Sulfur & 0 & 0 & 0.0003 & 0 \\
\hline
\end{tabular}

TABLE 6. Payload Isotopics Assumed for Transport Calculations

\begin{tabular}{|c|c|c|}
\cline { 2 - 3 } \multicolumn{1}{c|}{} & \multicolumn{2}{c|}{ Material Composition -- Weight \% } \\
\cline { 2 - 3 } \multicolumn{1}{c|}{} & $\begin{array}{c}\text { Neutron and (n, } \gamma) \\
\text { Calculations }\end{array}$ & $\begin{array}{c}\text { Gamma Source } \\
\text { Calculations }\end{array}$ \\
\hline${ }^{238} \mathrm{Pu}$ & 59 & 52.020 \\
${ }^{239} \mathrm{Pu}$ & 40 & 35.268 \\
${ }^{241} \mathrm{Pu}$ & 1 & 0.882 \\
$\mathrm{O}$ & 0 & 11.830 \\
\hline \hline density $\left(\mathrm{g} / \mathrm{cm}^{3}\right)$ & 11.46 & 0.70 \\
\hline
\end{tabular}

\section{SOURCE GENERATION}

The source specifications for the Table 1 contents were assessed using the ORIGEN-S ${ }^{3}$ and RASTA ${ }^{4}$ codes. The approach taken in this evaluation uses ORIGEN-S to perform decay transmutations over 100 years beginning with the Table 1 content description. The source distributions as a function of time are generated for the BUGLE-80 group structure. The maximum source strengths reported for each group during 100 years of decay are used to conservatively establish the ORIGEN-S source distribution. The maximum isotopic activities reported by ORIGEN-S during 100 years of decay are then supplied as input to calculate the source distribution with RASTA. The final source distributions, one for photons and one for neutrons, include the larger of each group source strength as calculated with ORIGEN-S and RASTA. 
WSRC-TR-98-00279

Engineered Equipment and Systems Department

Dose Calculation for Pu-238 Oxide Payload

N-CLC-G-00067

in 9968 Shipping Container

WSMSC-98-0207

Revision 0

The isotopic composition of Table 1 is a list of allowable weight percentages that totals to 168 percent (ignoring, of course, inert materials since they do not contribute to the source term). In order to generate bounding source distributions, calculations of source strengths use a basis of 1.68 grams. The calculation assumed isotopic masses equivalent to the weight fractions of the Table 1 envelope.

The form of the actinides in the certified contents is oxide. For the source term calculations, two oxygen atoms are assumed present for each actinide atom. The total oxygen mass is calculated as the sum of the quotients of actinide masses and mass numbers multiplied by 32 , the oxide mass number. Naturally occurring oxygen isotopic abundances from the fifteen edition of the Chart of the Nuclides are used to calculate masses of each oxygen isotope. These are listed below.

\begin{tabular}{|c|c|c|c|}
\hline Element & $\begin{array}{c}\text { Mass } \\
\text { Number }\end{array}$ & $\begin{array}{c}\text { Natura1ly } \\
\text { Occuring } \\
\text { Percentages }\end{array}$ & $\begin{array}{c}\text { Oxygen } \\
\text { Masses } \\
\text { (grams) }\end{array}$ \\
\hline 0 & 16 & 99.76 & $2.25 \mathrm{E}-01$ \\
\hline 0 & 17 & 0.04 & $9.03 \mathrm{E}-05$ \\
\hline 0 & 18 & 0.20 & $4.52 \mathrm{E}-04$ \\
\hline Totals & - & $1.0 \mathrm{E}+02$ & $2.26 \mathrm{E}-01$ \\
\hline
\end{tabular}

The composition described was used to prepare an ORIGEN-S input deck with the ORIGINATE interface. The deck is given in Appendix A.1. Isotopic activities and energy group source magnitudes were both investigated as a function of decay time up to 100 years. The activities are listed in Table 7. The maximum activities and the decay time required to reach the maximum are also indicated. The maximum activities were used to prepare the RASTA input deck which is also given in Appendix A. Note that Bi212 and Po-216 have decay alphas at energies higher than those allowed in RASTA execution.

The source spectra calculated using both RASTA and ORIGEN-S are plotted below, first for neutrons and then for photons. The group source magnitudes are plotted versus the mean group energies. The ORIGEN-S spectra uses the peak magnitude of each individual group over the decay time studied. For photons, all maxima occur at 50 years or less. All neutron group maxima occur initially. The RATSA spectra is that generated using the peak isotopic activities tabulated above. The plots include the combined distribution which is obtained by conservatively taking the larger of the two values, the one from ORIGEN-S and the one from RASTA, for each group. Following the plots is Table 8, listing the combined source distributions.

The source specifications of Table 8 conservatively describe radiations that could be emitted from contents of a 9968 package bounded by the envelope of Table 1 . The basis for the magnitudes calculated is 1.68 grams of envelope actinide. This represents 168 percent of unit mass limit, implying that for envelope dose calculations the source strengths should be interpreted as particles per second per gram of contained actinlde. 
WSRC-TR-98-00279

Engineered Equipment and Systems Department

Dose Calculation for Pu-238 Oxide Payload

N-CLC-G-00067

in 9968 Shipping Container

WSMSC-98-0207

Revision 0

TABLE 7. Payload Isotopic Activity (from ORIGEN-S)

\begin{tabular}{|c|c|c|c|c|c|c|c|c|c|c|c|}
\hline \multirow[b]{2}{*}{ Isorope } & \multicolumn{9}{|c|}{ Activities (Curies pez basis) at Decay Time } & \multirow{2}{*}{$\begin{array}{l}\text { Maximum } \\
\text { Activity }\end{array}$} & \multirow{2}{*}{$\begin{array}{c}\text { Maximum } \\
\text { Time }\end{array}$} \\
\hline & initial & $0.3 y=$ & $1.0 \mathrm{yr}$ & $3.0 \mathrm{yr}$ & $10.0 \mathrm{yx}$ & $25.0 \mathrm{yr}$ & $50.0 \mathrm{yt}$ & $75.0 \mathrm{yr}$ & $100.0 \mathrm{Yz}$ & & \\
\hline 51208 & $0.00 E+00$ & $2.86 \mathrm{E}-0 \mathrm{~B}$ & $2.77 \varepsilon-07$ & $1.698-05$ & $5.91 E-06$ & $5.47 \mathrm{E}-06$ & $5.10 \mathrm{E}-06$ & $3.98 \mathrm{E}-05$ & $3.11 \mathrm{E}-06$ & $6.47 \mathrm{E}-06$ & $25.9 \gamma^{r}$ \\
\hline $\mathrm{pb} 212$ & $0.00 \varepsilon+00$ & $7.96 E-08$ & $7.69 \varepsilon-07$ & $4.71 \mathrm{E}-06$ & $1.52 \mathrm{E}-0.5$ & $1.80 \varepsilon-05$ & $1.42 \mathrm{E}-05$ & $1.11 \mathrm{E}-05$ & $3.64 \mathrm{E}-06$ & $1.30 \mathrm{E}-05$ & $25.3 \mathrm{Yr}$ \\
\hline bi212 & $0.00 \varepsilon+00$ & $7.96 \mathrm{E}-0 \mathrm{~B}$ & $7.69 E-07$ & $4.71 \mathrm{E}-05$ & $1.52 \mathrm{E}-05$ & $1.80 E-05$ & $1.42 \mathrm{E}-05$ & $1.11 \mathrm{E}-05$ & $8.64 \mathrm{E}-06$ & $1.30 \mathrm{E}-25$ & $25.0 \mathrm{Yr}$ \\
\hline & $0.00 \mathrm{E}+00$ & $5.10 \mathrm{E}-0 \mathrm{~B}$ & $4.93 \mathrm{E}-07$ & $3.02 \mathrm{E}-06$ & $1.03 \mathrm{E}-05$ & $1.15 \mathrm{E}-05$ & $9.09 \mathrm{E}-06$ & $7.09 \mathrm{E}-06$ & $5.53 \mathrm{E}-06$ & $1.15 \mathrm{E}-05$ & $25.0 \mathrm{Yr}$ \\
\hline po216 & $0.00 \varepsilon+00$ & $7.96 \varepsilon-08$ & $7.69 \mathrm{E}-07$ & $4.71 \mathrm{E}-05$ & $1.62 \mathrm{E}-05$ & $1.80 \mathrm{E}-05$ & $1.42 \varepsilon-05$ & $1.11 \mathrm{E}-05$ & $8.64 E-06$ & $1.90 \mathrm{E}-05$ & $25.0 \mathrm{yz}$ \\
\hline $\operatorname{sn} 220$ & $0.00 \varepsilon+00$ & $7.96 \mathrm{E}-08$ & $7.69 \mathrm{E}-07$ & $4.71 \mathrm{E}-05$ & $1.52 \mathrm{E}-05$ & $1.80 \mathrm{E}-0 \mathrm{~S}$ & $1.42 \mathrm{E}-05$ & $2.11 \mathrm{E}-05$ & B.64E-05 & $1.30 \mathrm{E}-05$ & $25.2 y x$ \\
\hline $5 a 224$ & $0.00 \mathrm{E}+00$ & $7.96 \mathrm{E}-08$ & $7.69 E-07$ & $4.71 \mathrm{E}-06$ & $1.52 \mathrm{E}-0.5$ & $1.30 \mathrm{E}-05$ & $1.42 \mathrm{E}-05$ & $1.11 \mathrm{E}-05$ & $3.54 \mathrm{E}-06$ & $1.90 E-05$ & $25.2 \mathrm{Yr}$ \\
\hline $\mathrm{ra223}$ & $0.00 E+00$ & $3.90 \mathrm{E}-10$ & $1.25 \mathrm{E}-09$ & $3.33 \mathrm{E}-09$ & $7.39 \mathrm{E}-09$ & $1.04 E-98$ & $1.09 \varepsilon-08$ & $1.10 \mathrm{E}-08$ & $1.10 \mathrm{E}-08$ & $1.10 \mathrm{E}-08$ & $75.0 \mathrm{Vt}$ \\
\hline $\mathrm{ac} 229$ & $0.00 E+00$ & $3.90 \mathrm{E}-10$ & $1.25 \mathrm{E}-09$ & $3.33 \mathrm{E}-09$ & $7.69 \mathrm{E}-09$ & $1.04 E-08$ & $1.09 \mathrm{E}-08$ & $1.10 \mathrm{E}-98$ & $1.10 \mathrm{E}-08$ & $1.10 \mathrm{E}-08$ & $75.0 y^{2}$ \\
\hline $\operatorname{th} 22 \mathrm{~g}$ & $0.00 \mathrm{E}+00$ & $7.96 \mathrm{E}-08$ & $7.69 E-07$ & $4.71 \mathrm{E}-06$ & $1.52 \mathrm{E}-05$ & $1.80 \mathrm{E}-0 \mathrm{~S}$ & $1.42 \mathrm{E}-05$ & $1.11 \mathrm{E}-05$ & $8.64 E-06$ & $1.80 \mathrm{E}-05$ & $25.0 \mathrm{yr}$ \\
\hline $\operatorname{th} 230$ & $0.00 E+00$ & $2.00 \mathrm{E}-11$ & $2.22 \mathrm{E}-10$ & $1.90 \mathrm{E}-09$ & $2.15 E-08$ & $1.30 \mathrm{E}-07$ & $4.89 \mathrm{E}-07$ & $1.04 E-06$ & $1.74 \mathrm{E}-06$ & $1.74 E-06$ & $100.0 \mathrm{yt}$ \\
\hline $\operatorname{ch} 231$ & $0.00 \mathrm{E}+00$ & $3.08 \mathrm{E}-08$ & $1.08 \mathrm{E}-08$ & $1.09 \mathrm{E}-0 \mathrm{~B}$ & $1.11 \mathrm{E}-08$ & $1.14 \mathrm{E}-0 \mathrm{~g}$ & $1.20 \mathrm{E}-0 \mathrm{~B}$ & $1.26 \mathrm{E}-08$ & $1.33 \mathrm{E}-08$ & $1.33 \mathrm{E}-08$ & $100.0 \mathrm{yx}$ \\
\hline $\operatorname{th} 232$ & $1.10 \mathrm{E}-08$ & $1.10 \mathrm{E}-0 \mathrm{8}$ & $1.10 \mathrm{E}-08$ & $1.10 \mathrm{E}-08$ & $1,10 \mathrm{E}-0 \mathrm{~B}$ & $1.10 \mathrm{E}-08$ & $1.10 \mathrm{E}-\mathrm{OB}$ & $1.10 \mathrm{E}-08$ & $1.10 \mathrm{E}-08$ & $1.13 \mathrm{E}-0 \mathrm{~B}$ & inicial \\
\hline $\operatorname{ch} 234$ & $0.00 \mathrm{E}+00$ & $1.61 \mathrm{E}-09$ & $1.68 \mathrm{E}-09$ & $1.68 \mathrm{E}-09$ & $1.58 \mathrm{E}-09$ & $1.68 \mathrm{E}-09$ & $1.68 \mathrm{E}-09$ & $1.68 \mathrm{E}-09$ & $1.68 \mathrm{E}-09$ & $1.68 \mathrm{E}-09$ & $1.0 \mathrm{yr}$ \\
\hline pa233 & $0.00 \mathrm{E}+00$ & $3.32 \mathrm{E}-06$ & $3.54 E-06$ & $3.56 \mathrm{E}-06$ & $3.66 \mathrm{E}-06$ & $3.91 \mathrm{E}-06$ & $4.40 z-06$ & $4.89 \varepsilon-06$ & $5.38 \mathrm{E}-05$ & $5.38 \mathrm{E}-06$ & $100.0 \mathrm{yx}$ \\
\hline pa234in & $0.00 \mathrm{E}+00$ & $1.61 \mathrm{E}-09$ & $1.68 \mathrm{E}-09$ & & $1.58 \mathrm{E}-09$ & $1.68 \mathrm{E}-09$ & $1.68 \mathrm{E}-09$ & $1.68 \mathrm{E}-09$ & $1.68 \mathrm{E}-09$ & $1.68 \mathrm{E}-09$ & $1.0 \mathrm{yr}$ \\
\hline pa234 & $0.00 \mathrm{E}+00$ & $2.09 \mathrm{E}-12$ & $2.19 \mathrm{E}-12$ & $2.19 \mathrm{E}-12$ & $2.19 E-12$ & $2.19 \varepsilon-12$ & $2.19 \mathrm{E}-12$ & $2.19 \mathrm{E}-12$ & $2.19 \mathrm{E}-12$ & $2.19 \mathrm{E}-12$ & $1.0 \mathrm{yr}$ \\
\hline 4232 & $0.00 \mathrm{E}+00$ & $1.50 \mathrm{E}-06$ & $4.59 \mathrm{E}-06$ & $1.09 E-05$ & $1.34 \mathrm{E}-05$ & $1.76 \mathrm{E}-05$ & $1.38 \mathrm{E}-05$ & $3.08 \mathrm{E}-05$ & $8.39 \mathrm{E}-06$ & $1.84 \mathrm{E}-05$ & $10.0 \mathrm{yr}$ \\
\hline 4233 & $0.00 E+00$ & $3.07 \mathrm{E}-12$ & $1.37 \mathrm{E}-11$ & $4.63 \mathrm{E}-11$ & $1.56 \mathrm{E}-10$ & $4.03 \mathrm{E}-10$ & $E-10$ & $E-09$ & $1.92 \mathrm{E}-09$ & $1.92 \mathrm{E}-09$ & $100.0 \mathrm{yx}$ \\
\hline 4234 & $0.00 \mathrm{E}+00$ & $1.45 \mathrm{E}-05$ & $4.81 \mathrm{E}-05$ & $1.43 \mathrm{E}-04$ & $4.65 \mathrm{E}-04$ & $1.10 \mathrm{E}-03$ & $2.00 \mathrm{E}-03$ & $2.73 \mathrm{E}-03$ & $3.34 \mathrm{E}-03$ & $3.34 \mathrm{E}-03$ & $100.0 \mathrm{yx}$ \\
\hline 4235 & $1.08 \mathrm{E}-08$ & $1.08 \mathrm{E}-08$ & $1.08 \mathrm{E}-08$ & $1.09 \mathrm{E}-0 \mathrm{~B}$ & I. $11 E-08$ & $1.14 \mathrm{E}-08$ & $1.20 \mathrm{E}-08$ & $1.26 \mathrm{E}-08$ & $1.33 \mathrm{E}-08$ & $1.33 \mathrm{E}-08$ & $100.0 \mathrm{yx}$ \\
\hline & $0.00 E+00$ & $2.62 \mathrm{E}-10$ & $8.74 E-10$ & $2.62 \mathrm{E}-09$ & $8.73 \mathrm{E}-09$ & -08 & -08 & $6.53 \mathrm{E}-08$ & $8.69 \mathrm{E}-08$ & $8.69 \mathrm{E}-08$ & $100.0 \mathrm{yr}$ \\
\hline 4237 & $0.00 \mathrm{E}+00$ & $2.44 E-05$ & $2.36 \mathrm{E}-05$ & $2.14 \varepsilon-05$ & $1.53 \mathrm{E}-05$ & $7.408-06$ & $2.21 \mathrm{E}-06$ & $6.61 \mathrm{E}-07$ & $1.97 \mathrm{E}-07$ & $2.44 \mathrm{E}-05$ & $0.3 \mathrm{yx}$ \\
\hline 4238 & $1.68 \mathrm{E}-09$ & $1.68 \mathrm{E}-09$ & $1.68 \mathrm{E}-09$ & $1.68 \mathrm{E}-09$ & $1.68 \mathrm{E}-09$ & $1.68 \mathrm{E}-09$ & $1.68 \mathrm{E}-09$ & $1.68 \mathrm{E}-09$ & $1.68 \mathrm{E}-09$ & $1.68 \mathrm{E}-09$ & initial \\
\hline np237 & $3,53 \mathrm{E}-06$ & $3.53 \mathrm{E}-06$ & $3.54 \mathrm{E}-06$ & $3.568-06$ & $3.66 \mathrm{E}-06$ & $3.91 \mathrm{E}-06$ & $4.40 \mathrm{E}-06$ & $4.89 \mathrm{E}-06$ & $5.38 \mathrm{E}-06$ & $5.38 \mathrm{E}-06$ & $100.0 \mathrm{yt}$ \\
\hline np239 & $0.00 \mathrm{E}+00$ & $2.00 \mathrm{E}-07$ & $2.00 \mathrm{E}-07$ & $2.00 \mathrm{E}-07$ & $1.99 \mathrm{E}-07$ & $1.99 \mathrm{E}-07$ & $1.99 \mathrm{E}-07$ & $1.98 \mathrm{E}-07$ & $1.98 \mathrm{E}-07$ & $2.00 \mathrm{E}-07$ & $0.3 \mathrm{yz}$ \\
\hline pu236 & $5.23 \mathrm{E}-04$ & $4.86 \mathrm{E}-04$ & $4.11 \mathrm{E}-04$ & $2.558-04$ & $4.79 E-05$ & $1.33 \mathrm{E}-06$ & $3.37 \mathrm{E}-09$ & $8.56 \mathrm{E}-12$ & $2.17 \mathrm{E}-14$ & $5.23 E-04$ & initial \\
\hline pu238 & $1.71 \mathrm{E}+01$ & $1.71 E+01$ & $1.70 \mathrm{E}+01$ & $1.67 \mathrm{E}+01$ & $1.58 \Sigma+01$ & $1.41 E+01$ & $1.15 \mathrm{E}+01$ & $9.47 \mathrm{E}+00$ & $7.77 \varepsilon+00$ & $1.71 \mathrm{E}+01$ & initial \\
\hline pu239 & $2.48 E-02$ & $2.48 \mathrm{E}-02$ & $2.49 \mathrm{~g}-02$ & $2.48 \mathrm{E}-02$ & $2.48 \mathrm{E}-02$ & $2.48 \mathrm{~B}-02$ & $2.48 \mathrm{E}-02$ & $2.48 \mathrm{E}-02$ & $2.48 \mathrm{E}-02$ & $2.48 E-02$ & initial \\
\hline pu240 & $2.95 \mathrm{E}-02$ & $2.95 \mathrm{E}-02$ & $2.95 \mathrm{E}-02$ & $2.95 \mathrm{E}-02$ & $2.95 \mathrm{E}-02$ & $2.94 \mathrm{E}-02$ & $2.94 \mathrm{E}-02$ & $2.93 \mathrm{E}-02$ & $2.92 \mathrm{E}-02$ & $2.95 \mathrm{E}-02$ & initial \\
\hline pu241 & $1.03 \mathrm{E}+00$ & $1.02 \mathrm{E}+00$ & $9.85 \mathrm{E}-01$ & $8.95 \mathrm{E}-01$ & $6.38 \mathrm{\varepsilon}-01$ & $3.09 \mathrm{E}-01$ & $9.24 \mathrm{E}-02$ & $2.76 \mathrm{E}-02$ & $8.25 E-03$ & $1.03 \mathrm{E}+00$ & inirial \\
\hline pu242 & $5.93 \mathrm{E}-05$ & $5.93 \mathrm{E}-05$ & $5.93 \mathrm{E}-05$ & $5.93 \mathrm{E}+05$ & $5.93 E-05$ & $5.93 \varepsilon-05$ & $5.93 \mathrm{E}-05$ & $5.93 \mathrm{E}-05$ & $5.93 \mathrm{E}-05$ & $5.93 \mathrm{E}-05$ & initial \\
\hline $\operatorname{an} 241$ & $3.43 \mathrm{E}-02$ & $3.48 \mathrm{E}-02$ & $3.59 \mathrm{~g}-02$ & $3.88 \varepsilon-02$ & $4.68 \mathrm{E}-02$ & $5.64 \mathrm{E}-02$ & $6.13 \mathrm{E}-02$ & $6.09 \mathrm{E}-02$ & $5.92 \mathrm{E}-02$ & $6.13 \varepsilon-02$ & $50.0 \mathrm{yx}$ \\
\hline $\operatorname{an} 243$ & $2.00 \mathrm{E}-07$ & $2.00 \mathrm{E}-07$ & $2.00 \mathrm{E}-07$ & $2.00 \varepsilon-07$ & $1.99 \varepsilon-07$ & $1.99 \mathrm{E}-07$ & $1.99 \mathrm{E}-07$ & $1.98 \mathrm{E}-07$ & $1.98 \mathrm{E}-07$ & 2.00E-07 & initial \\
\hline $\operatorname{cm} 244$ & $8.10 \mathrm{E}-05$ & $8.01 \mathrm{E}-05$ & $7.79 \mathrm{E}-05$ & $7.22 \mathrm{E}-05$ & $5.52 \mathrm{E}-05$ & $3.11 \mathrm{E}-05$ & $1.19 \mathrm{~g}-05$ & $4.58 \mathrm{E}-06$ & $1.76 \mathrm{E}-06$ & $8.10 \mathrm{E}-05$ & initial \\
\hline totals & $1.83 \mathrm{E}+01$ & $1.82 E+01$ & $1.81 \mathrm{E}+01$ & $1.77 \mathrm{E}+01$ & $1.66 \mathrm{E}+01$ & $1.45 \mathrm{E}+01$ & $1.17 \mathrm{E}+01$ & $9.62 \mathrm{E}+00$ & $7.90 \mathrm{E}+00$ & $1.82 \mathrm{E}+01$ & $\mathrm{NA}$ \\
\hline
\end{tabular}


WSRC-TR-98-00279

Engineered Equipment and Systems Department

Dose Calculation for Pu-238 Oxide Payload

in 9968 Shipping Container
N.CLC-G-00067

WSMSC-98-0207

Revision 0
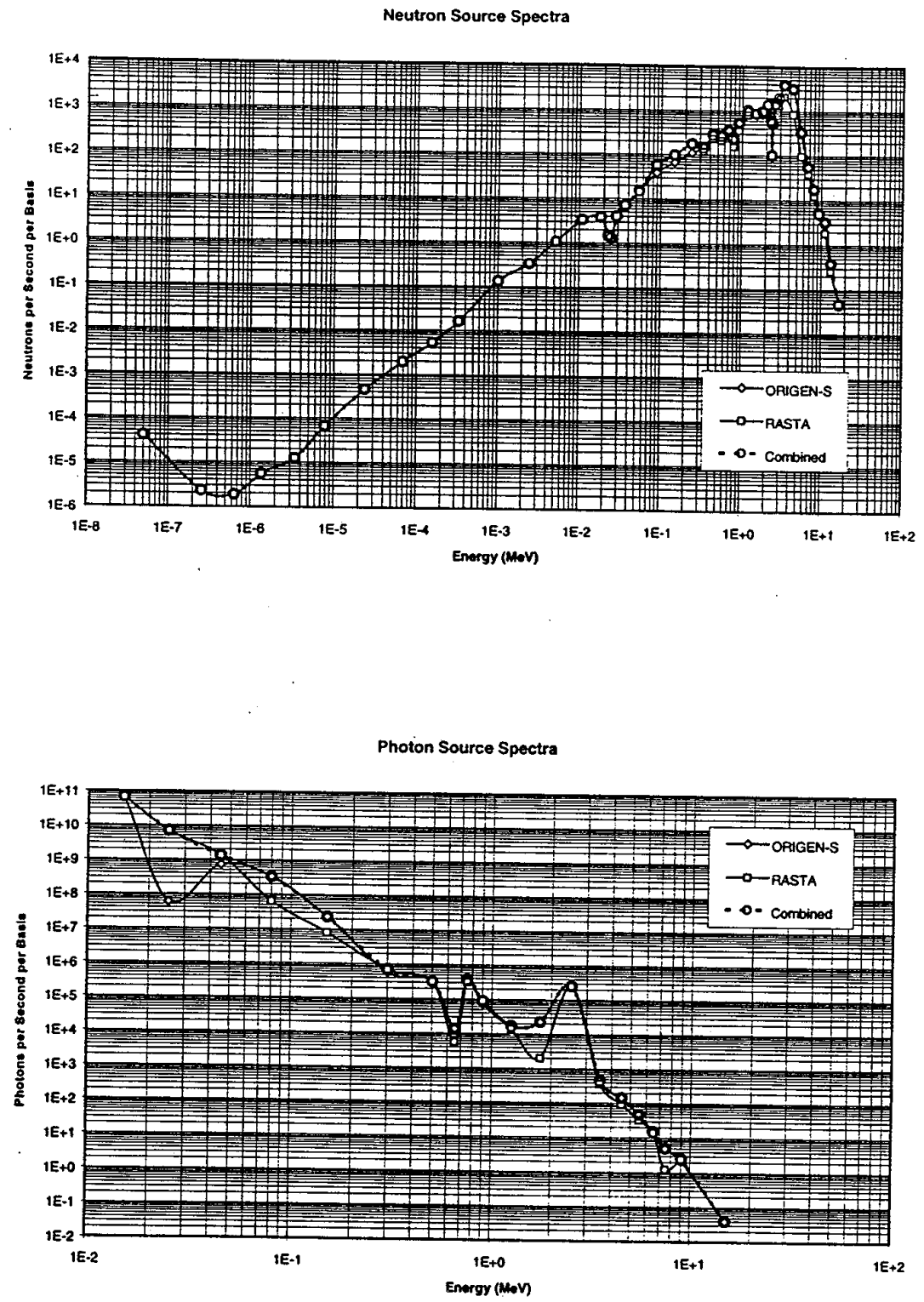
WSRC-TR-98-00279

Engineered Equipment and Systems Department

Dose Calculation for Pu-238 Oxide Payload

in 9968 Shipping Container

N-CLC-G-00067

WSMSC-98-0207

Revision 0

TABLE 8. Neutron and Photon Source Distributions

\begin{tabular}{|c|c|c|c|c|c|c|c|}
\hline $\begin{array}{c}\text { BUGLE } \\
\text { Neutron } \\
\text { Group } \\
\text { Number } \\
\end{array}$ & 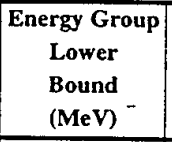 & $\begin{array}{c}\text { Energy Group } \\
\text { Upper } \\
\text { Bound } \\
\text { (MeV) } \\
\end{array}$ & $\begin{array}{c}\text { Neutron Source } \\
(n / s \text { per g actinide) }\end{array}$ & $\begin{array}{l}\text { BUGLE } \\
\text { Photon } \\
\text { Group } \\
\text { Number }\end{array}$ & \begin{tabular}{|c|} 
Energy Group \\
Lower \\
Bound \\
(MeV) \\
\end{tabular} & \begin{tabular}{|c|} 
Energy Group \\
Upper \\
Bound \\
(MeV) \\
\end{tabular} & $\begin{array}{l}\text { Photon Source } \\
\text { ( } \gamma / \text { s per g actinide) }\end{array}$ \\
\hline 47 & $1.0000 \mathrm{E}-11$ & $1.0000 \mathrm{E}-07$ & $3.97 \mathrm{E}-05$ & 20 & $1.00 \mathrm{E}-02$ & $2.00 \mathrm{E}-02$ & $6.67 \mathrm{E}+10$ \\
\hline 46 & $1.0000 \mathrm{E}-07$ & $4.1400 \mathrm{E}-07$ & $2.26 \mathrm{E}-06$ & 19 & $2.00 \mathrm{E}-02$ & $3.00 \mathrm{E}-02$ & $6.79 \mathrm{E}+09$ \\
\hline 45 & $4.1400 \mathrm{E}-07$ & $8.7642 \mathrm{E}-07$ & $1.87 \mathrm{E}-06$ & 18 & $3.00 \mathrm{E}-02$ & $6.00 \mathrm{E}-02$ & $1.32 \mathrm{E}+09$ \\
\hline 44 & $8.7642 \mathrm{E}-07$ & $1.8554 \mathrm{E}-06$ & $5.53 \mathrm{E}-06$ & 17 & $6.00 \mathrm{E}-02$ & $1.00 \mathrm{E}-01$ & $3.24 \mathrm{E}+08$ \\
\hline 43 & 1.8554E-06 & $5.0435 \mathrm{E}-06$ & $1.26 \mathrm{E}-05$ & 16 & $1.00 \mathrm{E}-01$ & $2.00 \mathrm{E}-01$ & $2.27 \bar{E}+07$ \\
\hline 42 & $5.0435 \mathrm{E}-06$ & $1.0667 \mathrm{E}-05$ & $6.76 \mathrm{E}-05$ & 15 & $2.00 \mathrm{E}-01$ & $4.00 \mathrm{E}-01$ & $6.96 \mathrm{E}+05$ \\
\hline 41 & $1.0667 \mathrm{E}-05$ & $3.7267 \mathrm{E}-05$ & $4.58 \mathrm{E}-04$ & 14 & $4.00 \mathrm{E}-01$ & $6.00 \mathrm{E}-01$ & $3.21 E+05$ \\
\hline 40 & $3.7267 \mathrm{E}-05$ & $1.0130 \mathrm{E}-04$ & $1.94 \mathrm{E}-03$ & 13 & $6.00 \mathrm{E}-0 \mathrm{I}$ & $7.00 \mathrm{E}-01$ & $1.36 \mathrm{E}+04$ \\
\hline 39 & $1.0130 \mathrm{E}-04$ & $2.1445 \mathrm{E}-04$ & $5.26 \mathrm{E}-03$ & 12 & $7.00 \mathrm{E}-01$ & $8.00 \mathrm{E}-01$ & $3.72 \mathrm{E}+05$ \\
\hline 38 & $2.1445 \mathrm{E}-04$ & $4.5400 \mathrm{E}-04$ & $1.61 \mathrm{E}-02$ & 11 & $8.00 \mathrm{E}-01$ & $1.00 \mathrm{E}+00$ & $8.76 \mathrm{E}+04$ \\
\hline 37 & $4.5400 \mathrm{E}-04$ & $1.5846 \mathrm{E}-03$ & $1.32 \mathrm{E}-01$ & 10 & $1.00 \mathrm{E}+00$ & $1.50 \mathrm{E}+00$ & $1.69 \mathrm{E}+04$ \\
\hline 36 & $1.5846 \mathrm{E}-03$ & $3.3546 \mathrm{E}-03$ & $3.32 \mathrm{E}-01$ & 9 & $1.50 \mathrm{E}+00$ & $2.00 \mathrm{E}+00$ & $2.24 E+04$ \\
\hline 35 & $3.3546 \mathrm{E}-03$ & $7.1017 \mathrm{E}-03$ & $1.05 \mathrm{E}+00$ & 8 & $2.00 \mathrm{E}+00$ & $3.00 \mathrm{E}+00$ & $2.52 \mathrm{E}+05$ \\
\hline 34 & $7.1017 \mathrm{E}-03$ & $1.5034 \mathrm{E}-02$ & $3.36 \mathrm{E}+00$ & 7 & $3.00 \mathrm{E}+00$ & $4.00 \mathrm{E}+00$ & $4.61 \mathrm{E}+02$ \\
\hline 33 & $1.5034 \mathrm{E}-02$ & $2.1875 \mathrm{E}-02$ & $3.92 \mathrm{E}+00$ & 6 & $4.00 \mathrm{E}+00$ & $5.00 \mathrm{E}+00$ & $1.46 \bar{E}+02$ \\
\hline 32 & $2.1875 \mathrm{E}-02$ & $2.4176 \mathrm{E}-02$ & $1.48 \mathrm{E}+00$ & 5 & $5.00 \mathrm{E}+00$ & $6.00 \mathrm{E}+00$ & $4.68 \mathrm{E}+01$ \\
\hline 31 & $2.4176 \mathrm{E}-02$ & $2.6058 \mathrm{E}-02$ & $1.28 \mathrm{E}+00$ & 4 & $6.00 \mathrm{E}+00$ & $7.00 \mathrm{E}+00$ & $1.52 \mathrm{E}+01$ \\
\hline 30 & $2.6058 \mathrm{E}-02$ & $3.1828 \mathrm{E}-02$ & $4.08 \mathrm{E}+00$ & 3 & $7.00 \mathrm{E}+00$ & $8.00 \mathrm{E}+00$ & $4.96 \mathrm{E}+00$ \\
\hline 29 & $3.1828 \mathrm{E}-02$ & $4.0868 \mathrm{E}-02$ & $7.21 \mathrm{E}+00$ & 2 & $8.00 \mathrm{E}+00$ & $1.00 \mathrm{E}+01$ & $2.46 \mathrm{E}+00$ \\
\hline 28 & $4.0868 \mathrm{E}-02$ & $6.7379 \mathrm{E}-02$ & $1.55 \mathrm{E}+0 \mathrm{l}$ & 1 & $1.00 \mathrm{E}+01$ & $2.00 \mathrm{E}+01$ & $3.90 \mathrm{E}-02$ \\
\hline 27 & $6.7379 \mathrm{E}-02$ & $1.1109 \mathrm{E}-01$ & $5.80 \mathrm{E}+01$ & & & & \\
\hline 26 & $1.1109 \mathrm{E}-01$ & $1.8316 \mathrm{E}-01$ & $9.99 \mathrm{E}+01$ & & & & \\
\hline 25 & $1.8316 \mathrm{E}-01$ & $2.9720 \mathrm{E}-01$ & $1.78 \mathrm{E}+02$ & & & & \\
\hline 24 & $2.9720 \mathrm{E}-01$ & $3.6883 \mathrm{E}-01$ & $1.51 \mathrm{E}+02$ & & & & \\
\hline 23 & $3.6883 \mathrm{E}-01$ & $4.9787 \mathrm{E}-01$ & $2.97 \mathrm{E}+02$ & & & & \\
\hline 22 & $4.9787 \mathrm{E}-01$ & $6.0810 \mathrm{E}-01$ & $2.79 E+02$ & & & & \\
\hline 21 & $6.0810 \mathrm{E}-01$ & $7.4274 \mathrm{E}-01$ & $3.65 \mathrm{E}+02$ & & & & \\
\hline 20 & $7.4274 \mathrm{E}-01$ & $8.2085 \mathrm{E}-01$ & $2.32 \mathrm{E}+02$ & & & & \\
\hline 19 & $8.2085 \mathrm{E}-0 \mathrm{I}$ & $1.0026 \mathrm{E}+00$ & $5.37 \mathrm{E}+02$ & & & & \\
\hline 18 & $1.0026 \mathrm{E}+00$ & $1.3534 \mathrm{E}+00$ & $1.04 \mathrm{E}+03$ & & & & \\
\hline 17 & $1.3534 \mathrm{E}+00$ & $1.6530 \mathrm{E}+00$ & $8.77 \mathrm{E}+02$ & & & & \\
\hline 16 & $1.6530 \mathrm{E}+00$ & $1.9205 \mathrm{E}+00$ & $9.88 \mathrm{E}+02$ & & & & \\
\hline 15 & $1.9205 \mathrm{E}+00$ & $2.2313 \mathrm{E}+00$ & $1.40 E+03$ & & & & \\
\hline 14 & $2.2313 \mathrm{E}+00$ & $2.3457 \mathrm{E}+\infty 0$ & $6.06 \mathrm{E}+02$ & & & & \\
\hline 13 & $2.3457 E+00$ & $2.3653 \mathrm{E}+00$ & $1.03 \mathrm{E}+02$ & & & & \\
\hline 12 & $2.3653 \mathrm{E}+00$ & $2.4660 \mathrm{E}+00$ & $5.21 \mathrm{E}+02$ & & & & \\
\hline II & $2.4660 \mathrm{E}+00$ & $2.7253 \mathrm{E}+\infty 0$ & $1.53 \mathrm{E}+03$ & & & & \\
\hline 10 & $2.7253 \mathrm{E}+00$ & $3.0119 \mathrm{E}+00$ & $1.94 \mathrm{E}+03$ & & & & \\
\hline 9 & $3.0119 \mathrm{E}+00$ & $3.6788 \mathrm{E}+00$ & $3.86 \mathrm{E}+03$ & & & & \\
\hline 8 & $3.6788 \mathrm{E}+00$ & $4.9659 \mathrm{E}+00$ & $3.18 \mathrm{E}+03$ & & & & \\
\hline 7 & $4.9659 \mathrm{E}+00$ & $6.0653 \mathrm{E}+00$ & $3.43 E+02$ & & & & \\
\hline 6 & $6.0653 E+\infty$ & $7.4082 \mathrm{E}+00$ & $5.64 \mathrm{E}+01$ & & & & \\
\hline 5 & $7.4082 \mathrm{E}+00$ & $8.6071 E+\infty 0$ & $1.78 \mathrm{E}+01$ & & & & \\
\hline 4 & $8.6071 \mathrm{E}+\infty 0$ & $1.0000 \mathrm{E}+01$ & $5.14 \mathrm{E}+\infty$ & & & & \\
\hline 3 & $1.0000 \mathrm{E}+01$ & $1.2214 \mathrm{E}+01$ & $3.33 \mathrm{E}+00$ & & & & \\
\hline 2 & $1.2214 \mathrm{E}+01$ & $1.4191 \mathrm{E}+01$ & $3.82 \mathrm{E}-01$ & & & & \\
\hline 1 & $1.4191 \mathrm{E}+01$ & $1.9600 \mathrm{E}+01$ & $4.73 \mathrm{E}-02$ & & & & \\
\hline
\end{tabular}


The most significant contributor to the neutron source magnitude is the alpha,n component for Pu-238. This component is approximately 75 percent of the total specific neutron source magnitude, $1.87 \mathrm{E}+4$ neutrons per second. From the photon dose rates perspective, the most significant isotope in the envelope is Pu-236. The isotope Tl-208 in the Pu-236 decay chain emits a $2.6 \mathrm{MeV}$ gamma-ray with a yield of nearly one. The source distribution of Table 8 was computed assuming the maximum activity of Tl-208 is present (which occurs after approximately 25 years of decay). The Tl-208 photons comprise essentially all of the photons in the 2 to $3 \mathrm{MeV}$ group. The total specific photon source magnitude is $7.51 \mathrm{E}+10$ photons per second.

\section{RESULTS - COMPUTED DOSE RATES}

The discussion of the MCNP transport calculations is presented in two sections - one for Hypothetical Accident Conditions (HAC) and one for Normal Conditions of Transport NCT). The package geometry is, of course, different between NCT and HAC, but as mentioned earlier, different assumptions were made regarding source location and configuration. Those assumptions are summarized in Table 9 below. Essentially, the source is placed as close to the receptor location(s) as possible. Neutron source calculations assume a $1.277 \mathrm{~cm}$ radius sphere at the theoretical pu-oxide density, with the intent of maximizing sub-critical multiplication. Photon source calculations assume thin source regions at bulk pu-oxide density, with the intent of maximizing leakage.

Appendix B gives the MCNP job names for the different calculations, and discusses the conversion factors needed to convert the MCNP results into units of $\mathrm{mrem} / \mathrm{h}$.

\section{TABLE 9. Summary of Neutron and Photon Source Configurations}

\begin{tabular}{|l|l|l|}
\hline Dose Receptor Location & \multicolumn{1}{|c|}{ Neutron Source Configuration } & \multicolumn{1}{|c|}{ Photon Source Configuration } \\
\hline Side & $11.46 \mathrm{~g} / \mathrm{cm}^{3}$ sphere; bottom, side PCV & $0.70 \mathrm{~g} / \mathrm{cm}^{3}, 1 / 4$-annulus, side of PCV \\
Bottom & $11.46 \mathrm{~g} / \mathrm{cm}^{3}$ sphere; bottom, side PCV & $0.70 \mathrm{~g} / \mathrm{cm}^{3}$ disc, bottom of PCV \\
Top & $11.46 \mathrm{~g} / \mathrm{cm}^{3}$ sphere; top, side PCV & $0.70 \mathrm{~g} / \mathrm{cm}^{3}$ disc, top of PCV \\
\hline
\end{tabular}

\section{Hypothetical Accident Conditions - Neutron Sources}

The neutron source distribution used for these calculations is shown in Table 8. Scoping calculations indicated that of the 47 groups, neutrons in Groups $7-25$ contributed $>99 \%$ of the total neutron dose, and neutrons in Groups 5-25 contributed $>99 \%$ of the total $(\mathrm{n}, \gamma)$ gamma dose. Consequently, neutron dose calculations typically used neutrons from 
Groups $7-25$ only; gamma doses from $(\mathrm{n}, \gamma)$ reactions were based on neutrons from Groups $5-25$ only.

Results from the neutron source calculations for HAC are shown in Table 10. Shown in columns 3 and 4 are the computed mean and 1-sigma uncertainty (derived from the MCNP calculations). The last column is the computed mean plus $3 \sigma$. Table 10 shows that the gamma dose from neutron induced events is negligible relative to the neutron dose.

\section{TABLE 10. Neutron Source Calculations - HAC}

\begin{tabular}{|c|c|c|c|c|}
\hline & \multirow{2}{*}{$\begin{array}{l}\text { Receptor } \\
\text { Location }\end{array}$} & \multicolumn{3}{|c|}{ DOSE (mrem/h) } \\
\hline & & Mean & 1-sigma & Mean $+3 \sigma$ \\
\hline \multirow{3}{*}{ Neutron } & side @1 m & 2.286 & $9.14 \mathrm{E}-04$ & 2.289 \\
\hline & bottom@1m & 1.887 & $7.55 \mathrm{E}-04$ & 1.890 \\
\hline & top@1m & 0.708 & 1.42E-03 & 0.713 \\
\hline \multirow{3}{*}{$(\mathbf{n}, \gamma)$} & side @1 m & $7.461 \mathrm{E}-03$ & $1.34 \mathrm{E}-05$ & $7.502 \mathrm{E}-03$ \\
\hline & bottom@1m & $5.109 \mathrm{E}-03$ & 8.17E-06 & $5.134 \mathrm{E}-03$ \\
\hline & top@ $1 \mathrm{~m}$ & $1.904 \mathrm{E}-03$ & $1.07 \mathrm{E}-05$ & $1.936 \mathrm{E}-03$ \\
\hline
\end{tabular}

\section{Hypothetical Accident Conditions - Photon Sources}

The photon source distribution used for these calculations is shown in Table 8. Scoping calculations indicated that of the 20 groups, photons in Groups $8-18$ contributed $>99 \%$ of the total photon dose. Consequently, photon source calculations used photons from Groups 8-18 only. To ensure proper sampling of the photon source, two blocks of photon transport calculations were performed - one block with photon source of Groups $16-18$, and one block with the photons source of Groups $8-15$. Results from the photon source calculations for HAC are shown in Table 11.

\section{TABLE 11. Photon Source Calculations - HAC}

\begin{tabular}{|c|c|c|c|c|}
\hline \multirow{2}{*}{$\begin{array}{l}\text { Receptor } \\
\text { Location }\end{array}$} & \multirow{2}{*}{$\begin{array}{l}\text { Photon } \\
\text { Source }\end{array}$} & \multicolumn{3}{|c|}{ DOSE (mrem/h) } \\
\hline & & Mean & 1-sigma & Mean $+3 \sigma$ \\
\hline Side @ $1 \mathrm{~m}$ & $\begin{array}{l}\text { Groups } 16-18 \\
\text { Groups } 8-15\end{array}$ & $\begin{array}{l}2.814 \\
1.665\end{array}$ & $\begin{array}{l}1.52 \mathrm{E}-02 \\
8.33 \mathrm{E}-04\end{array}$ & $\begin{array}{l}2.860 \\
1.668\end{array}$ \\
\hline Bottom@1 m & $\begin{array}{l}\text { Groups } 16-18 \\
\text { Groups } 8-15\end{array}$ & $\begin{array}{l}1.928 \\
1.374 \\
\end{array}$ & $\begin{array}{l}1.29 \mathrm{E}-02 \\
8.24 \mathrm{E}-04\end{array}$ & $\begin{array}{l}1.967 \\
1.377\end{array}$ \\
\hline Top@ @ $1 \mathrm{~m}$ & $\begin{array}{l}\text { Groups 16 -18 } \\
\text { Groups 8 - } 15\end{array}$ & $\begin{array}{l}0.0008 \\
0.1534\end{array}$ & $\begin{array}{l}6.60 \mathrm{E}-05 \\
3.91 \mathrm{E}-03 \\
\end{array}$ & $\begin{array}{c}0.00100 \\
0.166 \\
\end{array}$ \\
\hline
\end{tabular}




\section{Hypothetical Accident Conditions - SUMMARY}

Table 12 summarizes results for the HAC cases. The $1 \sigma$ uncertainties on the total gamma dose in Table 12 are calculated using the square-root-sum-of-squares method for the three components (Groups 8-15, Groups 16-18, and the (n, $\gamma$ ) events). One can note that the contribution from $(n, \gamma)$ events is negligible since it is less than the uncertainty associated with the photon source calculations.

\section{TABLE 12. HAC Summary}

\begin{tabular}{|c|c|c|c|c|}
\hline & \multirow{2}{*}{$\begin{array}{l}\text { Receptor } \\
\text { Location }\end{array}$} & \multicolumn{3}{|c|}{ DOSE (mrem/h) } \\
\hline & & Mean & 1-sigma & Mean $+3 \sigma$ \\
\hline \multirow{3}{*}{ Neutron } & side@ $1 \mathrm{~m}$ & 2.286 & $9.14 \mathrm{E}-04$ & 2.289 \\
\hline & bottom @ $1 \mathrm{~m}$ & 1.887 & $7.55 \mathrm{E}-04$ & 1.890 \\
\hline & top@1m & 0.708 & $1.42 \mathrm{E}-03$ & 0.713 \\
\hline \multirow{3}{*}{ Photon } & side@1 m & 4.486 & $1.52 \mathrm{E}-02$ & 4.532 \\
\hline & bottom@1m & 3.307 & $1.29 \mathrm{E}-02$ & 3.346 \\
\hline & top @ $1 \mathrm{~m}$ & 0.1561 & $3.91 \mathrm{E}-03$ & 0.168 \\
\hline
\end{tabular}

\section{Normal Conditions of Transport - Neutron Sources}

The NCT calculations used the same abbreviated neutron source as the HAC calculations. Neutron dose calculations used neutrons from Groups $7-25$ only; gamma doses from $(\mathrm{n}, \gamma)$ reactions were based on neutrons from Groups $5-25$ only. Results from the neutron source calculations for NCT are shown in Table 13.

An unusual result was noted when comparing Tables 10 and 13. Neutron doses at 1 meter are higher for NCT $(0.754 \mathrm{mrem} / \mathrm{hr})$ than for HAC $(0.713 \mathrm{mrem} / \mathrm{h})$ even though there is more shielding present under NCT, and the distance between the payload and the (1 meter) dose receptor location is greater for NCT than HAC. The explantion lies in the fact that the additional shielding materials present under NCT serve as a neutron scattering source - a source that is not present for HAC. This scattering source is large enough to offset the effect of the additional shielding. Additional information on this phenomena can be obtained from a review of the MCNP detector tally edits. Those edits show how each individual cell's contribution to the dose changes between NCT and HAC. 
TABLE 13. Neutron Source Calculations - NCT

\begin{tabular}{|c|c|c|c|c|}
\hline & \multicolumn{3}{|c|}{ DOSE (mrem/h) } \\
\hline & & Mean & 1-sigma & Mean $+3 \sigma$ \\
\hline \multirow{6}{*}{ Neutron } & side @ surface & 72.48 & 0.2682 & 73.29 \\
\hline & bottom @ surface & 54.64 & 0.4153 & 55.89 \\
\hline & top @ surface & 21.03 & 0.07783 & 21.27 \\
\hline & side @1 m & 1.740 & 0.0006962 & 1.743 \\
\hline & bottom@1m & 1.463 & 0.0007314 & 1.466 \\
\hline & top @ $1 \mathrm{~m}$ & 0.7525 & 0.0003762 & 0.7537 \\
\hline \multirow{6}{*}{$(\mathbf{n}, \gamma)$} & side@ @urface & 0.1745 & 0.003611 & 0.1853 \\
\hline & bottom@ @urface & 0.1949 & 0.002398 & 0.2022 \\
\hline & top@surface & $6.825 \mathrm{E}-02$ & $3.412 \mathrm{E}-04$ & $6.927 \mathrm{E}-02$ \\
\hline & side @ $1 \mathrm{~m}$ & $4.030 \mathrm{E}-03$ & $9.672 \mathrm{E}-06$ & $4.060 \mathrm{E}-03$ \\
\hline & bottom@1m & 4.395E-03 & $1.846 \mathrm{E}-05$ & $4.451 \mathrm{E}-03$ \\
\hline & top @ $1 \mathrm{~m}$ & $2.033 \mathrm{E}-03$ & $2.439 \mathrm{E}-06$ & $2.041 \mathrm{E}-03$ \\
\hline
\end{tabular}

\section{Normal Conditions of Transport - Photon Sources}

The photon source calculations for NCT used photons from only Groups 8-15. HAC conditions assumed significantly less shielding materials than will be present under NCT. For HAC, the low energy photons in Groups $16-18$ were numerous enough that the small fraction that did manage to penetrate the PCV and SCV make a significant contribution to the dose. The additional intervening materials present for NCT effectively eliminates the contribution from those energy groups. (Evidence of this is seen in Table 11 where the contribution to the dose above the package from Groups $16-$ 18 is negligible. Due to the PCV and SCV closures (see, for example, Figure 3) there is more shielding above the package than on its side or bottom.) Results from the photon source calculations for HAC are shown in Table 14.

TABLE 14. Photon Source Calculations - NCT

\begin{tabular}{|c|c|c|c|c|}
\hline & \multicolumn{3}{|c|}{ DOSE (mrem/h) } \\
\hline & & Mean & 1-sigma & Mean $+3 \sigma$ \\
\hline \multirow{6}{*}{$\begin{array}{l}\text { Photon } \\
\text { Source }\end{array}$} & side @ surface & 12.52 & 0.2816 & 13.37 \\
\hline & bottom @ surface & 24.61 & 0.2141 & 25.26 \\
\hline & top@ @urface & 2.318 & $2.457 \mathrm{E}-02$ & 2.392 \\
\hline & side @ $1 \mathrm{~m}$ & 0.4226 & $1.268 \mathrm{E}-03$ & 0.4264 \\
\hline & bottom @1 m & 0.7084 & $6.376 \mathrm{E}-04$ & 0.7104 \\
\hline & top @ 1 m & 0.1097 & $9.872 \mathrm{E}-04$ & 0.1127 \\
\hline
\end{tabular}




\section{Normal Conditions of Transport - SUMMARY}

Table 15 summarizes results for the NCT cases. The $1 \sigma$ uncertainties on the total gamma dose in Table 15 are calculated using the square-root-sum-of-squares method for the two components (Groups $8-15$ and the $(n, \gamma)$ events). As noted with the HAC cases, the contribution from $(\mathrm{n}, \gamma)$ events is negligible.

\section{TABLE 15. NCT Summary}

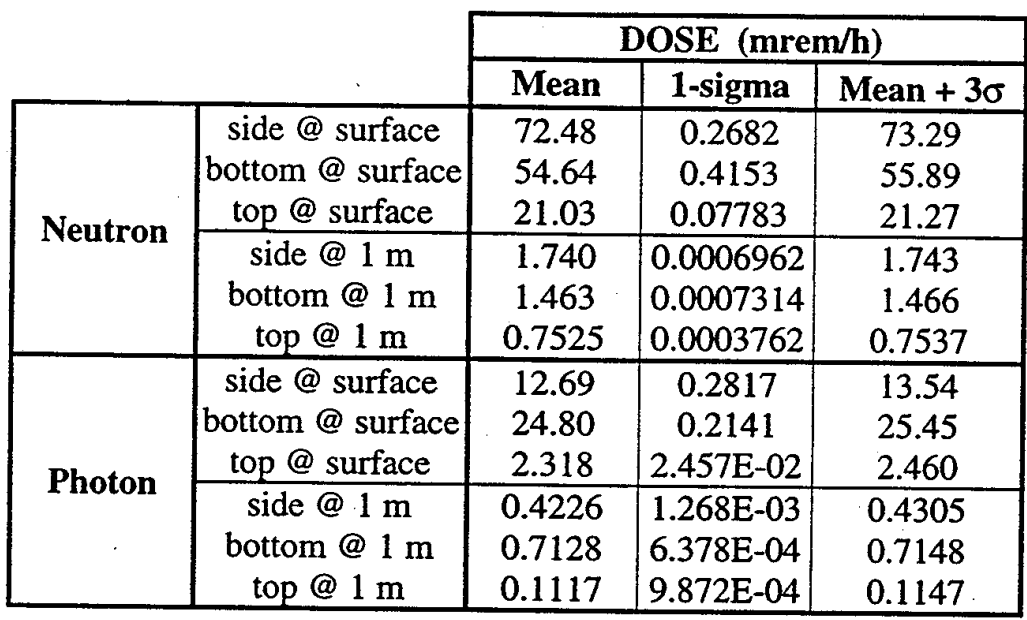

\section{CONCLUSIONS}

The results from Tables 12 and 15 are combined and appear in Table 2. They show that the payload contents of Table 1 (100 gram actinide limit) in the 9968 package satisfy the regulatory requirements for a non-exclusive use package. A substantial margin is noted between the regulatory limit and the computed results even though the source term was assumed to be $168 \%$ of the nominal source.

The transport index based upon shielding considerations (the maximum radiation level in $\mathrm{mrem} / \mathrm{hr}$ at 1 meter, rounded up to the next tenth) for this payload in the 9968 package is 2.2 (see Table 2). 
WSRC-TR-98-00279

Engineered Equipment and Systems Department

Dose Calculation for Pu-238 Oxide Payload in 9968 Shipping Container

N-CLC-G-00067

WSMSC-98-0207

Revision 0

Figure 1. Schematic of 9968 Shipping Package

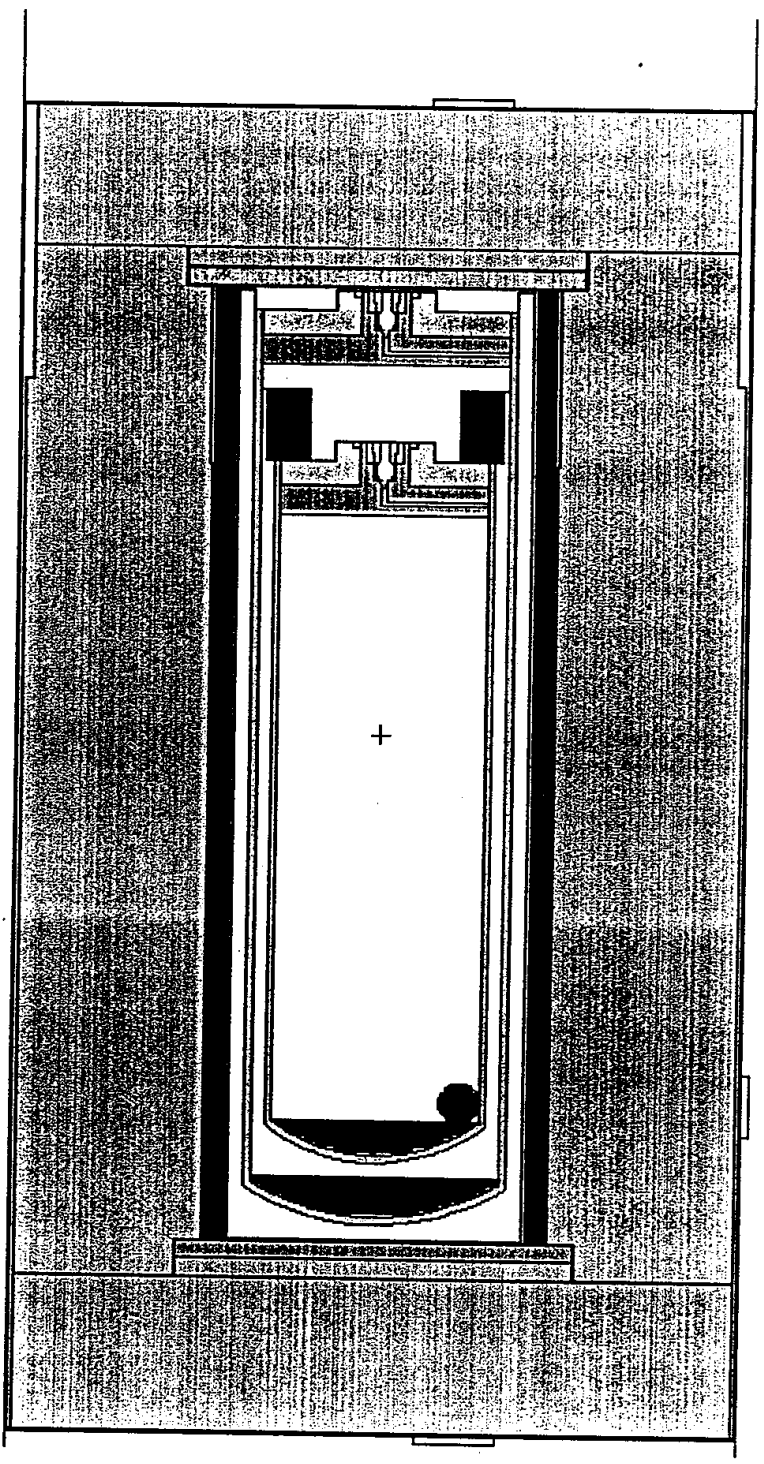


WSRC-TR-98-00279

Engineered Equipment and Systems Department

Dose Calculation for Pu-238 Oxide Payload in 9968 Shipping Container

N-CLC-G-00067

WSMSC-98-0207

Revision 0

Figure 2. Detail of PCV and SCV Closures

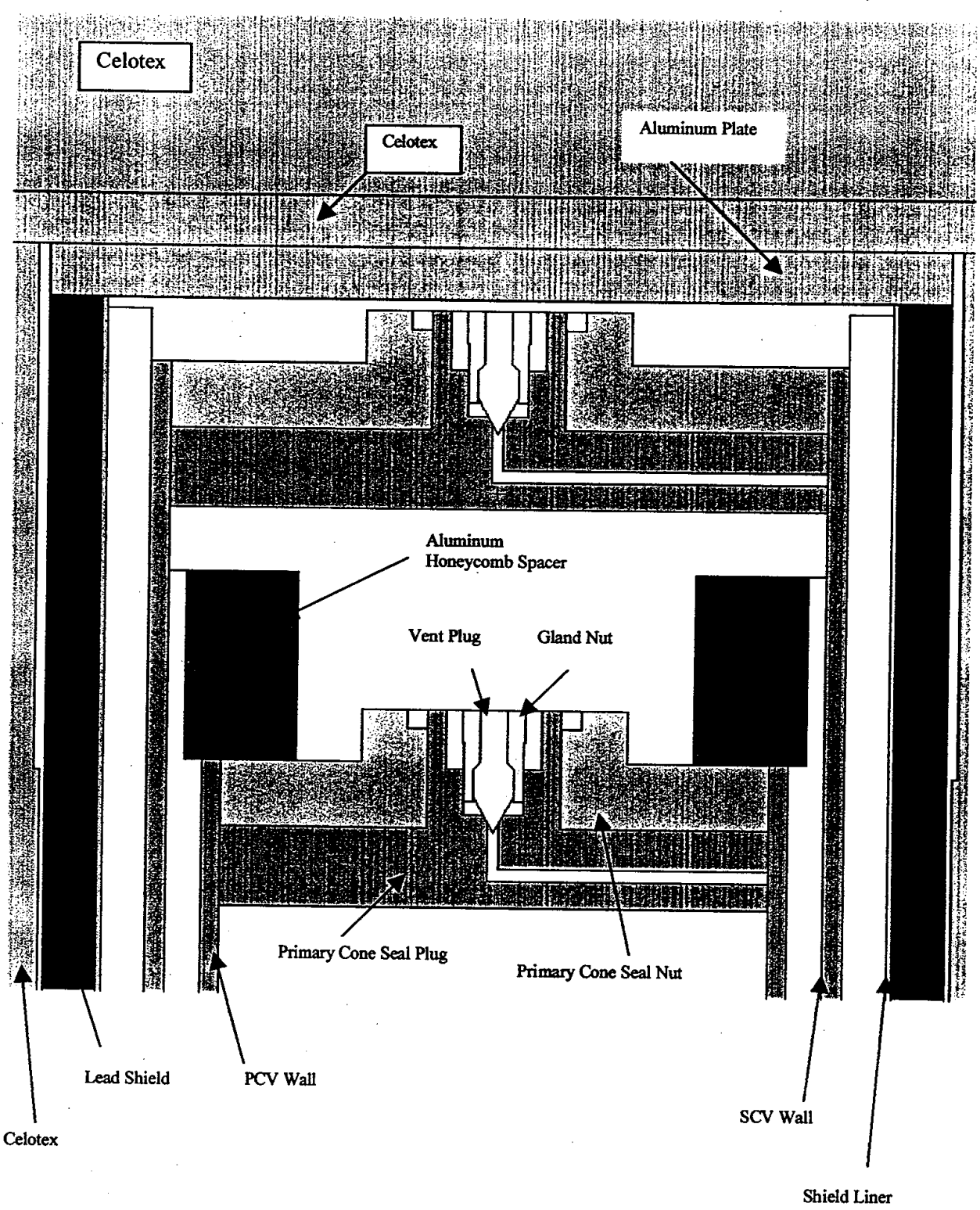


WSRC-TR-98-00279

Engineered Equipment and Systems Department

Dose Calculation for Pu-238 Oxide Payload in 9968 Shipping Container

N-CLC-G-00067

WSMSC-98-0207

Revision 0

FIGURE 3

PCV/SCV CLOSURE GEOMETRY (Dimensions in cm)

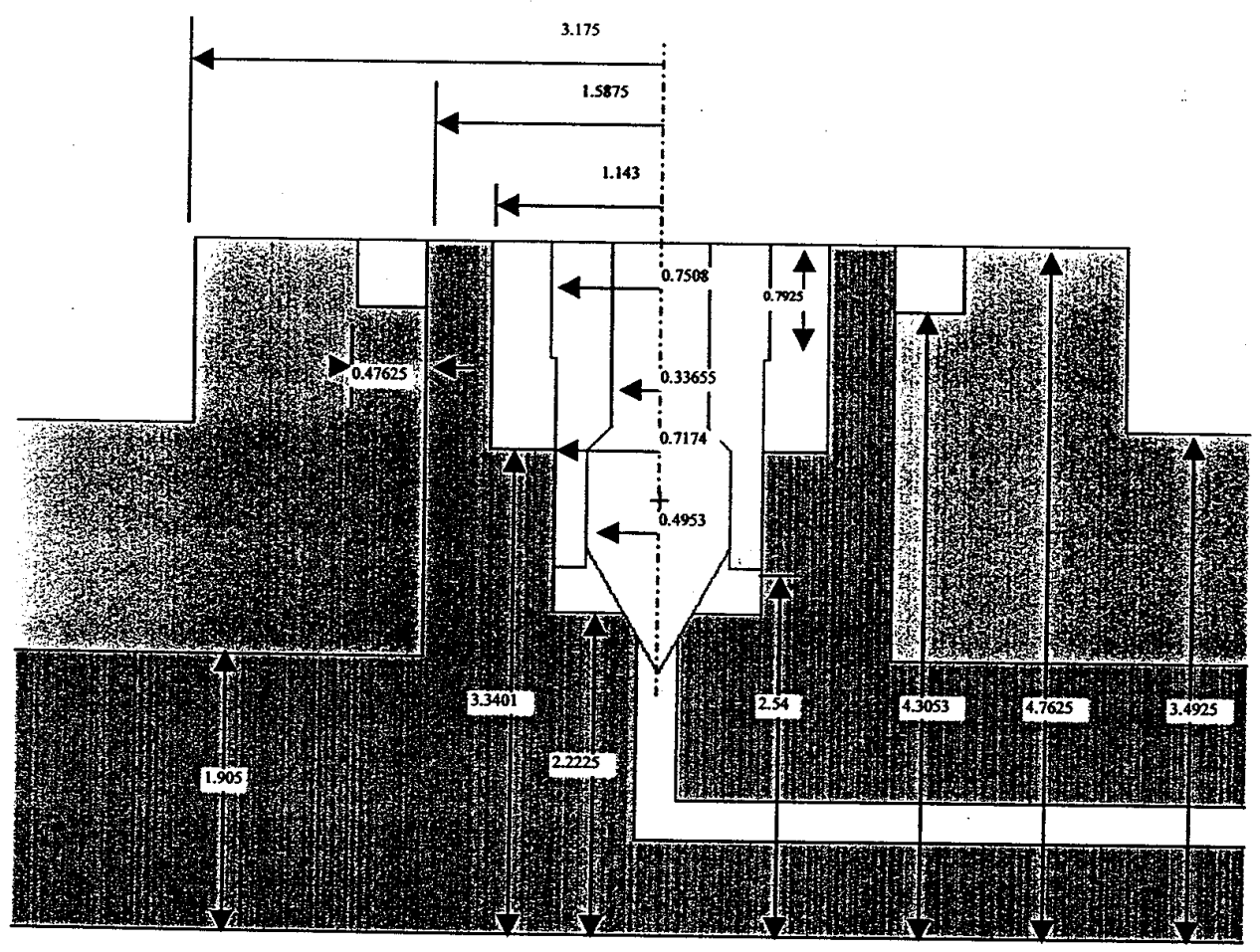


WSRC-TR-98-00279

Engineered Equipment and Systems Department

Dose Calculation for Pu-238 Oxide Payload in 9968 Shipping Container

N-CLC-G-00067

WSMSC-98-0207

Figure 4. Geometry for Gamma Source Calculations, Dose Locations on Side
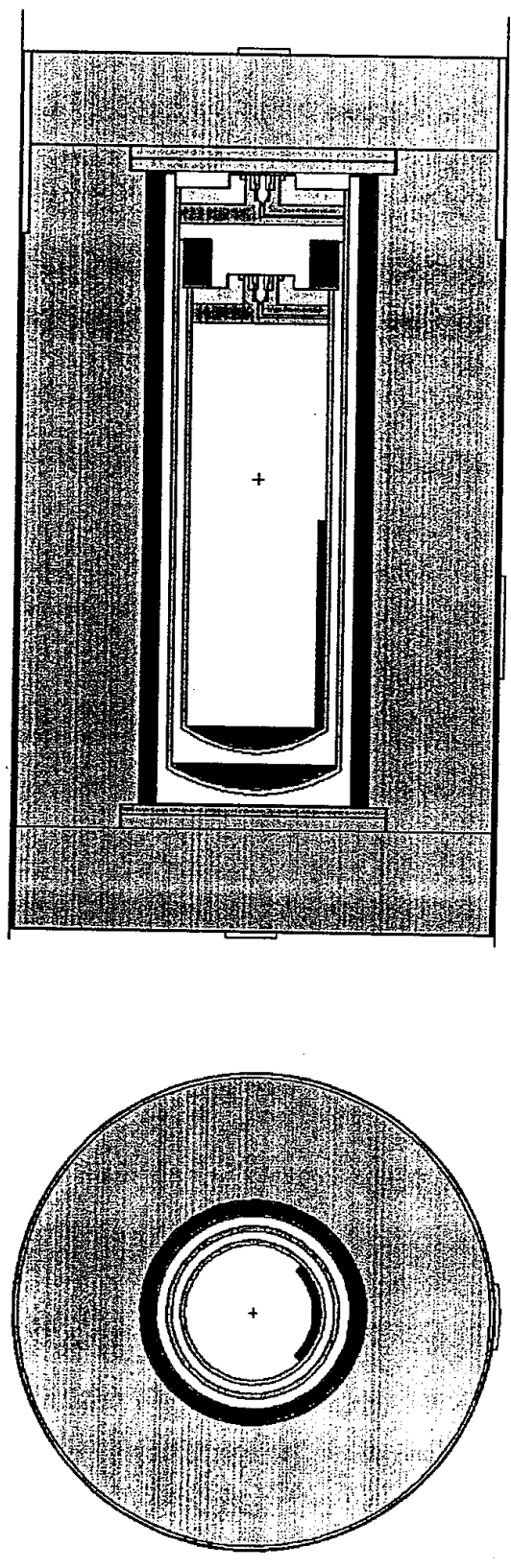


\section{Figure 5. Geometry Used for Hypothetical Accident Conditions}

(Disc Gamma Source at Top of PCV)

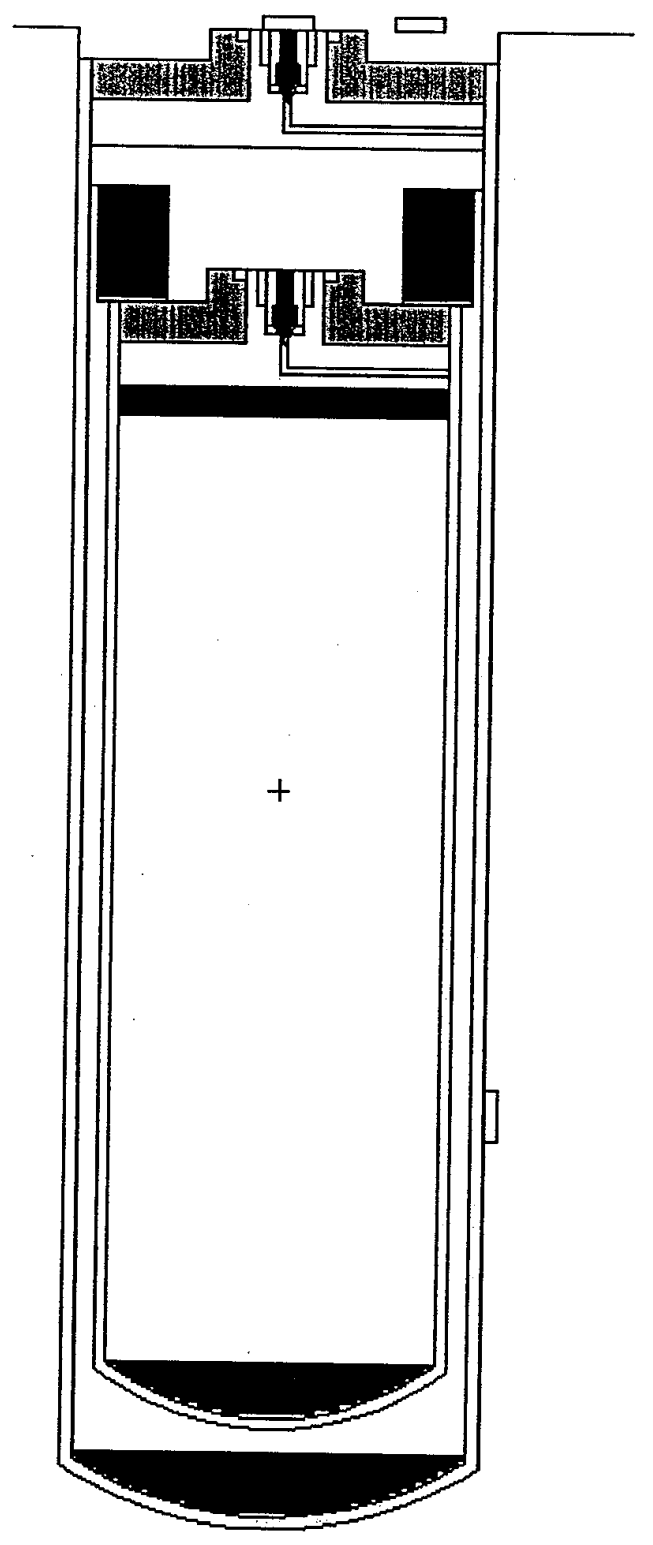


WSRC-TR-98-00279

Engineered Equipment and Systems Department

Dose Calculation for Pu-238 Oxide Payload

in 9968 Shipping Container

N-CLC-G-00067

WSMSC-98-0207

Revision 0

\section{REFERENCES}

1. J. F. Briesmeister, Ed., "MCNP - A General Monte Carlo N-Particle Transport Code, Version 4B," LA-12625-M, Los Alamos National Laboratory, March 1997

2. ANSI/ANS-6.1.1-1977, "Neutron and Gamma-Ray Fluence-to-Dose Factors," 1977.

3. O. W. Hermann and R. M. Westfall, "ORIGEN-S: Scale System Module To Calculate Fuel Depletion, Actinide Transmutation, Fission Product Buildup And Decay, And Associated Radiation Source Terms," NUREG/CR-0200, Revision 5, Volume 2, Section F7 (ORNL/NUREG/CSD-2/V2/R5), Computational Physics and Engineering Division, Oak Ridge National Laboratory, Oak Ridge, TN, March 1997.

4. Frost, R. L., "RASTA - Radiation Source Term Analysis, User Guide," WSMSCRT-97-0013, November 1997.

5. "Mechanical and Physical Properties of Steels for Nuclear Applications," United States Steel, 525 William Penn Place, Pittsburgh, Pennsylvania 15230 (1967).

6. C. D. Harmon, II, Robert D. Busch, J. F. Briesmeister, and R. A. Forster, LA-12827M, UC-714, Criticality Calculations with MCNP: A Primer, p. C-3, August 1994. 
WSRC-TR-98-00279

Engineered Equipment and Systems Department

Dose Calculation for Pu-238 Oxide Payload

in 9968 Shipping Container

N-CLC-G-00067

WSMSC-98-0207

Revision 0

APPENDIX A

\section{SAMPLE INPUT DECKS}

A.1. ORIGEN-S Input Deck

A.2. RASTA Input Deck

A.3. MCNP Input (HAC, Gamma Source Groups 16-18, Bottom Dose) Deck 28

A.4. MCNP Input (HAC, Gamma Source Groups $8-15$, Side Dose) Deck

A.5. MCNP Input (NCT, Neutron Source Groups 7 - 25, Top Doses) Deck 
WSRC-TR-98-00279

Engineered Equipment and Systems Department

Dose Calculation for Pu-238 Oxide Payload in 9968 Shipping Container

N-CLC-G-00067

WSMSC-98-0207

\section{A.1. ORIGEN-S Input Deck:}

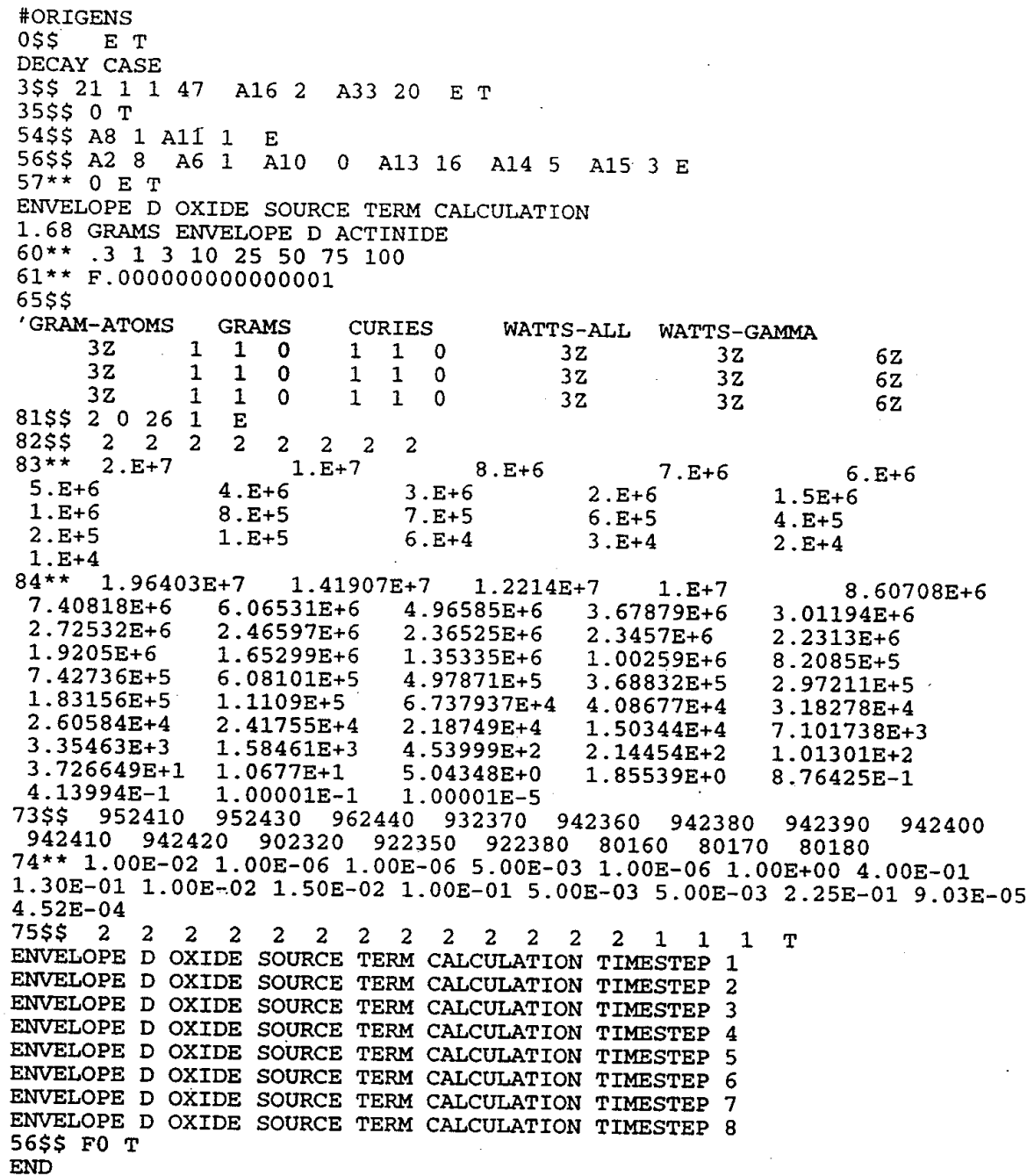


WSRC-TR-98-00279

Engineered Equipment and Systems Department

Dose Calculation for Pu-238 Oxide Payload

N-CLC-G-00067

in 9968 Shipping Container

\author{
WSMSC-98-0207
}

Revision 0

\title{
A.2. RASTA Input Deck:
}

OXIDE SOURCE TERM CALCULATION

1.68 GRAMS ENVELOPE D ACTINIDE

$\begin{array}{lllllll}-1 & -1 & 1 & 0 & 0 & 0 & 0\end{array}$

331

$812080 \quad 6.47 \mathrm{E}-06$

$8221201.80 \mathrm{E}-05$

/ $8321201.80 \mathrm{E}-05$

$8421211.15 \mathrm{E}-05$

/ 842160 1.80E-05

862200 1.80E-05

$8822401.80 \mathrm{E}-05$

$8822801.10 \mathrm{E}-08$

$8922801.10 \mathrm{E}-08$

$9022801.80 \mathrm{E}-05$

$9023001.74 \mathrm{E}-06$

$9023101.33 \mathrm{E}-08$

$9023201.10 \mathrm{E}-08$

$9023401.68 \mathrm{E}-09$

$9123305.38 \mathrm{E}-06$

$9123411.68 \mathrm{E}-09$

$9123402.19 \mathrm{E}-12$

$9223201.84 \mathrm{E}-05$

$9223301.92 \mathrm{E}-09$

$9223403.34 \mathrm{E}-03$

$9223501.33 \mathrm{E}-08$

$9223608.69 \mathrm{E}-08$

$9223702.44 \mathrm{E}-05$

$9223801.68 \mathrm{E}-09$

$9323705.38 \mathrm{E}-06$

$9323902.00 \mathrm{E}-07$

$9423605.23 \mathrm{E}-04$

$9423801.71 E+01$

$9423902.48 \mathrm{E}-02$

$9424002.95 \mathrm{E}-02$

$9424101.03 \mathrm{E}+00$

$9424205.93 E-05$

$9524106.13 E-02$

$952430 \quad 2.00 \mathrm{E}-07$

$9624408.10 \mathrm{E}-05$

32

$801602.25 E-01$

$801709.03 E-05$

$801804.52 \mathrm{E}-04$ 
WSRC-TR-98-00279

Engineered Equipment and Systems Department

Dose Calculation for Pu-238 Oxide Payload

N-CLC-G-00067

in 9968 Shipping Container

WSMSC-98.0207

Revision 0

\section{A.3. MCNP Input (HAC, Gamma Source Groups 16 - 18, Bottom Dose) Deck:}

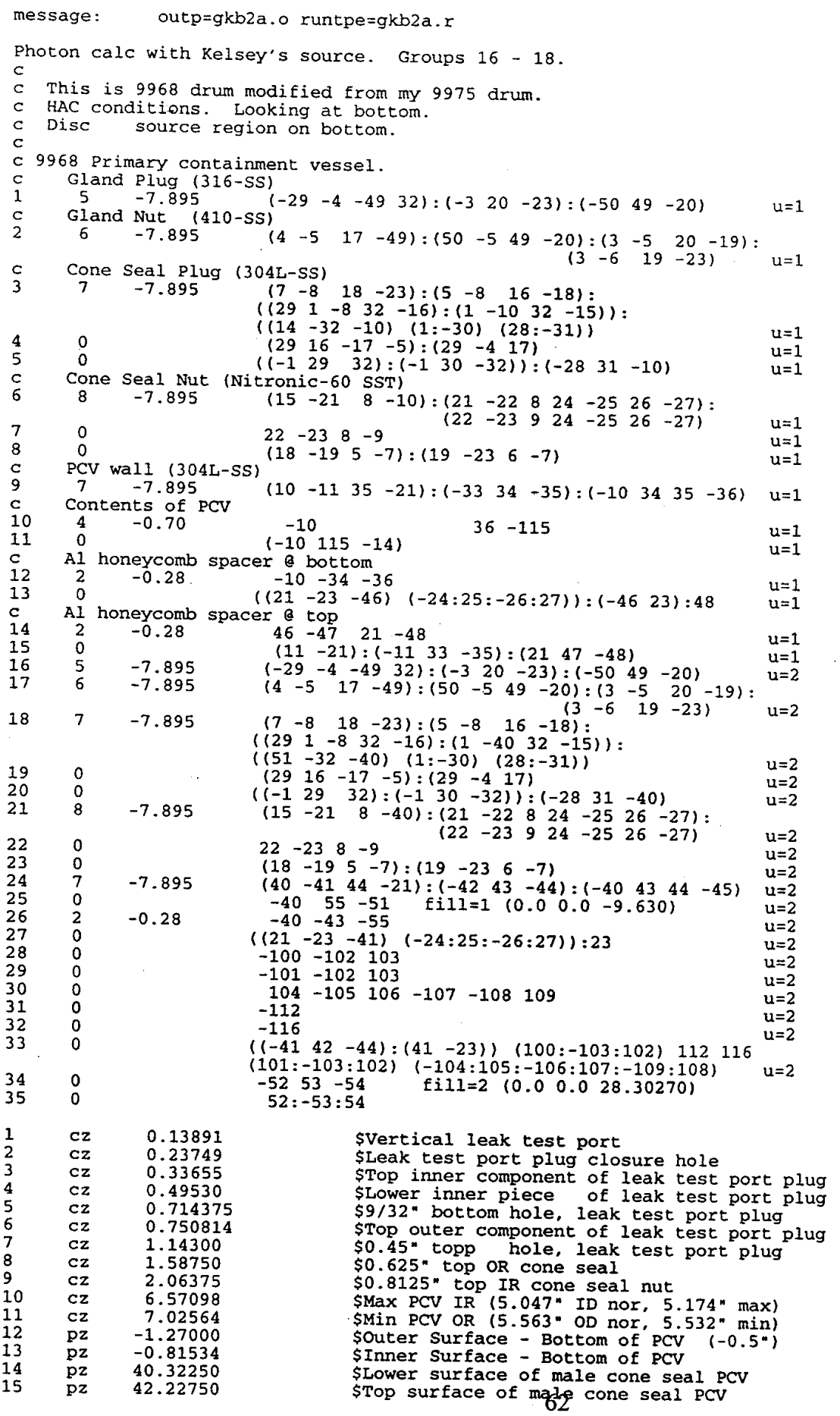


WSRC-TR-98-00279

Engineered Equipment and Systems Department

Dose Calculation for Pu-238 Oxide Payload in 9968 Shipping Container

N-CLC-G-00067

WSMSC-98-0207

Revision 0

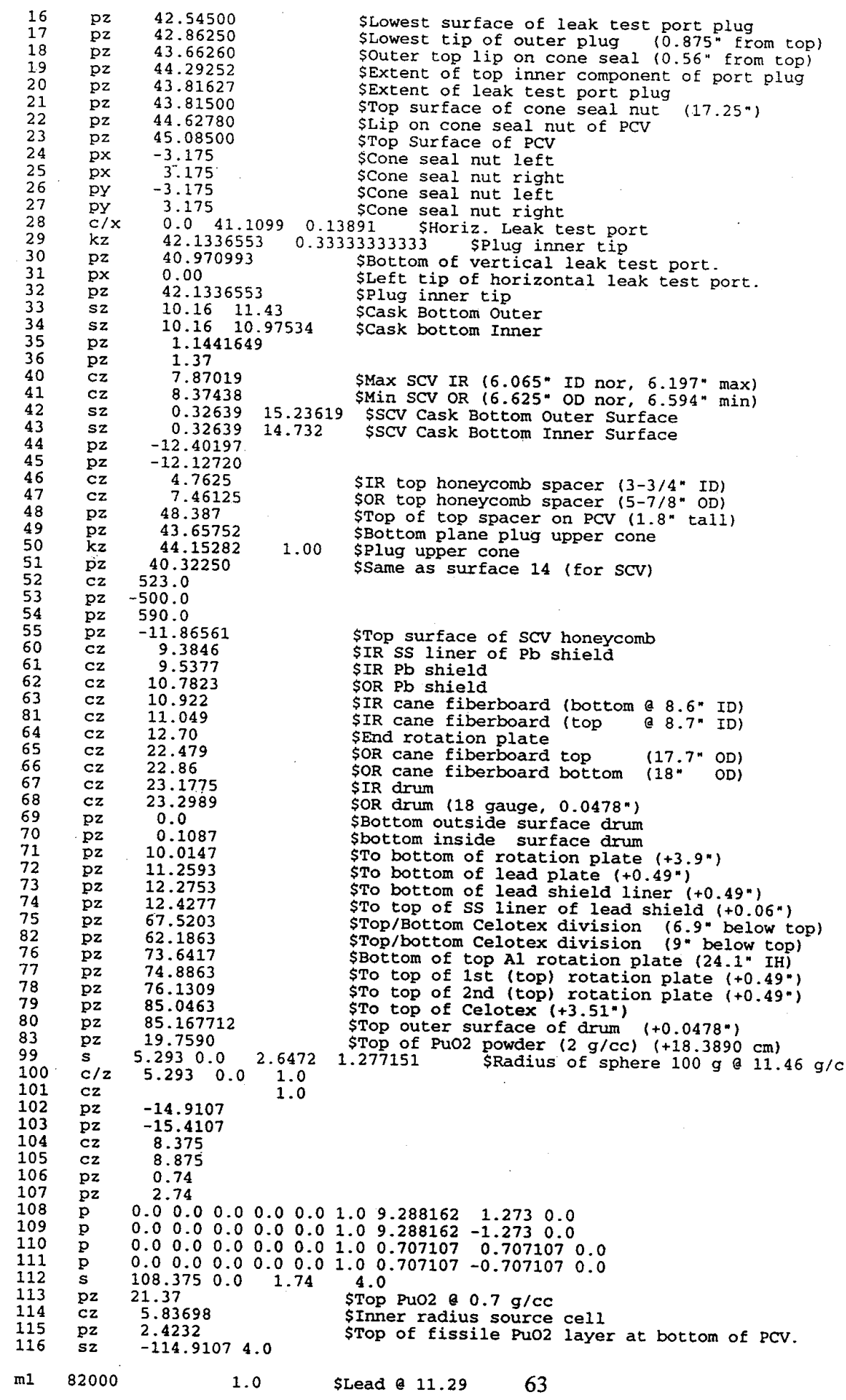


Dose Calculation for Pu-238 Oxide Payload in 9968 Shipping Container

N-CLC-G-00067

WSMSC-98-0207

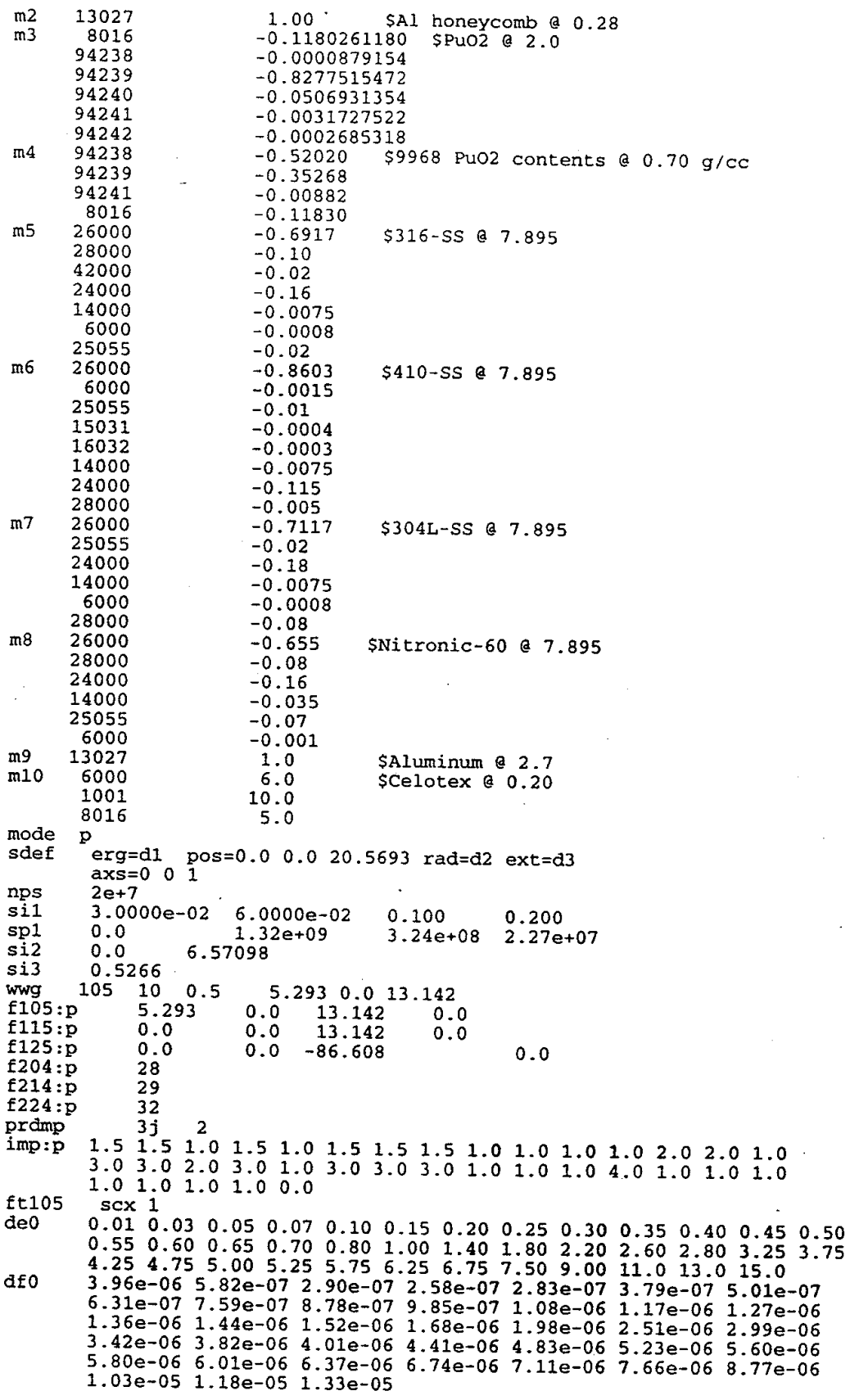


WSRC-TR-98-00279

Engineered Equipment and Systems Department

Dose Calculation for Pu-238 Oxide Payload

N-CLC-G-00067

in 9968 Shipping Container

WSMSC-98-0207

Revision 0

\section{A.4. MCNP Input (HAC, Gamma Source Groups 8 - 15, Side Dose) Deck:}

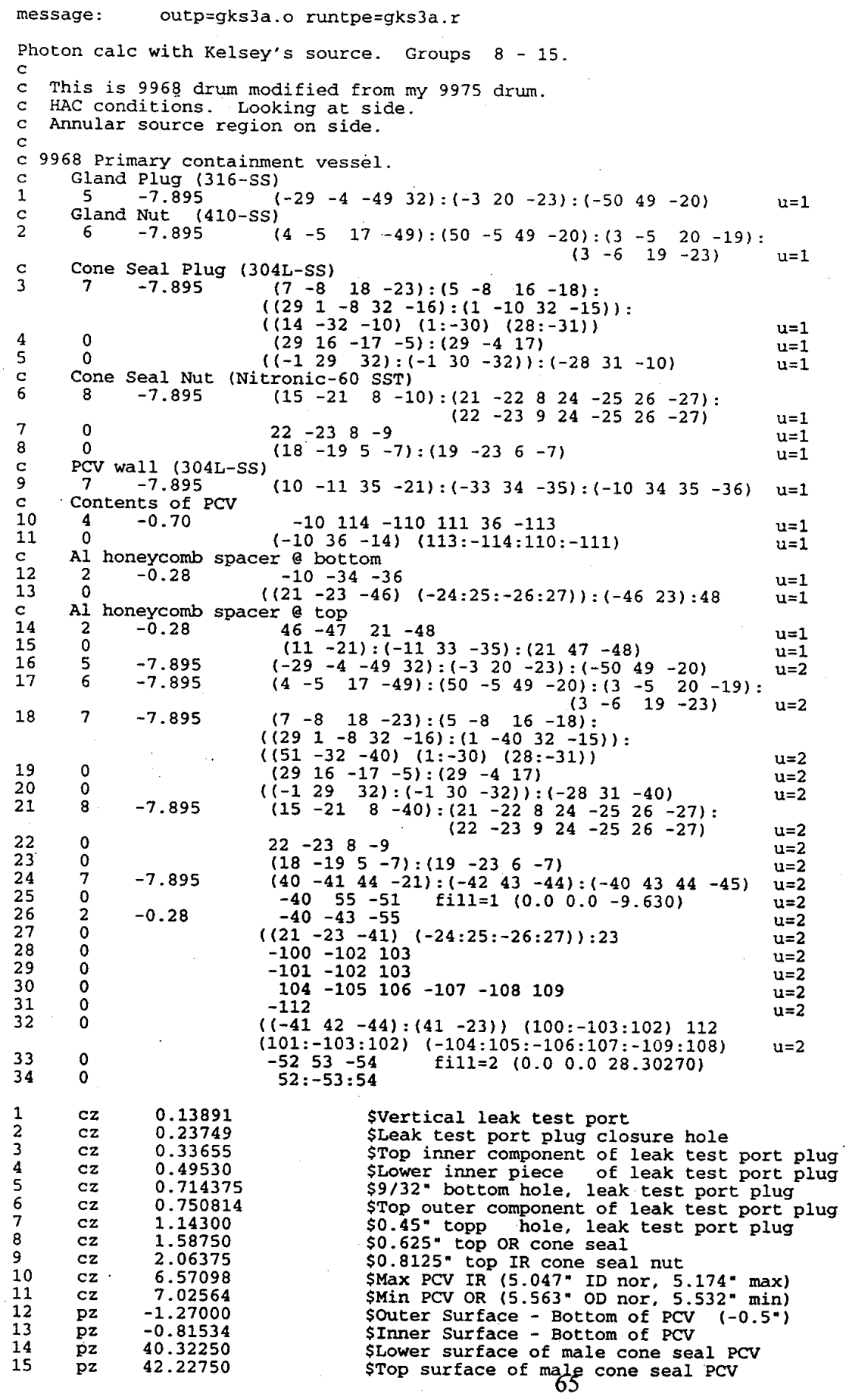


WSRC-TR-98-00279

Engineered Equipment and Systems Department

Dose Calculation for Pu-238 Oxide Payload in 9968 Shipping Container

N-CLC-G-00067

WSMSC-98-0207

Revision 0

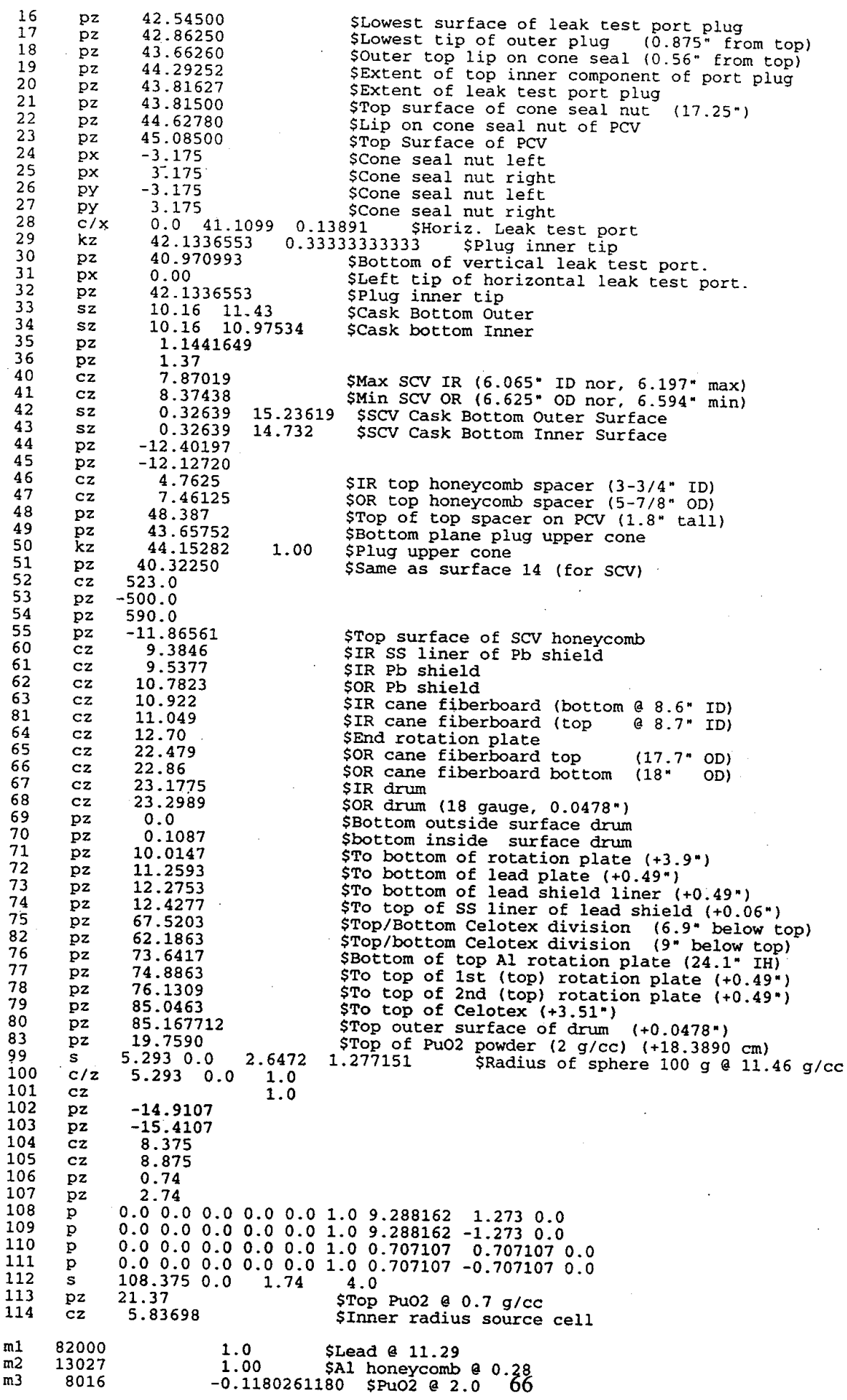


WSRC-TR-98-00279

Engineered Equipment and Systems Department

Dose Calculation for Pu-238 Oxide Payload in 9968 Shipping Container

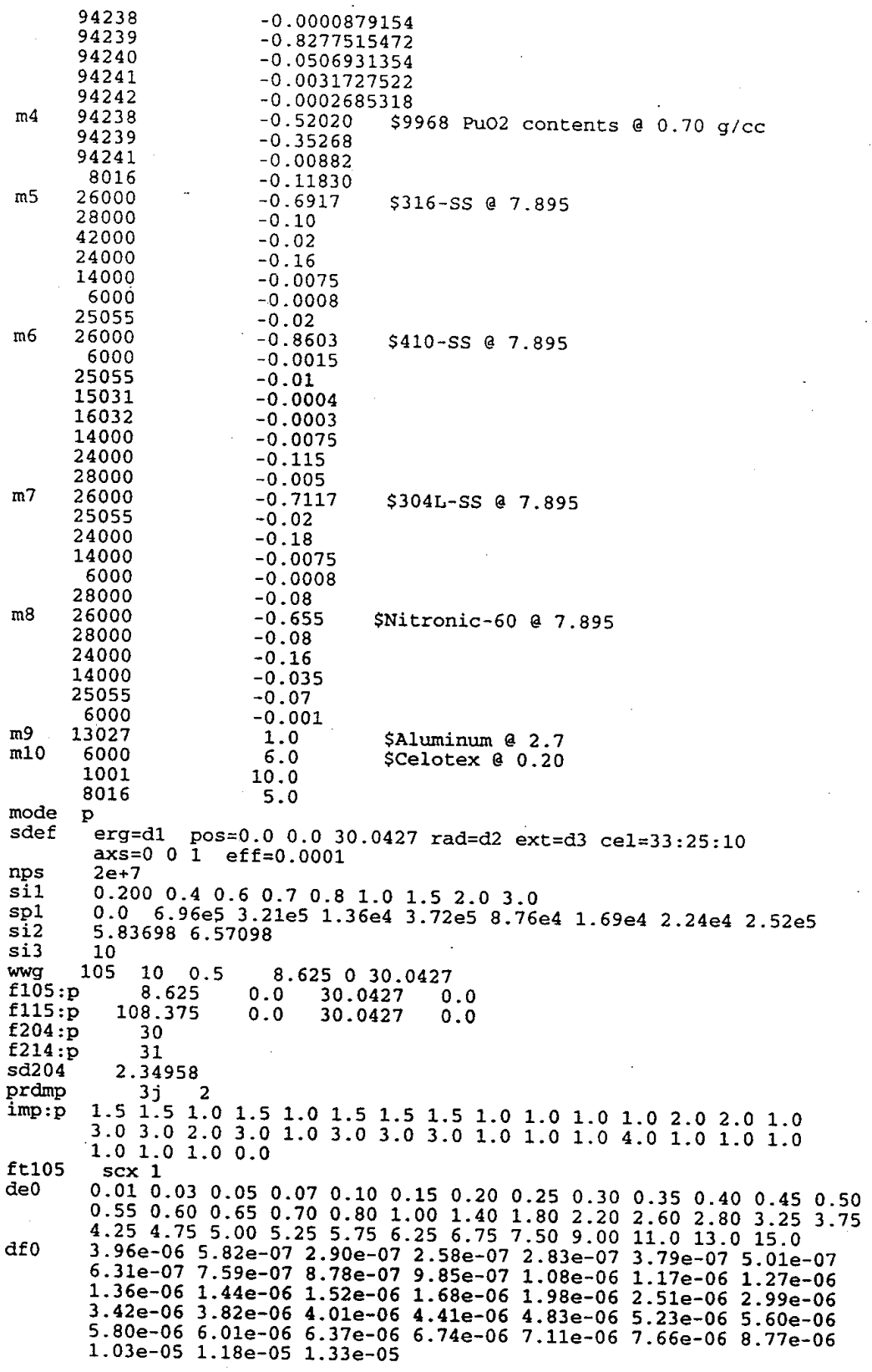

N-CLC-G-00067

WSMSC-98-0207

Revision 0 
WSRC-TR-98-00279

Engineered Equipment and Systems Department

Dose Calculation for Pu-238 Oxide Payload

in 9968 Shipping Container

N-CLC-G-00067

WSMSC-98-0207

Revision 0

\section{A.5. MCNP Input (NCT, Neutron Source Groups 7 - 25, Top Doses) Deck:}

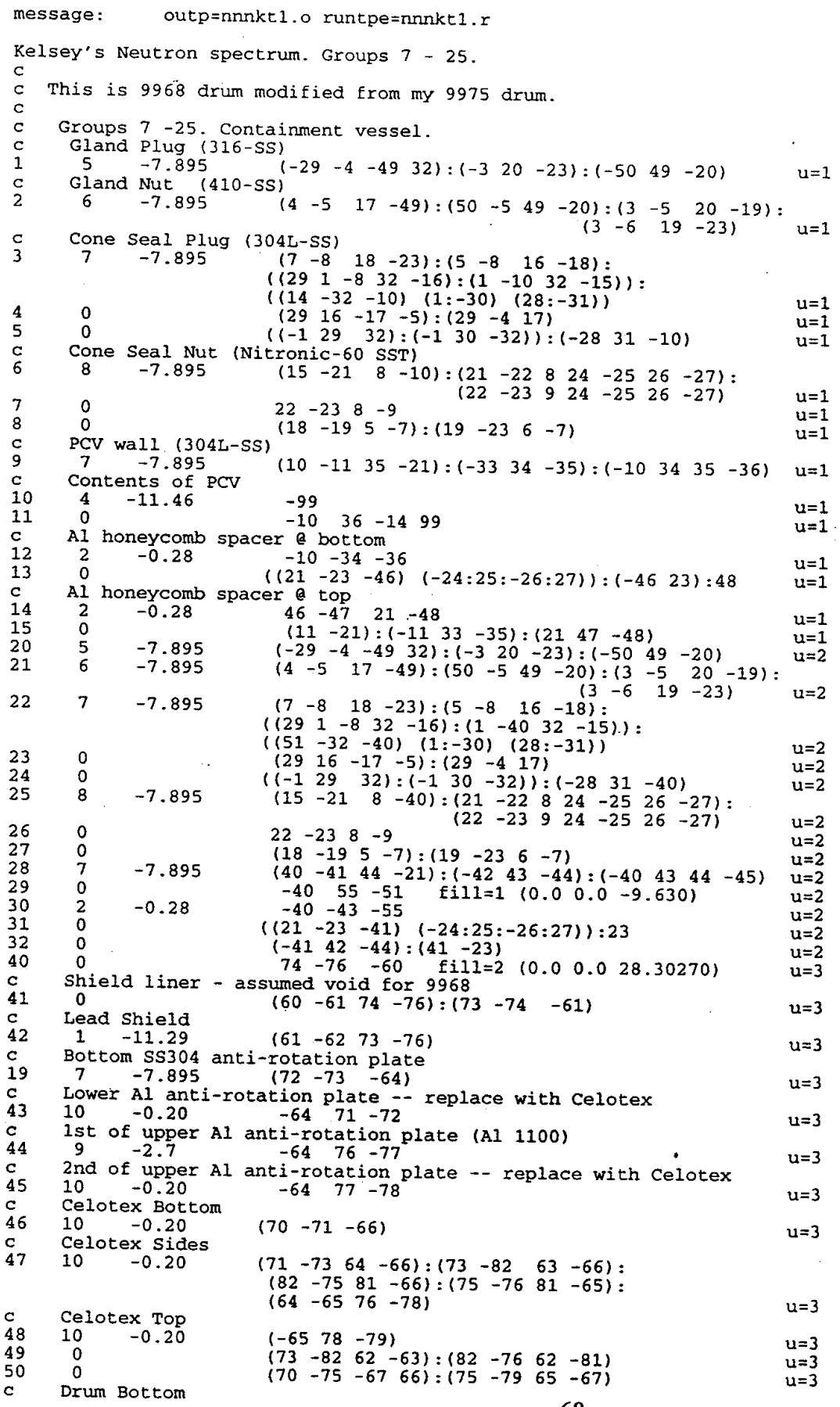


WSRC-TR-98-00279

Engineered Equipment and Systems Department

Dose Calculation for Pú-238 Oxide Payload in 9968 Shipping Container

N-CLC-G-00067

WSMSC-98-0207

Revision 0

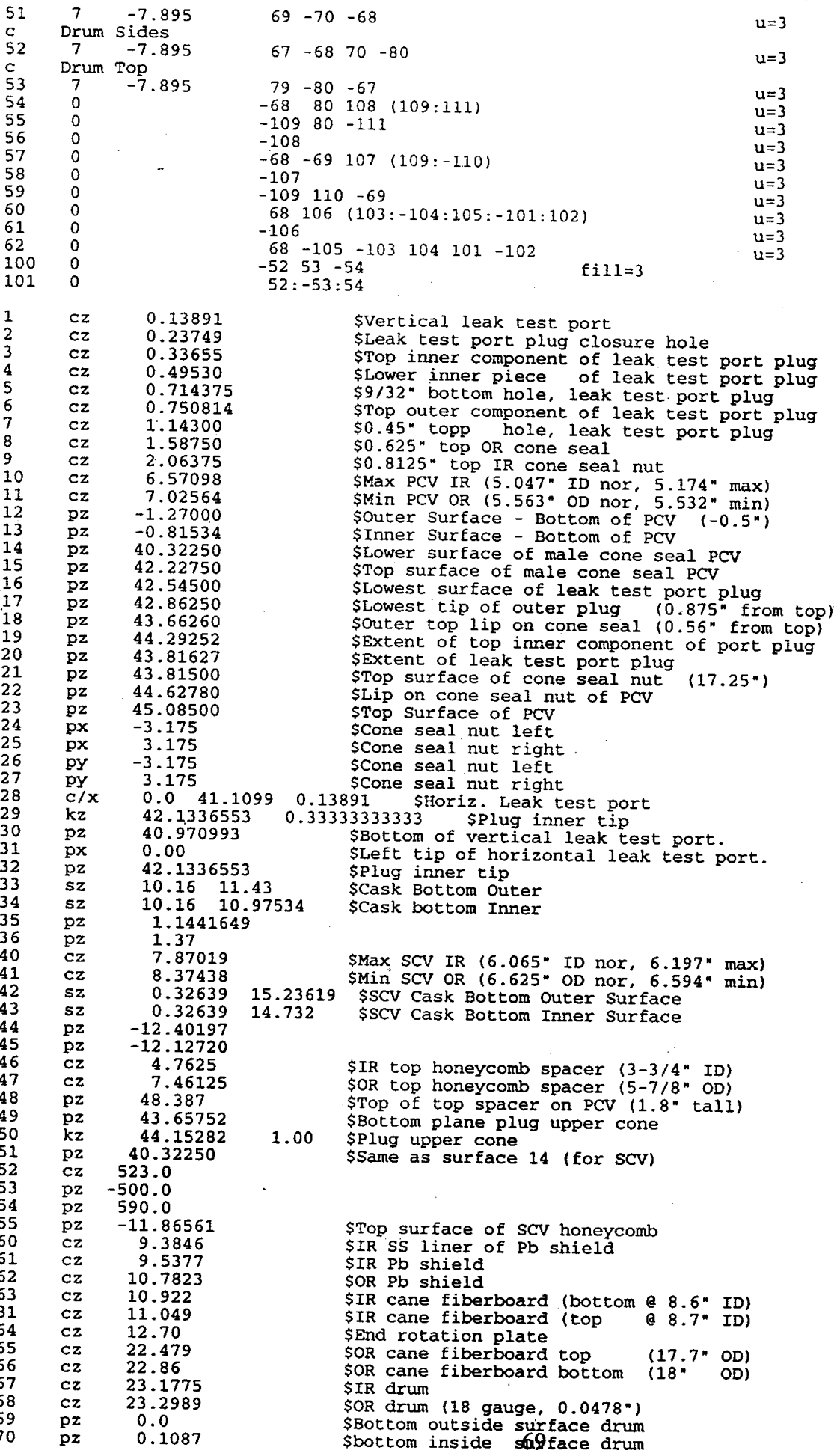


WSRC-TR-98-00279

Engineered Equipment and Systems Department

Dose Calculation for Pu-238 Oxide Payload in 9968 Shipping Container

N-CLC-G-00067

WSMSC-98-0207

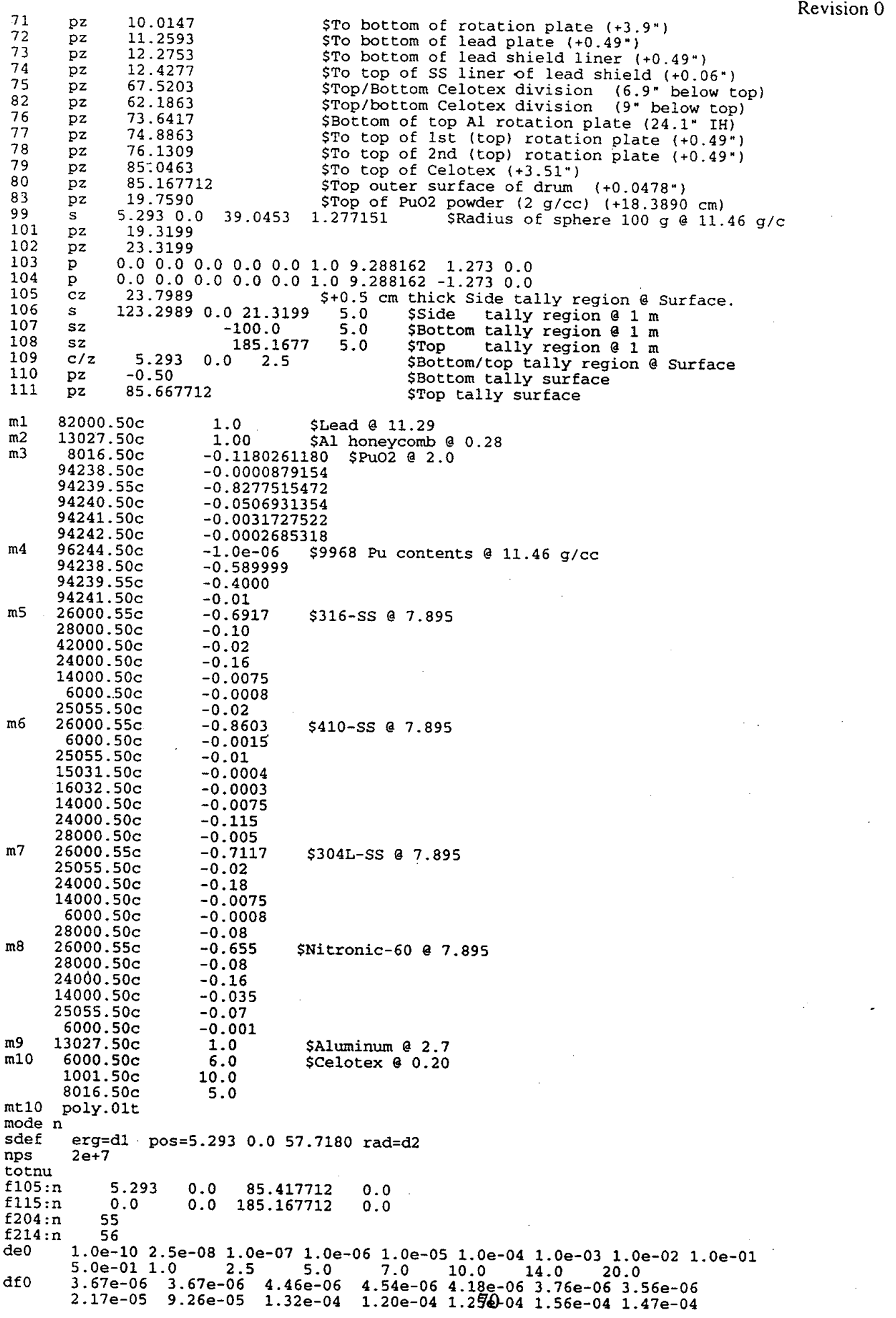

Revision 0 
WSRC-TR-98-00279

Engineered Equipment and Systems Department

Dose Calculation for Pu-238 Oxide Payload

N-CLC-G-00067

in 9968 Shipping Container

WSMSC-98-0207

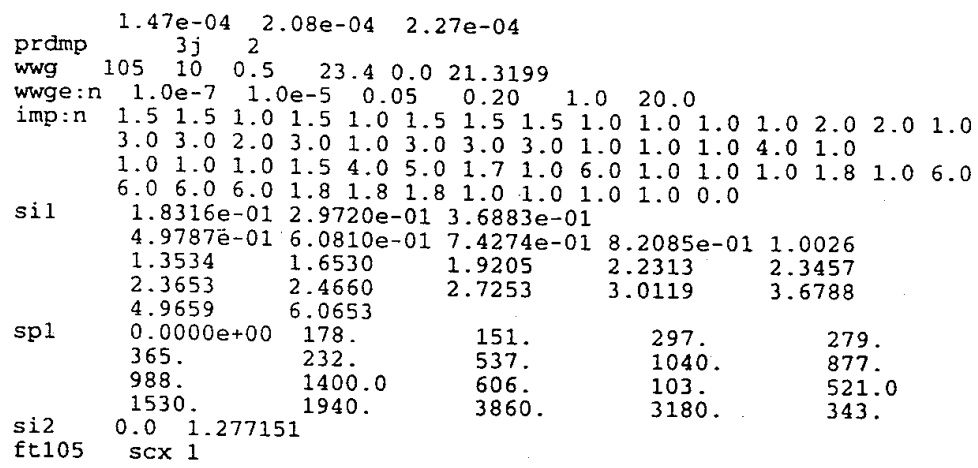

Revision 0 
WSRC-TR-98-00279

Engineered Equipment and Systems Department

Dose Calculation for Pu-238 Oxide Payload

N-CLC-G-00067

in 9968 Shipping Container

WSMSC-98-0207

Revision 0

\section{APPENDIX B}

\section{MCNP Information}

B.1. MCNP Input and Output File Identification

B.2. Renormalization of MCNP Results 


\section{B.1. MCNP Input and Output File Identification:}

Table B.1 shows the job names for the MCNP calculations. All input and output files are stored on the WSMS workstation cluster under /raid1/users/rwebb/9968/hac (for HAC cases) or raidl/users/rwebb/9968/nct (for NCT cases). Input file names are as shown in Table B.1; output files have a.out extension.

It should be noted that for neutron and $(\mathrm{n}, \gamma)$ calculations, the source location/geometry is the same for side and bottom dose receptors, hence only a single calculation (e.g. nnks8 or npks9) was needed to get doses at the side and bottom. Doses at the surface and at a distance of 1 meter were also computed in the same calculation.

In the MCNP calculations, both point and volume tallies were used. Reported values were taken from the point detector tallies. The volume tallies were used as an independent confirmatory mechanism.

\section{TABLE B.1. MCNP File Names}

\begin{tabular}{|c|c|c|c|c|}
\cline { 2 - 5 } \multicolumn{2}{c|}{} & \multicolumn{2}{|c|}{ HAC } & NCT \\
\hline \multirow{3}{*}{ Neutron } & $\begin{array}{c}\text { side } \\
\text { bottom } \\
\text { top }\end{array}$ & \multicolumn{2}{|c|}{$\begin{array}{c}\text { nnks8 } \\
\text { nnks8 } \\
\text { nnkt9 }\end{array}$} & $\begin{array}{c}\text { nnnks1 } \\
\text { nnnks1 } \\
\text { nnnkt1 }\end{array}$ \\
\hline \multirow{4}{*}{ Photon } & $\begin{array}{c}\text { side } \\
\text { bottom } \\
\text { top }\end{array}$ & \multicolumn{2}{|c|}{$\begin{array}{c}\text { npks9 } \\
\text { npks9 } \\
\text { npkt9 }\end{array}$} & $\begin{array}{c}\text { nnpks1 } \\
\text { nnpks1 } \\
\text { nnpkt1 }\end{array}$ \\
\cline { 2 - 5 } & side & $\begin{array}{l}\text { Groups 16-18 } \\
\text { Groups 8-15 }\end{array}$ & $\begin{array}{l}\text { gks2a } \\
\text { gks3a }\end{array}$ & ngks3 \\
\cline { 2 - 5 } & bottom & $\begin{array}{l}\text { Groups 16-18 } \\
\text { Groups 8-15 }\end{array}$ & $\begin{array}{l}\text { gkb2a } \\
\text { gkb3a }\end{array}$ & ngkb3 \\
\cline { 2 - 5 } & top & $\begin{array}{l}\text { Groups 16-18 } \\
\text { Groups 8-15 }\end{array}$ & $\begin{array}{l}\text { gkt2a } \\
\text { gkt3a }\end{array}$ & ngkt3 \\
\hline
\end{tabular}

\section{B.2. Renormalization of MCNP Results}

The MCNP point and volume flux tallies have units of $1 / \mathrm{cm}^{2}$ per starting particle. In the calculations, the flux-to-dose conversion factors from ANS-6.1.1-1977 were used. The conversion factors have units of rem/hr per $1 / \mathrm{cm}^{2}-\mathrm{s}$, which can be restated as rem-cm $\mathrm{cm}^{2}-\mathrm{s}$ per hour. The MCNP tallies therefore have units of rem-s/hr per starting particle. To obtain the dose in $\mathrm{mrem} / \mathrm{hr}$ the MCNP tally value must be multiplied by $1000 \mathrm{mrem} / \mathrm{rem}$ and by the total particle emission rate. The particle emission rate is determined from Table 8 and the number of source groups in the calculation. For example, for a neutron source calculation using neutron Groups $7-25$, the neutron emission rate is 18427 
WSRC-TR-98-00279

Engineered Equipment and Systems Department

Dose Calculation for Pu-238 Oxide Payload

N-CLC-G-00067

in 9968 Shipping Container

WSMSC-98-0207

Revision 0

neutrons/s per gram of actinide (sum of the emission rates for Groups $7-25$ ) multiplied by 100 grams of actinide. Table B.2 shows the normalization factor, the MCNP tally value, and the renormalized value for the different cases. Where calculated, the values for the MCNP volume tallies are also presented and can be compared to the corresponding point detector values. The column labeled "E.R.E. 1-sigma" is the Estimated Relative Error from MCNP - the E.R.E. multiplied by the estimated mean gives the 1-sigma uncertainty.

\section{TABLE B.2. MCNP Tally Results and Normalization Constants}

\begin{tabular}{|c|c|c|c|c|c|c|c|c|c|}
\hline & \multirow{2}{*}{$\begin{array}{l}\text { Calc. } \\
\text { Type }\end{array}$} & \multirow{2}{*}{$\begin{array}{l}\text { Dose Receptor } \\
\text { Location }\end{array}$} & \multirow{2}{*}{$\begin{array}{l}\text { Job } \\
\text { Name }\end{array}$} & \multirow{2}{*}{$\begin{array}{c}\text { Normalization } \\
\text { Constant } \\
(1 / \mathrm{s})\end{array}$} & \multicolumn{3}{|c|}{ POINT DETECTORS } & \multicolumn{2}{|c|}{ VOLUME TALLIES } \\
\hline & & & & & $\begin{array}{c}\text { Unnorm. Mean } \\
\text { (rem-s/h) }\end{array}$ & $\begin{array}{c}\text { E.R.E. } \\
\text { 1-sigma }\end{array}$ & $\begin{array}{c}\text { Mean } \\
(\text { mrem/h) }\end{array}$ & $\begin{array}{c}\text { Normed Mean } \\
(\text { rem-s/h) }\end{array}$ & $\begin{array}{c}\text { E.R.E. } \\
\text { 1-sigma }\end{array}$ \\
\hline \multirow{12}{*}{ HAC } & & side @ $1 \mathrm{~m}$ & & & $1.2403 \mathrm{E}-09$ & 0.0004 & 2.286 & \multirow{6}{*}{\multicolumn{2}{|c|}{ Not Calculated }} \\
\hline & Neutron & bottom@1 m & & $1.842 / 2+49$ & $1.0240 \mathrm{E}-09$ & 0.0004 & 1.887 & & \\
\hline & & top @ $1 \mathrm{~m}$ & nnkt9 & $1.85012 \mathrm{E}+09$ & $3.8261 \mathrm{E}-10$ & 0.0020 & 0.708 & & \\
\hline & & side @ I m & & & $4.0329 \mathrm{E}-12$ & 0.0018 & $7.461 \mathrm{E}-03$ & & \\
\hline & $(n, \gamma)$ & bottom @1 m & npks9 & & $2.7615 \mathrm{E}-12$ & 0.0016 & $5.109 \mathrm{E}-03$ & & \\
\hline & & top @ $1 \mathrm{~m}$ & npkt9 & $1.85012 \mathrm{E}+09$ & $1.0291 \mathrm{E}-12$ & 0.0056 & $1.904 \mathrm{E}-03$ & & \\
\hline & Photon & side @ $1 \mathrm{~m}$ & gks2a & $1.6667 \mathrm{E}+14$ & $1.6882 \mathrm{E}-14$ & 0.0054 & 2.814 & $2.0201 \mathrm{E}-14$ & 0.1437 \\
\hline & Groups & bottom@1 m & gkb2a & $1.6667 \mathrm{E}+14$ & $1.1565 \mathrm{E}-14$ & 0.0067 & 1.928 & $1.1554 \mathrm{E}-14$ & 0.184 \\
\hline & $16-18$ & top @ $1 \mathrm{~m}$ & gkt2a & $1.6667 \mathrm{E}+14$ & $4.7908 \mathrm{E}-18$ & 0.0827 & $7.985 \mathrm{E}-04$ & 0 & 0 \\
\hline & Photon | & side @ $1 \mathrm{~m}$ & gks3a & $1.7815 \mathrm{E}+11$ & $9.3468 \mathrm{E}-12$ & 0.0005 & 1.665 & $9.3238 \mathrm{E}-12$ & 0.0157 \\
\hline & Groups & bottom@1m & gkb3a & $1.7815 \mathrm{E}+11$ & $7.7128 \mathrm{E}-12$ & 0.0006 & 1.374 & $7.7867 \mathrm{E}-12$ & 0.0178 \\
\hline & $8-15$ & top @ $1 \mathrm{~m}$ & gkt3a & $1.7815 \mathrm{E}+11$ & $8.6100 \mathrm{E}-13$ & 0.0255 & 0.1534 & $7.6634 \mathrm{E}-13$ & 0.0672 \\
\hline \multirow{18}{*}{ NCT } & & side @ surface & & & $3.9333 \mathrm{E}-08$ & 0.0037 & 72.479 & $3.8487 \mathrm{E}-08$ & 0.0046 \\
\hline & Neutron & bottom @surface & nnnks l & $1.84270 \mathrm{E}+09$ & $2.9652 \mathrm{E}-08$ & 0.0076 & 54.640 & $2.9036 \mathrm{E}-08$ & 0.0061 \\
\hline & & top @ surface & nnnkt l & $1.84270 \mathrm{E}+09$ & $1.1415 \mathrm{E}-08$ & 0.0037 & 21.034 & 1.1267E-08 & 0.0062 \\
\hline & & side @ surface & & & $9.4295 \mathrm{E}-11$ & 0.0207 & 0.1745 & $8.9378 \mathrm{E}-11$ & 0.0126 \\
\hline & $(\mathrm{n}, \gamma)$ & bottom @ surface & nnpks I & 1. & $1.0536 \mathrm{E}-10$ & 0.0123 & 0.1949 & $1.0196 \mathrm{E}-10$ & 0.0123 \\
\hline & & top @ surface & nnpkt1 & $1.85012 \mathrm{E}+09$ & $3.6887 \mathrm{E}-11$ & 0.0050 & 0.0682 & 3.6965E-11 & 0.0133 \\
\hline & Photon & side @ surface & ngks3 & $1.7815 \mathrm{E}+11$ & $7.0263 E-11$ & 0.0225 & 12.517 & $6.9461 \mathrm{E}-11$ & 0.0070 \\
\hline & Groups & bottom @ surface & ngkb3 & $1.7815 E+11$ & $1.3814 \mathrm{E}-10$ & 0.0087 & 24.610 & $1.3638 \mathrm{E}-10$ & 0.0117 \\
\hline & $8 \cdot 15$ & top @ surface & ngkt3 & $1.7815 E+11$ & $1.3012 \mathrm{E}-11$ & 0.0106 & 2.318 & $1.2911 \mathrm{E}-11$ & 0.0187 \\
\hline & & side@ $1 \mathrm{~m}$ & $\ln$ & & $9.4453 \mathrm{E}-10$ & 0.0004 & 1.740 & $9.6097 \mathrm{E}-10$ & 0.0159 \\
\hline & Neutron & bottom @ $1 \mathrm{~m}$ & nnnksi & 1.84270 & $7.9385 \mathrm{E}-10$ & 0.0005 & 1.463 & $7.8852 \mathrm{E}-10$ & 0.0174 \\
\hline & & top $@ 1 \mathrm{~m}$ & nnnktl & $1.84270 \mathrm{E}+09$ & $4.0836 \mathrm{E}-10$ & 0.0005 & 0.7525 & $4.0239 \mathrm{E}-10$ & 0.0157 \\
\hline & & side @ $1 \mathrm{~m}$ & Dnmolas 1 & 10501050 & $2.1783 \mathrm{E}-12$ & 0.0024 & $4.030 \mathrm{E}-03$ & $2.0909 E-12$ & 0.0456 \\
\hline & $(\mathrm{n}, \gamma)$ & bottom @1 m & nnpks I & $1.85012 \mathrm{E}+09$ & $2.3757 \mathrm{E}-12$ & 0.0042 & $4.395 \mathrm{E}-03$ & $2.5447 \mathrm{E}-12$ & 0.0416 \\
\hline & & top @ $1 \mathrm{~m}$ & nnpkt1 & $1.85012 \mathrm{E}+09$ & $1.0987 \mathrm{E}-12$ & 0.0012 & $2.033 \mathrm{E}-03$ & $1.1180 \mathrm{E}-12$ & 0.0393 \\
\hline & Photon & side @ $1 \mathrm{~m}$ & ngks3 & $1.7815 \mathrm{E}+11$ & $2.3721 \mathrm{E}-12$ & 0.0030 & 0.4226 & $2.1923 \mathrm{E}-12$ & 0.0335 \\
\hline & Groups & bottom @ $1 \mathrm{~m}$ & ngkb3 & $1.7815 E+11$ & $3.9764 \mathrm{E}-12$ & 0.0009 & 0.7084 & $4.1464 \mathrm{E}-12$ & 0.0365 \\
\hline & & top @1 m & ngkt3 & $1.7815 \mathrm{E}+11$ & $6.1568 \mathrm{E}-13$ & 0.0090 & 0.1097 & $5.8826 \mathrm{E}-13$ & 0.0472 \\
\hline
\end{tabular}


WSRC-TR-98-00279

\section{DISTRIBUTION}

H. A. Gunter, 703-F

T. C. Hasty, 235-F

J. B. Schaade, 703-F

J. D. Cohen, 773-A

M. A. Ebra, 773-42A

E. K. Opperman, 773-54A

S. J. Hensel, 773-42A

M. N. Vanalstine, 773-53A

W. M. Massey, 773-54A

STI, 773-51A (4 copies)

Offsite Dist

D. Eckman, DOE-OH

R. Finney, B\&W of Ohio

J. N. Crawford, B\&W of Ohio 